\title{
Cintia Alves
}

Dranaturgija do silèncio

Processo de escrita em colaboração de uma tragédia sem palavras

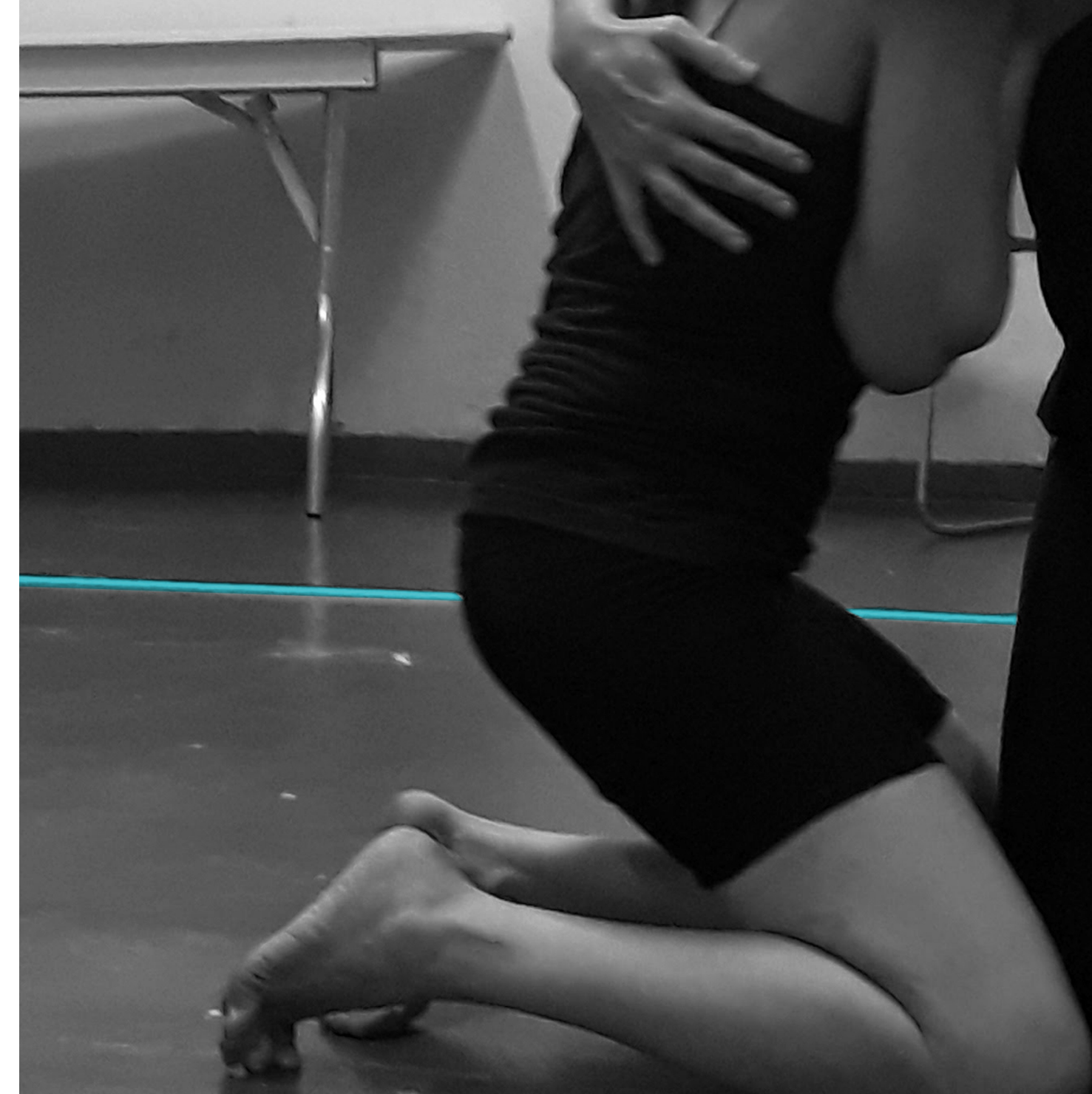

: - Säo Paulo - 2018 


\section{CINTIA ALVES}

Dramaturgia do silêncio

Processo de escrita em colaboração de uma tragédia sem palavras 


\section{CINTIA ALVES}

Dramaturgia do silêncio

Processo de escrita em colaboração de uma tragédia sem palavras

Dissertação apresentada ao Programa de PósGraduação em Artes Cênicas da Universidade de São Paulo para obtenção do título de Mestra.

Área: Pedagogia do Teatro Linha de Pesquisa: Formação do Artista Teatral.

Orientador: Prof. Dr. Eduardo Tessari Coutinho.

São Paulo 
ALVES, C. Dramaturgia do silêncio: processo de escrita em colaboração de uma tragédia sem palavras. 2018. 141 f. Dissertação (Mestrado em Pedagogia do Teatro) - Departamento de Artes Cênicas, Escola de Comunicações e Artes, Universidade de São Paulo, São Paulo, 2018.

Aprovada em:

Banca Examinadora

Prof. Dr.

Instituição:

Julgamento:

Prof. Dr.

Instituição:

Julgamento:

Prof. Dr.

Instituição:

Julgamento: 
À menina que declarou, aos 11 anos,

que iria estudar Artes Cênicas na USP. 


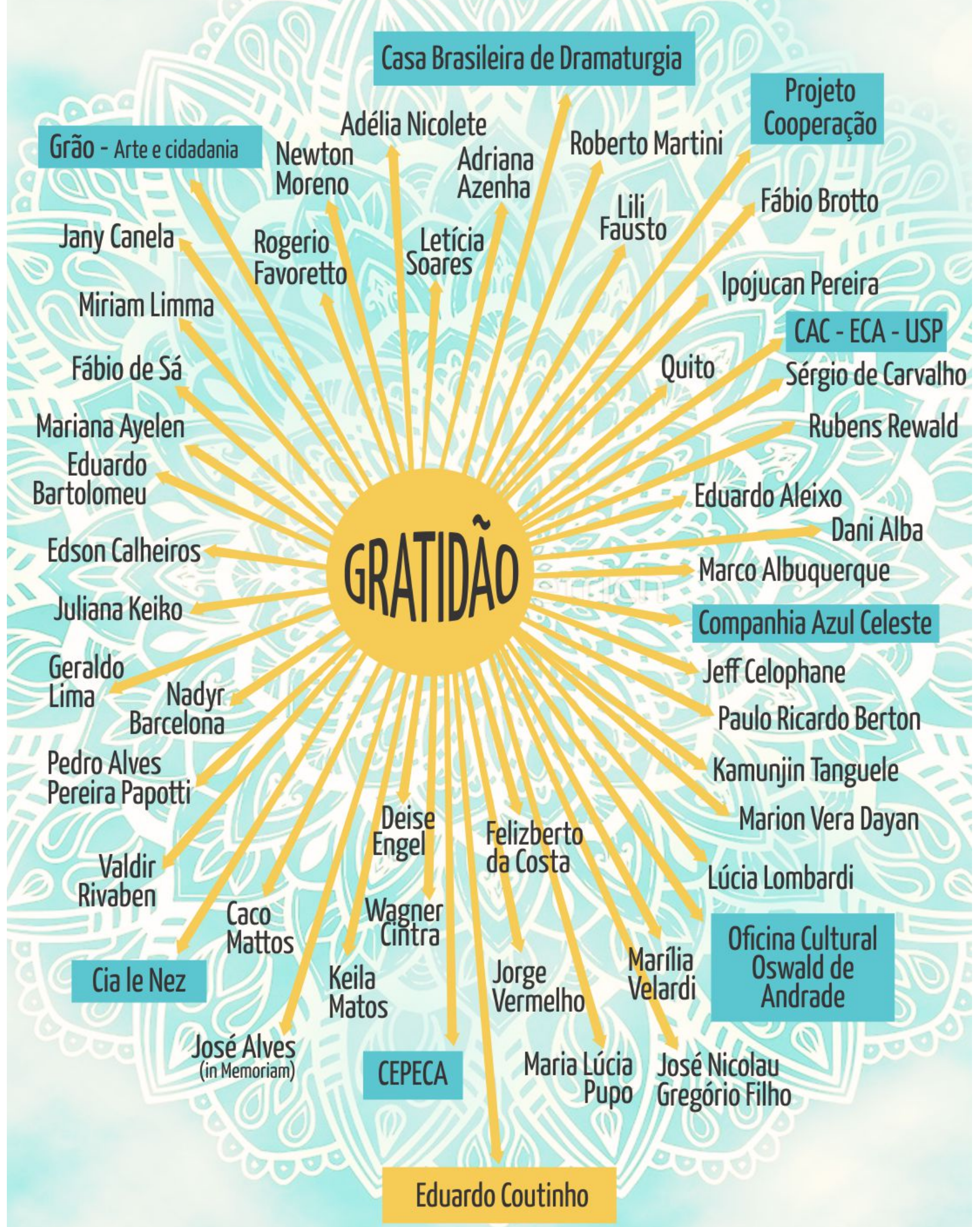




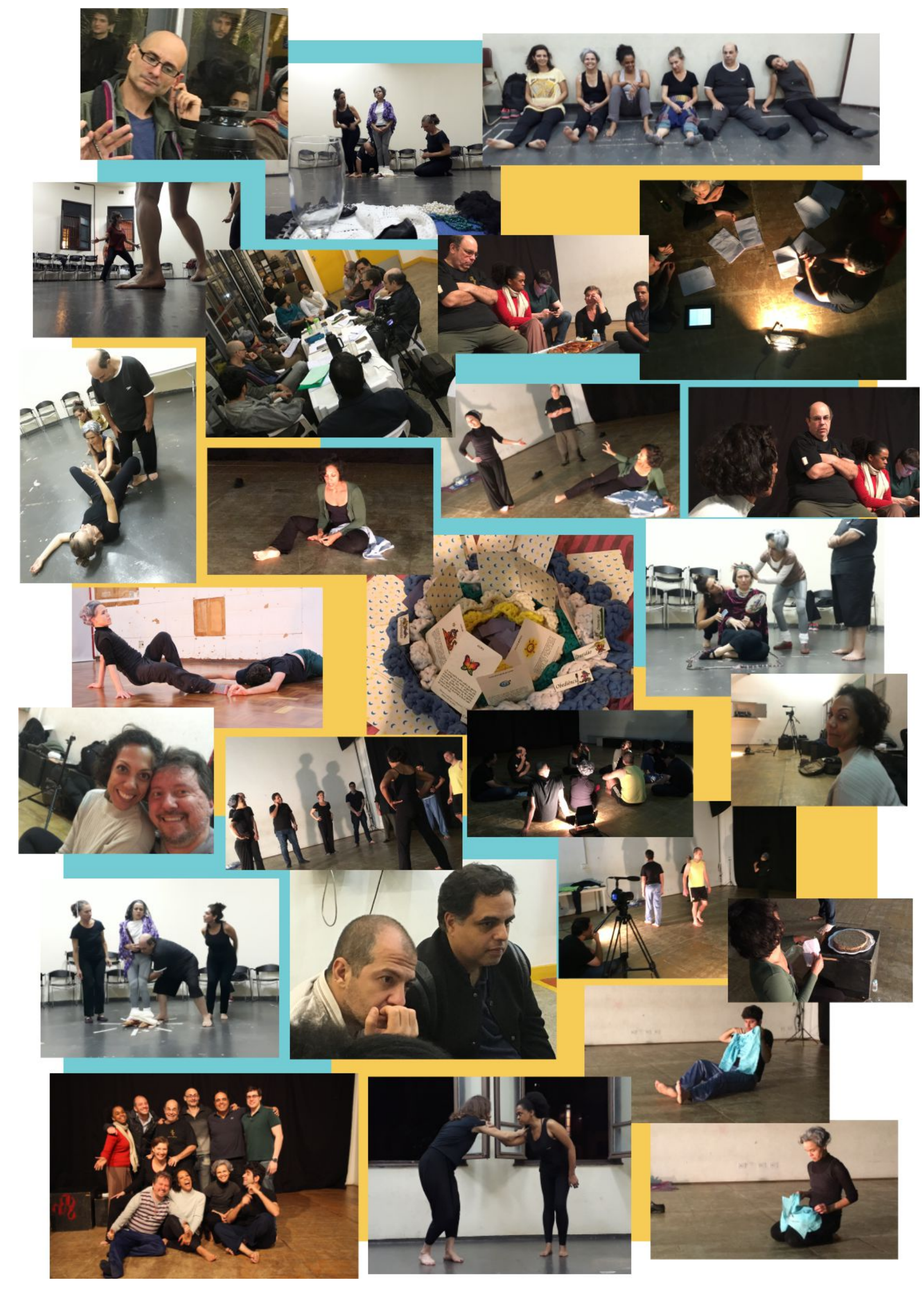


O teatro é necessariamente uma experiência entre pessoas. $O$ tempo de duração de uma peça é tempo de vida e, como tal, deve ser intenso, repleto de pulsação e fluxo entre palavras, sons, ações, imagens, silêncios e pessoas. A permeabilidade de sentidos e o entendimento de que cada elemento que integra uma obra é parte significativa dela e contribui para que sua percepção seja ampla e potente, é o que pode determinar um conceito expandido de dramaturgia. O texto é um aspecto muito importante, mas não é tudo. Há um campo complexo de articulação de linguagem que, bem entendido, pode incluir a palavra, mas que leva em consideração, muitas vezes sem hierarquia, todos os outros elementos que compõem a obra. E é aí que dramaturgia e encenação tornam-se indissociáveis.

Márcio Abreu (VASQUES \& CUNHA, 2016, p. 289) 


\section{RESUMO}

ALVES, C. Dramaturgia do silêncio: processo de escrita em colaboração de uma tragédia sem palavras. 2018. 141 f. Dissertação (Mestrado em Pedagogia do Teatro) - Departamento de Artes Cênicas, Escola de Comunicações e Artes, Universidade de São Paulo, São Paulo, 2018.

O presente projeto se propõe a uma investigação da reescritura de uma obra de constituição dramática retirando-se dela os diálogos ditos pelas personagens e estabelecendo a comunicação por meio da ação física dos atores e atrizes na cena, mantendo-se, contudo, aquilo que a caracteriza como dramática: uma fábula constituída em progressão para que haja tensão, conflito, clímax e desenlace. A esse processo de extração dos diálogos deu-se o nome de "Dramaturgia do Silêncio". É importante ressaltar que a cena silenciosa se serve de outros elementos significativos como cenografia, iluminação, figurino, maquiagem etc, mas o recorte deste estudo centra-se no trabalho do texto corporal do ator e da atriz, a partir dele que se estabelece a dramaturgia. Tratase de um estudo teórico-prático realizado parcialmente em sala de ensaio com um grupo de criadores cênicos em câmbio de funções entre dramaturgos, atores e encenadores por meio de jogos e improvisações. $O$ texto base para esse estudo é Phèdre, de Jean Racine, um dos três grandes representantes do classicismo francês.

Dramaturgia. Poética. Jogo. Criação Colaborativa. 


\section{RESUMÉ}

ALVES, C. Dramaturgie du silence: processus d'écriture en collaboration d'une tragédie sans paroles. 2018141 f. Dissertação (Mestrado em Pedagogia do Teatro) - Departamento de Artes Cênicas, Escola de Comunicações e Artes, Universidade de São Paulo, São Paulo, 2018.

Le projet que nous présentons ici se propose à une investigation de la réecriture d'une oeuvre de constitution dramatique, en enlevant les dialogues proférés par les personnages et établissant la communication au moyen de l'action physique des acteurs et des actrices, mais en maintenant, néanmoins, ce qui la caractérise comme dramatique : une fable constituée en progression pour qu'il y ait de la tension, du conflit, un climax et un dénouement. A ce processus d'extraction des dialogues nous avons donné le nom de " Dramaturgie du Silence". Il est important de souligner que la scène silencieuse se sert d'autres éléments significatifs comme la scénographie, l'éclairage, les costumes, le maquillage, etc. mais le découpage de cette étude se concentre sur le travail corporel des acteurs, à partir duquel s'établit la dramaturgie. II s'agit d'une étude théorique et pratique élaborée surtout en salle de répétitions avec un groupe de créateurs scéniques sur le mode d'un échange de fonctions entre dramaturges, acteurs et metteurs en scène au moyen de jeux et d'improvisations. Le texte de base pour cette étude est la pièce Phèdre de Racine, un des trois grands représentants du classicisme français.

Dramaturgie. Poétique. Jeu. Création collaborative. 


\section{LISTA DE QUADROS}

Quadro1 - Comparativo entre a forma dramática e a forma épica 60

Quadro 2 - Genealogia de Phèdre e Thésée ....................................................71

Quadro 3 - Linhagem de Thésée........................................................................... 72

Quadro 4 - Linhagem Fedra - Creta................................................................... 72

Quadro 5 - Modelo actancial de seis casas, conforme Greimas...........................91

Quadro 6 - Modelo actancial com separação entre os pares. ................................92

Quadro 7 - Modelo actancial com Phédre como sujeito.........................................94

Quadro 8 - Modelo actancial com Hippolyte e Aricie como sujeitos .....................9. 94

Quadro 9 - Sete práticas da pedagogia da cooperação .......................................102

Quadro 10 - Procedimento: o círculo e o centro....................................................103

Quadro 11 - Procedimento: ensinagem cooperativa...........................................107

Quadro 12 - Procedimento: do mais simples para o mais complexo ................110

Quadro 13 - Procedimento: ser mestre-e-aprendiz...........................................121 


\section{LISTA DE FIGURAS}

Figura 1 - Fedra (Adriana Azenha) tem os cabelos arrumados por Enone (Eduardo

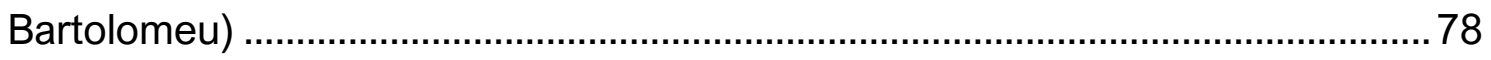

Figura 2 - Fedra (Miriam Lima) é acariciada por Enone (Rogério Favoretto) .....79

Figura 3 - Fedra (Jany Canela) é abraçada por Enone (Adriana Azenha) ..........79

Figura 4 - Enone (Rogério Favoretto) descobre o amor de Fedra (Jany Canela) por Hipólito 83

Figura 5 - Fedra (Adriana Azenha) é flagrada se masturbando com a camisa de Hipólito por Enone (Eduardo Bartolomeu) 84

Figura 6 - Tapete de crochê e Carta dos Anjos para compor o centro do círculo. .106

Figura 7 - Atores no trabalho de aquecimento das articulações do corpo........111 Figura 8 - Adriana Azenha e Miriam Limma ensaiando na sala 5 da Oficina Cultural Oswald de Andrade. 115

Figura 9 - Adriana Azenha e Miriam Limma ensaiando na sala 22 da Oficina Cultural Oswald de Andrade. 115

Figura 10 - Mariana Ayelen e Miriam Limma se preparando para o jogo "Pá".

Figura 11 - Adriana Azenha e Miriam Limma na finalização do jogo "Pá"........118

Figura 12 - Jany Canela improvisando com o objeto cênico camisa..................123

Figura 13 - Dani Alba improvisando com o objeto cênico camisa. .....................123

Figura 14 - Sequência do exercício sobre Fedra (II,5) com Dani Alba e Jany Canela 130 


\section{SUMÁRIO}

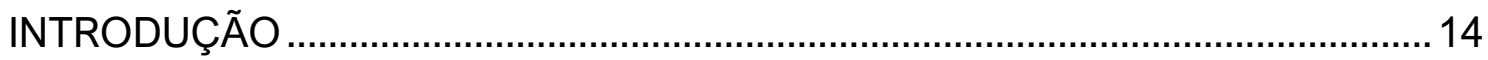

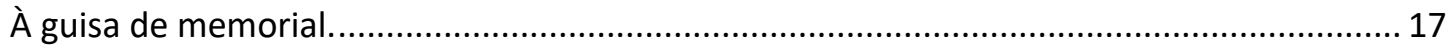

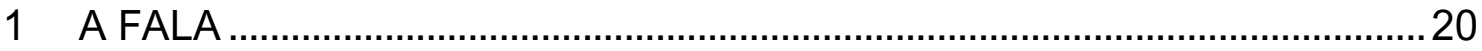

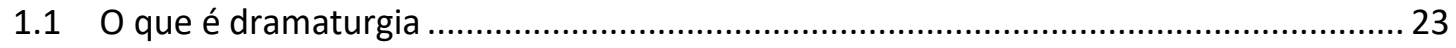

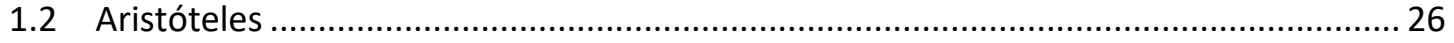

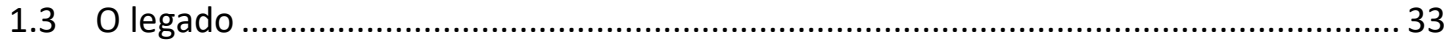

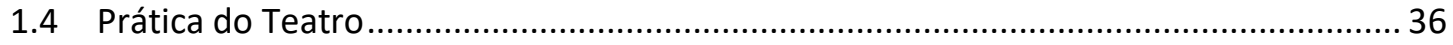

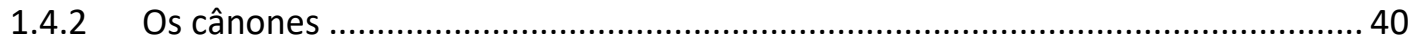

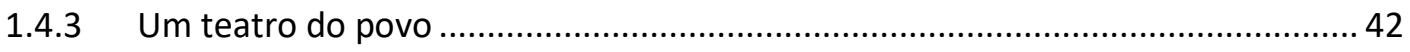

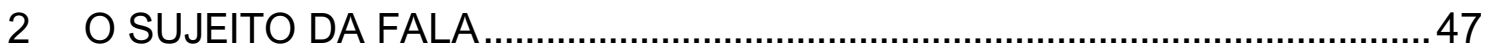

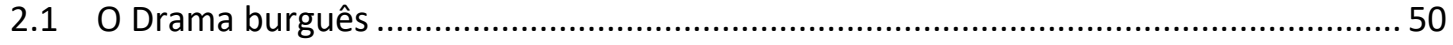

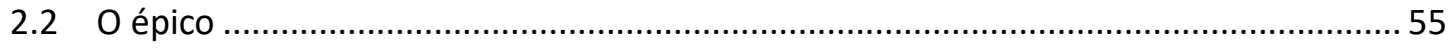

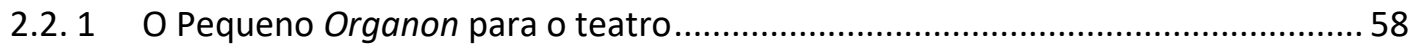

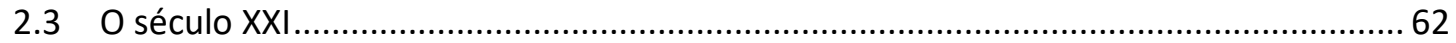

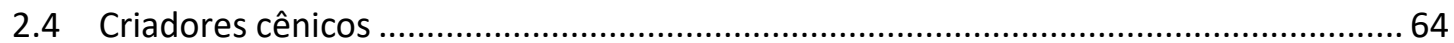

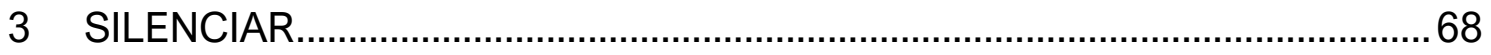

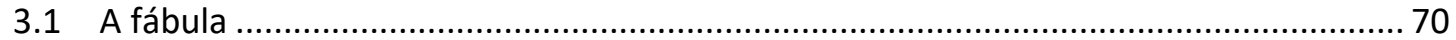

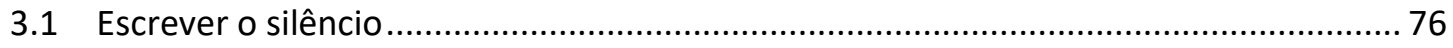

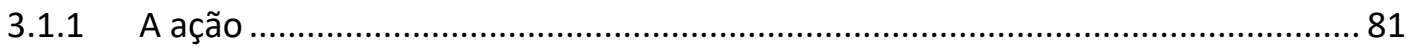

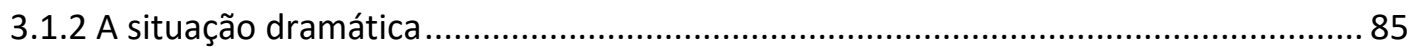

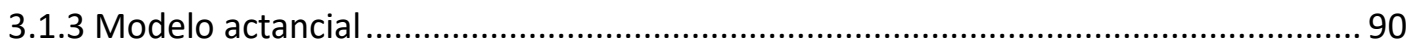

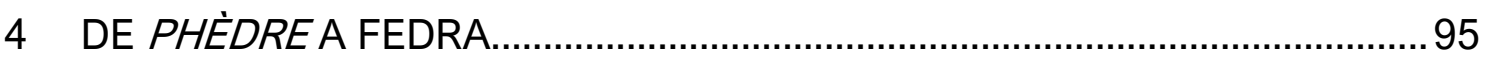

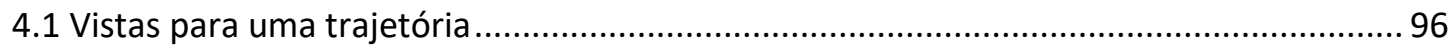

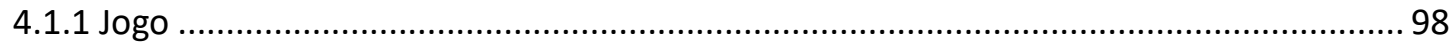

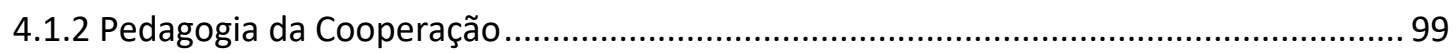

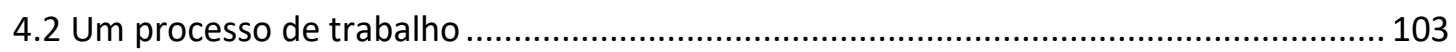

4.2.1 Primeira prática - Fazer COM-TATO (vide Quadro 9) …........................................ 103

4.2.2 Segunda prática - Estabelecer COM-TRATO (vide Quadro 9)................................. 105

4.2.3 Terceira prática - Compartilhar IN-QUIETA-AÇÕES (vide Quadro 9) ........................ 107

4.2.4 Quarta prática - Fortalecer alianças e parcerias (vide Quadro 9) ........................... 109

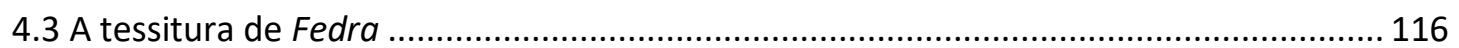

4.3.1 Quinta prática - Reunir soluções COMO-UNS (vide Quadro 9) ............................... 117

4.3.2 Sexta prática realizar soluções COMO-UNS (vide Quadro 9) ................................... 120 
4.3.3 O narrativo.

4.4 Sétima prática - realizar projetos de Cooperação (vide Quadro 9) ................................... 127

CONSIDERAÇÕES FINAIS ............................................................................132 


\section{INTRODUÇÃO}

Esta uma pesquisa teve como ponto de partida reflexões formais a respeito da dramaturgia. Paulatinamente, isso se expandiu e exibiu raízes em uma dimensão histórica, política e social.

A proposta inicial do estudo era observar como a malha de diálogos arquitetados na dramaturgia seria capaz de inspirar uma trama de ações físicas que traduzissem a sua fábula. A reescritura pela "Dramaturgia do Silêncio" darse-ia, portanto, pelo tecido formado nessa composição. Como se tratava de uma proposta de investigação sobre a tradução da palavra por meio da visualidade do texto corporal do ator, constituí um coletivo de artistas cênicos a fim de que a experimentação acontecesse em uma prática visual-espacial.

Mas esse foi apenas o ponto de partida, porque o real objeto de pesquisa foi se desvelando aos poucos, ao longo do processo, à medida que avançavam as experimentações do coletivo com o texto matriz, Phèdre ${ }^{1}$, de Racine, assim como nossas indagações sobre sua constituição. O primeiro movimento foi reconhecer que Phèdre é uma reescritura a partir de Hipólito, de Eurípedes. Hipólito, por sua vez, não é apenas o texto de Eurípedes escrito a partir do mito de Fedra: é também uma reescritura que o poeta fez de si próprio. Assim, nos deparamos com a condição das múltiplas leituras embutidas não apenas em Fedra, mas em nosso processo. E esse caminho foi traçado por meio da percepção crítica de indivíduos inseridos em um contexto coletivo. Essa visão de leitura em camadas também aconteceu durante o estudo das questões formais. Devido à natureza da pesquisa, todo o referencial teórico surgiu em função das necessidades práticas. Nos capítulos que sucedem, apresento um panorama aproximado de como nos deparamos com as diferentes visões.

No primeiro capítulo, em sobrevoo pela Poética de Aristóteles, há uma delicada e determinante questão em relação às várias traduções que aproximaram essa obra das línguas modernas. O presente estudo toma duas

\footnotetext{
${ }^{1}$ Todos os títulos de obras estão grafados de acordo com os exemplares aos quais tive acesso, se traduzidos ou no original.
} 
traduções diferentes para análise; uma para o português lusitano, feita por Ana Maria Valente, e outra para o português brasileiro, feita por Jaime Bruna. Além disso, também figura a análise de Daisi Malhadas a partir da mesma obra. $\mathrm{O}$ interessante é como cada tradução apresenta pequenas disparidades, que, no entanto, podem revelar aspectos essenciais. Essas disparidades também se apresentam em relação à enunciação da dramaturgia e às delimitações que foram sendo criadas para a execução dessa arte, vista e aplicada de modo diverso nos teatros oficiais da França e nos rudimentares palcos montados nas feiras livres do país.

Essas primeiras descobertas impulsionaram um olhar sobre o dado da leitura individual, que é esboçado no segundo capítulo, e que nos levou ao traçado da personagem do dramaturgo ou da dramaturga ao longo da história, ou melhor dizendo, decorrente dos apontamentos de alguns procedimentos dramatúrgicos que nos revelavam a trajetória do poeta dramático em um determinado contexto histórico. A postura individual é determinante não apenas em relação à produção dramatúrgica ou crítica, mas também em relação ao que ela é capaz suscitar à posteridade. E essa leitura posterior só se relaciona com os registros escritos. Nesse aspecto, o texto e não a cena tornam-se o principal objeto de percepção.

Seguindo essa progressão, no terceiro capítulo, na análise de Phèdre, fezse necessário compreender um pouco da perspectiva de Racine, um tanto do seu contexto, como forma de estabelecer um diálogo entre sua obra e nosso momento atual. Algumas ferramentas de análise serviram como apoio na elucidação de questões intrínsecas ao texto.

No quarto capítulo, exponho minha percepção como mediadora desse processo, para proporcionar um ambiente de jogo no qual as individualidades de cada artista cênico tivessem espaço para se colocar. Essa trança resultou em algumas interpretações livres e a leitura particular da obra.

Cabem, ainda, algumas elucidações sobre a redação do presente texto. 
O tom da escrita está relacionado a essa experiência do indivíduo ante o processo, por isso é adotado o relato em primeira pessoa, a fim de delimitar a conjuntura de escolhas poéticas e políticas, elegendo determinadas questões em detrimento de outras, apontando dificuldades e contradições.

Algumas citações diretas estão traduzidas no corpo do texto, enquanto outras estão postas em língua estrangeira, e sua tradução aparece em forma de nota. O que está no corpo do texto é a informação tal qual foi colhida, e as traduções em nota, em sua maioria, são feitas pela relatora. Quando não o são, citou-se a autoria de o autor de quem traduziu. As traduções do francês antigo foram auxiliadas por Marion Vera Dayan. No caso de Phèdre, por exemplo, as referências até o terceiro capítulo são do texto original em francês, mas no quarto capítulo, que se refere à sala de ensaio, são empregadas as traduções de Jenny Klabin Segall e Millôr Fernandes, uma vez que elas foram a base para o trabalho coletivo. $\mathrm{O}$ acesso às obras originais de Racine, D'Aubignac e Bonnassies (sobre as feiras) foi possível pela plataforma Gallica - a biblioteca digital com acesso gratuito da Bibliothèque Nationale de France - e ao projeto de edições gratuitas de obras de domínio público do Amazon.com.

Outra peculiaridade é que são apresentadas duas grafias: Phèdre e Fedra. A primeira se refere ao texto de Racine, a segunda é toda e qualquer leitura feita a partir do texto. Isso fez com que, em alguns momentos, nos quais os dois pontos de vista se entrelaçam, a grafia se tornasse Phèdre-Fedra.

Quando há referência à dramaturgia, até o século XVIII é usada a terminologia poeta dramático ou dramaturgo, no entanto, quando se faz referência à contemporaneidade, em que há pluralidade de gênero no ofício, o termo é flexionado nos dois gêneros - dramaturgos e dramaturgas, artistas cênicos e artistas cênicas. 
À guisa de memorial.

Iniciei a carreira artística como bailarina, com algumas incursões como coreografa, o que fez com que corpos em movimento fossem minha principal orientação.

Minha primeira graduação, em Direção Teatral, aconteceu quase por um acaso, uma vez que a Universidade de São Paulo, onde me graduei, fica na cidade de São Paulo, e a graduação em dança era oferecida na Unicamp, em Campinas. A mudança de cidade significava abandonar um cenário que se apresentava muito sólido naquele momento, por isso acabei escolhendo a cidade e não propriamente o curso. Nos primeiros anos de graduação, eu estudava a então chamada Técnica do Movimento Consciente, de Klauss Vianna, que depois passou a se chamar Técnica Klauss Vianna. Nesse período, fui aluna do Mestre Klauss, de Rainer Vianna e de Neide Neves, minha principal formadora. A técnica trabalha com as percepções dos vetores que constituem o movimento, o que acaba por possibilitar uma percepção de composição e relação com o próprio corpo, com outros corpos e com o espaço. A partir dessa formação, comecei a apoiar os trabalhos de direção de ator dos amigos e amigas da faculdade, como preparadora corporal. Esse movimento me levou à direção cênica. A dramaturgia surgiu pela minha necessidade de propor na cena histórias que estavam relacionadas à minha experiência e leitura de mundo.

Durante o período em que cursei a universidade - e nos vinte anos subsequentes - estabeleci uma prática como diretora constituída por essa trança entre o corpo, a encenação e a dramaturgia. $O$ trabalho sempre partia de um pretexto que podia ser um texto teatral, literário ou apenas uma ideia, que, em contato com o trabalho corporal dos atores, de jogos e improvisações, estabelecia a tecelagem do espetáculo. Como referência para minhas pesquisas não acadêmicas estava o trabalho de Bertolt Brecht, Peter Brook, Eugênio Barba, Luís Otávio Burnier, Jacques Lecoq e outros nomes que haviam atribuído às suas práticas uma pedagogia. Uniram-se a eles autores dedicados à dramaturgia, com especial destaque a Étienne Souriau, que tem sido meu guia desde 1992, quando me foi apresentado por um mestre do qual sinto muita saudade, Eudinyr Fraga. 
Como disse, segui esse caminho e esses mestres por 20 anos, com a permanente intenção de voltar à academia para aprofundar minhas pesquisas, mas nunca tinha me deparado com algo significativo que me conduzisse a isso.

Em 2013, recebi da Companhia Azul Celeste uma incumbência bastante peculiar: criar uma dramaturgia "sem palavras" a partir do texto Fim de Jogo, de Samuel Beckett. A dramaturgia seria feita nos moldes do meu trabalho: eu criaria jogos que girariam em trono do texto original e, a partir daí, constituiria a reescritura. A direção ficou ao cargo de Georgette Fadel. Jorge Vermelho, que concebeu o projeto, funcionava como um guardião do trabalho, uma vez que os ensaios conjuntos entre mim, Georgette e o elenco foram bastante esparsos. $\mathrm{O}$ resultado foi o espetáculo Mundomudo, meu primeiro grande mergulho no silêncio.

Já tinha pesquisado o silêncio com meus alunos do Laboratório de Dramaturgia do Teatro Safra e em outras oficinas e grupos de pesquisa pelos quais tinha passado - tinha, inclusive, usado o texto Atos sem Palavras, de Beckett, como meio de investigação da construção de ação dramática -, no entanto, criar um texto silencioso, partindo de outro texto teatral com a profundidade dos diálogos apontados por Clov e Ham, foi um dos maiores desafios da minha carreira.

Trabalhar com o silêncio tem algumas implicações, sobretudo dentro de um panorama no qual a fala não seria substituída pela pantomima, mas as ações deveriam ser construídas e encadeadas de forma a comunicar concretamente paixões, expectativas e conflitos das personagens.

Concluí o texto, rodamos o Brasil, mas a experiência do trabalho continuava sendo "digerida". Na minha prática com teatro, nunca abri espaço para a investigação do processo, para a análise de quais ferramentas, meios e estratégias foram usadas na "carpintaria"; eu simplesmente faço. Mas, nesse momento, senti a necessidade de refletir sobre o modo como a construção da dramaturgia aconteceu. 
Ao mesmo tempo, eu tinha começado a pesquisar teatro com pessoas Surdas $^{2}$, o que me obrigava a transformar toda e qualquer palavra em ação, para um elenco que nem falava nem ouvia, e essas perguntas, que já me inquietavam, ganharam uma proporção indizível.

Não se tratava mais de construir um novo trabalho, de fazer uma nova peça; agora era uma questão investigativa do fazer teatral: como construir uma dramaturgia do silêncio a partir de um texto que o negue? A pergunta, na verdade, é "Isso é possível?"

Este estudo é um amálgama entre o texto e a cena, porque não trata apenas de descobrir dramaturgicamente a melhor maneira de gerar didascálias, mas sobretudo de verificar cenicamente o potencial comunicativo das ações subjacentes aos diálogos.

O objetivo foi realizar uma pesquisa estética, esmiuçar ao máximo o texto matriz, Phèdre de Racine, para reconhecer-Ihe os meandros. No entanto, não há estética sem política e, ao investigar Phèdre, necessariamente me deparei com questões significativas relativas à nossa existência neste início de século XXI e neste país.

O corpo não se relaciona apenas com o espaço do palco, uma caixa preta ou não, com ou sem elementos cenográficos, frontal ou panorâmica; ele é antes um corpo que se relaciona com o presente, com o seu processo histórico e com tudo o que representa.

Não há espaços para falsidades no silêncio, tudo que é visível é percebido, a busca é reconhecer, tecer e tramar a partir disso.

\footnotetext{
${ }^{2}$ A grafia Surdo ou Surda, com inicial maiúscula, refere-se à identidade de um indivíduo inserido dentro de uma cultura. A grafia "surdo" ou "surda" representa a patologia. (SOLOMON, 2013, p. 67)
} 
"Drama quer dizer ação. O teatro é o lugar onde uma ação é levada à sua consecução por corpos em movimento diante de corpos vivos a mobilizar." (RANCIĖRE, 2012, p. 9)

Percebo a dramaturgia não apenas como o arranjo das palavras no papel, mas também como organização de algo que se materializa no tempo e no espaço. Considerando que todos os esforços da dramaturgia tenham como objetivo a encenação, a ideia é que nesse processo utilizem-se quaisquer recursos para escrever ações no espaço. Nesse contexto, a palavra é um recurso possível, mas não o único.

Segundo Rykner (2004), Racine é o poeta dramático que mais se ateve aos preceitos de François Hèdelin, abade de D'Aubignac, seu contemporâneo e teórico francês designado pelo Cardeal de Richelieu para proceder um estudo que daria origem a parte dos cânones do teatro clássico com o sugestivo nome de Pratique du Théâtre: oeuvre très-nécessaire à tous ceux qui veulent s'appliquer à la composition des poëmes dramatiques ${ }^{3}$ (AUBIGNAC F. H., 1657). D'Aubignac versa sobre aspectos bem amplos da composição dramática, mas apenas um é particularmente importante nesse contexto, que é o que se refere ao fato de a poesia dramática ter seu processo comunicativo fundamentado na fala das personagens sem que possa haver didascálias indicativas de ações:

[...] na Poesia Dramática só existem personagens introduzidas pelo Poeta, as quais falam, sem que ele participe, e em toda a Ação Teatral também ele não estará presente se os Actores forem, em verdade, aqueles que representam, não precisando do seu ministério para se explicarem nem para agirem. (AUBIGNAC ${ }^{4}$, F.H.,1657, p. 45 apud in RYKNER, 2004, p. 27)

Perscrutar a partir dessa postulação de impossibilidade tornou-se, no mínimo, desafiador. A exemplo do que promove o criador cênico italiano Carmelo Bene, referido por Deleuze (DELEUZE, 2010), a proposta é realizar um ensaio

\footnotetext{
3 "Prática do teatro: um trabalho muito necessário para todos os que querem se aplicar à composição de poemas dramáticos" (tradução minha)

${ }^{4}$ AUBIGNAC, François Hedelin, Abade de, La pratique du théâtre, Paris, 1715.
} 
crítico, mas o objetivo não é "criticar" nada, antes é penetrar a estrutura para possibilitar uma aproximação com sua essência. Deleuze se refere a uma leitura de Romeu e Julieta, feita por Bene, na qual ele "amputa Romeu, ele neutraliza Romeu na peça originária” (DELEUZE, 2010, p. 28), e, dessa forma observa como todo o restante da estrutura se comporta sem esse elemento que é, aparentemente, essencial. Tal como Bene, a presente análise será feita pela amputação de um dos elementos essenciais da peça originária; no caso, a palavra falada pelas personagens. Phèdre, de Racine, será o texto germinal desse estudo.

Partir de um ícone do classicismo francês teve como objetivo compreender os meandros dessa composição teatral cunhada como dramática, portanto, antes do manejo das ferramentas eleitas para este estudo, que são os corpos no espaço, há que se compreender quais são as regras e os procedimentos empregados para que o "dispositivo" tenha seu perfeito emprego. Para tanto, é necessário esclarecer a expressão "dispositivo", terminologia emprestada de Foucault:

Ce que j'essaie de répeter sous ce nom, c'est premièrement un ensemble resolument hétérogène comportant des discours, des institutions, des aménagements architecturaux, des décisions reglementaires, des lois, des mésures administratives, des énoncés scientifiques, des propositions philosophiques, morales, philantropiques, bref: du dit aussi bien que du non-dit, voilà les elements du dispositif. Le dispositif lui-même c'est le reseau qu'on établit entre ces éléments [...] [...] par dispositif, j'entends une sorte - disons - de formation qui à un moment donné a eu pour fonction majeure de repondre à une urgence. Le dispositif a doné une fonction stratégique dominante... Le dispositif est toujours inscrit dans un jeu de pouvoir [...] [...] Ce que j'appelle dispositif est un cas beaucoup plus général que l'epistème. Ou que plutôt l'épistème c'est un dispositif spécialment discursif, à la différence du dispositif qui est lui, discursif et non discursif. (FOUCAULT, M., 1973, p. $3^{5}$ Dits e ecrits AGAMBEN, 2005, p. $9)^{6}$

\footnotetext{
${ }^{5}$ FOUCAULT, M. Dits e ecrits: (1954-1988), tome III: 1976-1979. Paris, Gallimard, 1973.

${ }^{6} \mathrm{O}$ que estou tentando repetir sob este nome é, antes de mais nada, um conjunto definitivamente heterogêneo de discursos, instituições, desenvolvimentos arquitetônicos, decisões regulatórias, leis, medidas administrativas, declarações científicas, proposições filosóficas, morais, filantrópicas, em suma: tanto o dito como o não dito, eis os elementos do dispositivo. O dispositivo em si é a rede estabelecida entre esses elementos [...]. Por dispositivo, eu ouço um tipo - digamos - de treinamento que, em dado momento, teve a principal função de responder a uma emergência. $O$ dispositivo, portanto, tem uma função estratégica dominante ... Está sempre inscrito em um jogo de poder [...] [...] O que eu chamo de dispositivo é um caso muito mais geral do que a episteme. Ou melhor, que a episteme é um dispositivo especialmente discursivo, ao contrário do dispositivo, que é discursivo e não discursivo.
} 
Assim, no momento da apresentação do texto de Racine, também foi necessária a identificação do cenário histórico e cultural na qual ele estava inserido, bem como a compreensão dos dispositivos que a suscitaram: a formação do Antigo Regime e consolidação do Rei Louis XIV na França. Essa necessidade também traduz um aspecto da dramaturgia como uma composição que acontece no tempo, no espaço e no momento histórico.

Tendo estabelecido essa referência, fica claro que o estudo de Phèdre não está apenas ligado à parte declarada no texto de Racine, mas compreende também a relação entre a existência desse texto e o "caldo nutritivo" que o possibilitou. Não é um estudo histórico, mas antes um mergulho para reconhecimento do ambiente. Racine tinha seus motivos para escrever a Phèdre que escreveu, ele estava influenciado por uma complexidade estética e política, assim como os artistas criadores que compuseram esta pesquisa. Estabelecer diálogo entre lá e cá, por antagonismo, aproximação, negação, crítica ou qualquer possibilidade que se interponha é inerente à reescrita.

A propósito da terminologia reescrita - já referida duas vezes, que trata da recriação a partir de um texto pré-existente -, mais adiante dedicaremos tempo para reflexão sobre a complexidade da sua execução.

É preciso, também, esclarecer a complexidade do que, nos dias de hoje, significa a palavra dramaturgia. O que inicialmente era uma sequência de palavras escritas no papel para serem repetidas pelos atores no local de representação - o que poderia ser tanto uma praça pública como um canapé estrategicamente posicionado na sala de algum nobre ou abastado -, passou a ter uma profusão de sentidos que pode, inclusive, excluir o uso da palavra. $O$ movimento da história do teatro nos apontou que dramaturgia, numa análise simples, trata da composição. No Dicionário de Teatro de Patrice Pavis na página 113, o verbete dramaturgia traz a seguinte informação: "do grego dramaturgia, compor um drama." É uma ideia bastante propícia para a compreensão do sentido geral da palavra, entendendo-se que compor é juntar, combinar, arranjar. Então, tem-se que dramaturgia é a arte de juntar "coisas" para fazer um drama. Isso suscita duas perguntas: Quais são essas coisas? e O que é fazer um drama? 
Aparentemente, a reflexão aqui proposta trata de compreender esse movimento teatral que se dá sem a utilização da palavra, no entanto, ela é antes a criação de certa consciência dos muitos códigos dos quais o teatro é composto e de como esse evento, que é espacial visual, estabelece conexões, mesmo que não tenham uma decodificação racional.

\subsection{0 que é dramaturgia}

Não sou uma pessoa que se iluda facilmente e realmente acredite que haja condições de responder à pergunta $O$ que é dramaturgia. Não com uma única e paradigmática resposta. Não tenho essa ilusão nem pretensão. Farei antes apontamentos de caminhos possíveis e que foram trilhados pelo coletivo de artistas criadores durante a pesquisa. Para o bem da coletividade, há a necessidade de que se alinhem certas ideias, mesmo que defectivas, a fim de conquistar certa fluência na comunicação. O que estou chamando de defecção, no caso, é uma visão um tanto parcial do que vem a ser o fenômeno dramatúrgico, e essa parcialidade está embasada no nosso texto referência. A estética da dramaturgia raciniana advém de certos cânones que povoaram o classicismo francês do XVII, portanto o olhar sobre a dramaturgia neste estudo tem esse norteador.

Mas é importante salientar que qualquer concepção dramatúrgica é sempre um tanto parcial, porque calcada numa determinada visão de mundo e este estudo considera um recorte específico, não a dramaturgia como um todo.

Tendo isso em mente, talvez seja mais interessante fazer a pergunta de outra forma: Que "coisas" são da competência da dramaturgia? A tentativa de resposta a essa pergunta perpassa alguns séculos e, além da compreensão de quais são os elementos constitutivos da dramaturgia, inclui a busca de uma maneira modelar de organização desses elementos.

Inicio por compreender o que vem a ser drama - do grego ação -, segundo o Dicionário de Pavis (2015, p. 109): "Num sentido geral, o drama é o poema dramático, o texto escrito para diferentes papéis e de acordo com uma ação conflituosa." 
Quero selecionar os elementos que constroem essa definição, a fim de compreendê-la também em suas subjacências: texto escrito, diferentes papéis e ação conflituosa. Dessa forma, a dramaturgia trata de palavras escritas para a construção de personagens variadas que tenham algum tipo de problema entre si. Esse problema pode ser um obstáculo comum ou um embate.

A visão que Eugênio Barba apresenta em A Arte Secreta do Ator(2012, p. 66) da mesma terminologia afirma:

“O que está relacionado ao 'texto' (à tessitura) do espetáculo pode ser definido como dramaturgia, ou seja, drama-ergon, o trabalho das ações no espetáculo. Já o modo como as ações trabalham constitui a trama.

O que é interessante notar nessas duas acepções é que a primeira estabelece a dramaturgia com uma constituição modelar de "diferentes papéis e ação conflituosa", e a segunda focaliza no "trabalho das ações no espetáculo" e qualifica como trama a forma como isso acontece. Segundo Barba, ação conflituosa não faz parte da definição de dramaturgia, mas sim de um desenho possível de trama. Ele segue discorrendo sobre o que vem a ser a ação e amplia significativamente esse conceito, abarcando o texto, o jogo entre os atores, luz, cenografia, sons, as relações entre as personagens, enfim, considera como ação toda a complexidade do que vem a ser o evento do teatro (BARBA \& SAVARESE, 2012, p. 66). Tendo essa referência tão ampla do sentido de ação, pensar que ela é necessariamente conflituosa muitas vezes impossibilita a existência da própria dramaturgia. Isso não significa que a acepção de Pavis esteja equivocada e que a de Barba esteja certa ou vice e versa: cada um percebe uma diferente visão estética do fenômeno e por isso manifesta a particularidade na escolha do olhar.

Essa pesquisa abarca as duas acepções, tanto a de Pavis quanto a de Barba. No decorrer dos encontros, ensaios e leituras, ambas de entrelaçaram. Agora darei continuidade à pesquisa sobre a terminologia dramaturgia. $\mathrm{O}$ Dicionário de Teatro. um pouco mais adiante, na página 110, Pavis (2015) referese à acepção de outro termo que, no contexto deste estudo, dialoga com o sentido que o autor chama de dramático:

"O dramático é um princípio de construção do texto dramático e da representação teatral que dá conta da tensão das cenas e dos episódios da fábula rumo ao desenlace (catástrofe ou solução cômica), 
e que sugere que o espectador é cativado pela ação. $O$ teatro dramático [...] é o da dramaturgia clássica, do realismo e do naturalismo, da peça bem-feita."

Pavis não está sozinho quando postula que o conflito faz parte da essência da dramaturgia. Ele acompanha séculos de história do teatro, sobretudo de um teatro que considera o texto como um evento separado da sua representação, como se aquele subjugasse este, como se aquele fosse o cerne e este o derivado. Essa é a definição da chamada dramática rigorosa, e sua origem remonta aos primeiros estudos acerca do teatro no ocidente, aos gregos que começaram a pensar na poética, em uma maneira exemplar de estruturação do texto. Aristóteles foi responsável pelos primeiros conceitos que temos de dramaturgia no ocidente e produziu um legado que permanece até a atualidade, como afirma Carlson (1997, p. 13):

"A Poética não é apenas uma obra significativa na tradição como seus conceitos principais e linhas de argumentação influenciaram persistentemente o desenvolvimento da teoria ao longo dos séculos. A teoria do teatro ocidental, em essência, começa em Aristóteles."

Os postulados de Aristóteles foram se solidificando ao longo do tempo e, no século XVII, na França, ganhou uma rigidez dogmática. O autor anteriormente citado, François Hèdelin, abade D’Aubignac, é um dos que se propõe a escrever uma poética própria, a sua $A$ Prática do Teatro, com um subtítulo que merece ser mencionado, uma vez que exprime exatamente qual a sua dimensão ou ao que se propunha: "obra extremamente necessária àquele que pretende se dedicar à composição de poemas dramáticos, que os recita em público, ou que tem prazer em ver as representações", ou seja, é um manual para dramaturgos, atores e também para o público. Nela, ele propõe quais são as "coisas" que compõem o drama e configura o que vem a ser uma espécie de Bíblia para o drama burguês. O paradigma proposto por D’Aubignac não era uníssono, havia vários autores que se opunham à maneira dele se referir à composição da poesia dramática. Ele parte de Aristóteles, usa os elementos aristotélicos, mas os combina de modo a estabelecer uma estrutura que se comunique diretamente com as necessidades do Antigo Regime que se solidificava na França. 
Um século mais tarde, na mesma França, Denis Diderot escreverá seu Discurso sobre o Poema Dramático na crença de que o teatro tem o enorme potencial de difusão das ideias iluministas, fortalecendo a Revolução que se avizinhava e contribuiria para a derrocada do Antigo Regime ${ }^{7}$. (DIDEROT, 2005)

Observando brevemente esses quatro momentos - a contemporaneidade de Barba, o estudo acadêmico de Pavis, os séculos XVII e XVIII na França - e compreendendo que a história se desloca não apenas no tempo, mas também no espaço, pode-se ter um laivo das transformações do que se entendia como dramaturgia nesse longo percurso da Grécia, desde aproximadamente o século IV a.C, até França do XVIII, e como isso pode dialogar com a profusão na qual estamos mergulhados hoje.

Esse pequeno recorte é apenas para mostrar que a conceituação de dramaturgia é mutável, porém fundante, e acaba por se confundir com o que vem a ser o próprio teatro. Mas não o é. Como essa é a matéria da qual esta pesquisa se constitui, é absolutamente necessário que haja claro entendimento não do conceito, mas de como ele foi compreendido pelo coletivo de artistas ao longo das investigações feitas para a construção de uma dramaturgia do silêncio.

Comecemos por Aristóteles.

\subsection{Aristóteles}

A Poética de Aristóteles, como já foi dito, é a primeira grande referência para a compreensão dos postulados do que vem a ser a poesia dramática no Ocidente. Essa sim, é leitura obrigatória para qualquer um que se proponha a estudar teatro, seja como dramaturgo, diretor, ator ou mesmo espectador com apreciação estética mais apurada do que é/foi o acontecimento teatral no

70 Antigo Regime - ou Velho Regime - é o termo usado para tratar as aristocráticas monarquias absolutas da Europa. Segundo Hobsbawm, a França era "a mais poderosa, e sob vários aspectos a mais típica" representação desse regime de governo e de sua estrutura estamental, tendo como consequência uma forma mais aguda de conflito entre a estrutura oficial e as novas forças sociais ascendentes, que acabaram por desembocar na revolução de 1789. (2003, p. 83-103) 
ocidente. No entanto, há questões conflituosas no que diz respeito à transmissão, organização e até compreensão de alguns conceitos dessa obra fundamental.

Aristóteles procura organizar os elementos que constituem o belo na arte poética, dividindo essa arte em quatro categorias: a epopeia, a tragédia, a comédia e a poesia ditirâmbica (ARISTÓTELES, 2008). Para ele, o cerne do belo está na arte da mimesis. Aliás, essa é uma ideia que perpassa toda a obra, sendo o conceito fundamental de toda atividade poética e também onde começam os quiproquós.

A palavra mimesis ordinariamente é traduzida como imitação, no entanto, a professora Dra. Daisi Malhadas e alguns outros estudiosos propõem a tradução de mimesis por representação e não imitação, como normalmente se encontra, baseada nas reflexões de Dupont-Roc e Lallot:

[...] a MIMESIS é "poética", isto é, CRIADORA. Não EX-NIHILO8: há uma matéria prima que é o homem dotado de caráter, capaz de ação e de paixão, preso numa série de acontecimentos. Estes dados, o poeta não imita como se fizesse um decalque [...] o poeta, enquanto MIMETÉs, constrói [...] uma "história" (MYTHOS) com seus actantes funcionais. Ele só imita para representar os objetos que lhe servem de modelos [...] apagam-se por trás do objeto [...] história representada [...]. MIMESIS designa esse movimento que parte de objetos preexistentes e chega a um artefato poético, e a arte poética é, segundo Aristóteles, a arte dessa passagem. (Dupont-Roc \& Lallot p. $20^{9}$ apud MALHADAS, 2003 p. 18)

Patrice Pavis (2015, p. 241), no verbete referente a mimesis, incorpora as duas acepções - "a mimese é a imitação ou a representação de uma coisa" -, no entanto, ele segue usando apenas imitação como palavra sinônima.

Incluo aqui, apenas como curiosidade, e também para dar mais uma perspectiva de que a conceituação sobre a arte poética é sempre parcial, a visão de Platão, contemporâneo e mestre de Aristóteles, no livro X de $A$ República (2016), que abjura o conceito de mimesis. "as imitações poéticas são nocivas ao espírito dos ouvintes" (PLATÃO, p. 390).

Seguindo na estrutura da Poética, o drama surge no capítulo 6:

A tragédia é a imitação de uma acção elevada e completa, dotada de extensão, numa linguagem embelezada por formas diferentes em cada uma das suas partes, que se serve da acção e não da narração e que,

\footnotetext{
${ }^{8}$ Do latim, do nada.

${ }^{9}$ DUPONT-ROC, R. e LALLOT, J. Aristote, La Poétique, Text, Traduction, notes. Paris, Éditions du Seuil, 1980.
} 
por meio da compaixão e do temor, provoca a purificação de tais paixões. (ARISTÓTELES, 2008, p. 47)

Mais adiante, Aristóteles esmiúça esses elementos:

É necessário, portanto, que toda a tragédia tenha seis partes pelas quais é definida. São elas: enredo, caracteres, elocução, pensamento, espectáculo e música. Duas partes constituem os meios de imitar; uma parte, o modo; três os objectos da imitação; e, para além disto, nada mais existe. (ARISTÓTELES, 2008, p. 48)

Jaime Bruna (2014, p. 25) na tradução para o português brasileiro, emprega os seguintes termos: fábula, caracteres, falas, ideias, espetáculo e canto. Ao longo dessa dissertação, ora usarei a terminologia tal qual a tradução de Valente, ora a cunhada por Bruna, ora as duas juntas, optando pelo que suscitar maior clareza.

Aristóteles prossegue e estabelece uma hierarquia entre os elementos:

O enredo é, pois, o princípio e como que a alma da tragédia e em segundo lugar vêm, então, os caracteres (é algo semelhante ao que se vê na pintura: se alguém trabalhasse com as mais belas tintas, todas misturadas, não agradaria tanto como se fizesse o esboço de uma imagem). A tragédia é a imitação de uma acção e, através desta, principalmente dos homens que actuam. Em terceiro lugar, está o pensamento: consiste em ser capaz de exprimir o que é possível e apropriado. (ARISTÓTELES, 2008, p. 50)

O enredo/fábula, a história a se contar, é o princípio da tragédia, em torno do qual acontece a imitação ou representação das ações elevadas. Fica claro que, em Aristóteles, o enredo é aquilo que organiza a fruição. É necessário que haja uma história racionalmente identificável para que haja a apreciação estética: "Como a estrutura da tragédia mais bela tem de ser complexa e não simples, ela deve consistir na imitação de fatos inspiradores de temor e pena." (ARISTÓTELES, HORÁCIO, \& LONGINO, 2014, p. 31), essa é a ideia de khathársis que Daisi Malhadas (2003, p. 26) traduz como terror e piedade, e Ana Maria Valente (2008, p. 63) propõe "temor e compaixão": "O temor e a compaixão podem, realmente, ser despertados pelo espectáculo e também pela própria estruturação dos acontecimentos, o que é preferivel e próprio de um poeta superior."

O enredo, para produzir esse efeito, deve ser dividido em três partes: peripécia, reconhecimento e patético, conceitos cujas definições seguem abaixo. 


\section{Peripécia}

"É, como foi dito, a mudança dos acontecimentos para o seu reverso, mas isto, como costumamos dizer, de acordo com o princípio da verossimilhança e da necessidade." (ARISTÓTELES, 2008, p. 57).

A ideia de peripécia é também uma das bases da constituição de um bom roteiro dentro do paradigma do cinema hollywoodiano, que não se furta a afirmar que bebe dos preceitos aristotélicos. O nome dessa reviravolta nos acontecimentos, para Syd Field (1995, pp. 96-111), é plot (virada), e Mckee (2006, p. 183$)^{10}$ nomina como incidente incitante", que "desarranja completamente o equilíbrio de forças na vida do protagonista" (2006, p. 183). ${ }^{11}$

\section{Reconhecimento}

"Reconhecimento, como o nome indica, é a passagem da ignorância para o conhecimento, para a amizade ou para o ódio entre aqueles que estão destinados à felicidade ou à infelicidade." (ARISTÓTELES, 2008, p. 57). É quando acontece a "tomada de consciência" da personagem e ela se dá conta de sua sorte ou malogro. O melodrama é um gênero que se farta desse recurso quando faz, por exemplo, um sem número de casais de amantes se reconhecerem como irmãos. Segundo Aristóteles (2008), essa seria a boa poesia dramática, uma vez que o melhor reconhecimento é o que ocorre juntamente com a peripécia.

\section{Patético}

"Consiste numa ação que produz destruição ou sofrimento, como mortes em cena, dores cruciantes ferimentos e ocorrências desse gênero" (ARISTÓTELES, HORÁCIO, \& LONGINO, 2014, p. 31)

Até aqui, Aristóteles fala sobre os elementos constitutivos das ações dramáticas. São elementos constitutivos do enredo/fábula que incidem

\footnotetext{
10 Syd Field e Robert Mckee são roteiristas e responsáveis pela escrita de "poéticas" para o cinema.

${ }^{11}$ Apresento as referências que o cinema de hollywood faz a Aristóteles com a finalidade de mostrar o quanto a sua Poética continua influenciando a estruturação da composição dramática, mesmo passados aproximados 2500 anos. A nossa maneira de contar e ouvir histórias não se distancia tanto da maneira dos gregos do século VIII a.C.
} 
diretamente nas personagens - protagonistas ou de forma a impactar os protagonistas. A partir deste momento, ele discorre como os elementos devem ser a orientação geral para a construção do enredo/fábula. Inicia pelo conceito de princípio, meio e fim:

Princípio é aquilo que, em si mesmo, não sucede necessariamente a outra coisa, mas depois do qual aparece naturalmente algo que existe ou virá a existir. Pelo contrário, fim é aquilo que aparece depois de outra coisa, necessariamente ou na maior parte dos casos, e a que não se segue nada. Meio é aquilo que é antecedido por um e seguido pelo outro. Portanto, é necessário que os enredos bem estruturados não comecem nem acabem ao acaso, mas sim apliquem os princípios anteriormente expostos. (ARISTÓTELES, 2008, p. 51)

Essa noção deve-se ao fato de Aristóteles caracterizar a tragédia como a representação de uma ação elevada e completa. Pode parecer uma conceituação muito rudimentar, no entanto, é necessário lembrar que se trata de uma obra escrita no século IV a.C., que inaugura o pensamento sobre a arte de escrever e cujos objetos de representação tinham parâmetros muito claros, alinhados com a mitologia e com a tradição. A história de um herói trágico não podia ficar inconclusa, era preciso que houvesse uma apresentação de suas dádivas e maldições (início), como essas dádivas e maldições o impingiriam necessariamente para uma situação problema (meio) e como seria solucionada essa situação-problema, normalmente de uma forma ruim, com morte ou condenação, afinal estamos falando de tragédia (fim). Para Aristóteles, não era possível a inversão ou exclusão desses elementos.

O segundo aspecto proposto é ter uma extensão condizente com os pressupostos da fábula:

Para dar uma definição em termos genéricos, o limite conveniente da extensão é que esta seja tal que reúna, de acordo com o princípio da verossimilhança e da necessidade, a sequência dos acontecimentos, mudando da infelicidade para a felicidade e vice-versa. (ARISTÓTELES, 2008, p. 52)

Aristóteles define aquilo que chama de "certa extensão" seguindo o que considerava boas práticas na dramaturgia da época: a representação da ação deve durar o suficiente para que a fábula seja contada de modo que o herói tenha tempo, dentro da obra, de sofrer um processo de transformação claramente 
explicitado. Não se devem pular etapas, inclusive como forma de garantia do começo, meio e fim citado anteriormente.

Aristóteles passa, então, a apresentar o que chama de unidade de ação. Para isso, emprega um exemplo bastante claro para explicitar a que se refere quando trata dessa questão: a Odisseia, de Homero. Esse poema épico, transmitido por tradição oral, por meio dos Aedos ${ }^{12}$, tem origem provável no século VIII a.C. e, possivelmente, é a segunda grande narrativa da literatura ocidental. Narra a história do retorno do herói Odisseu (ou Ulisses, na mitologia romana) à Ítaca, após dez anos de luta na Guerra de Troia. O que Aristóteles aponta é que, na narrativa dessa fábula, todos as ações ou acontecimentos propostos estão conectados ao traslado, às dificuldades e implicações desse retorno.

Ao compor a Odisseia, não narrou tudo o que aconteceu a Ulisses como, por exemplo, que ele foi ferido no Parnaso e que fingiu estar louco na assembleia, acontecimentos entre os quais não existia qualquer ligação necessária ou aparente. Pelo contrário, compôs a Odisseia e igualmente a llíada centradas numa acção una, como nós o entendemos. (ARISTÓTELES, 2008, p. 53)

Aristóteles propõe a construção de um todo coeso, em que todas as partes sejam itens indissociáveis do que constitui o enredo, de tal forma que o ato de supressão de uma das partes prejudique o entendimento do enredo: "Realmente aquilo cuja presença ou ausência passa despercebida não é parte de um todo." (ARISTÓTELES, 2008, p. 53)

O conceito de verossimilhança vem a seguir.

Aristóteles aponta, nesse momento, um dos aspectos mais importantes que irá perpassar a base fundamental de toda a poesia dramática. Não importa se o enredo é ficcional ou documental, se os acontecimentos e personagens são reais ou inventados, é preciso que seja verossímil.

Pavis (2015, p. 428) traz um verbete sobre esse tema:

Para a dramaturgia clássica, a verossimilhança é aquilo que, nas ações, personagens, representações, parece verdadeiro para o público, tanto no plano das ações, como na maneira de representá-las no palco. A verossimilhança é um conceito que está ligado à recepção do espectador, mas que impõe ao dramaturgo inventar uma fábula e motivações que produzirão o efeito e a ilusão da verdade.

\footnotetext{
${ }^{12}$ Contadores de história na Grécia antiga.
} 
Esse é um conceito que pode se apresentar controverso, mas que é fundamental. Aristóteles diz que para a boa imitação/representação de uma ação é necessário que ela seja construída de forma que seja crível para o espectador.

É importante, aqui, lembrar em que Aristóteles se baseia para escrever a sua Poética, o que ele está assistindo e ouvindo para fazer todos esses apontamentos. São as tragédias, de Ésquilo, Sófocles, Eurípedes e outros (cujas obras não resistiram ao tempo e/ou ainda não foram descobertas), e as comédias de Aristófanes (e outros), além dos ditirambos, epopeias, entre outras formas fabulares. Podemos supor que ele tenha ouvido alguém contar, em uma praça, que o herói Ulisses lutou e venceu Lestrigões, que eram gigantes antropófagos, e Cíclopes, gigantes imortais com um único olho no meio da testa. E tudo isso era absolutamente verossímil.

Robert Mckee (2006, p. 63), define verossimilhança de uma maneira muito clara, que ele chama de realidade consistente:

REALIDADES CONSISTENTES são ambientes ficcionais que estabelecem modos de interação entre as personagens e seu mundo, mantidos consistentemente ao longo da narrativa para explicitar seu significado. (maiúsculas do autor)

Para Aristóteles o poeta não é um historiador: seu objetivo é relatar o que "poderia" acontecer e criar condições tais - por meio do encadeamento das ações - que tudo pareça crível ao espectador. Isso era válido dentro de um contexto histórico que pressupunha a existência de seres mitológicos convivendo com humanos, portanto, é bastante razoável considerar verossímil que um herói de guerra lute com um Lestrigão. A mitologia era o grande dispositivo formador da identidade daquilo que conhecemos como Grécia, e a verossimilhança estava associada a esse "caldo cultural" no qual os gregos estavam mergulhados.

O terceiro aspecto abordado é quanto às características do herói trágico. Gosto da maneira como Augusto Boal (2008, p. 73) define, no capítulo intitulado Pequeno Dicionário de Palavras Simples, os elementos do herói aristotélico, que passo a apresentar resumidamente aqui.

HERÓI TRÁGICO - No início era o coro, mas quando Thespis inventa a função de protagonista, ocorre uma verdadeira rebelião. No entanto, o coro também era a voz da massa, uma voz que emergia do povo, sem diferenciação e, aos poucos, 
o protagonista/herói passou a representar a aristocracia. Ele também se torna a própria voz da aristocracia à medida que é ela que torna o acontecimento teatral financeiramente possível.

ETHOS - As atitudes do herói são divididas em dois aspectos complementares: ethos, a ação, e dianóia, o pensamento que determina a ação. Esses dois aspectos devem caminhar junto às leis que controlam a coletividade, mas, para que aconteça a peripécia, é preciso que o herói cometa uma única falha na qual ethos e dianóia colidam com o sistema coletivo. Uma única ação precisa furar essa lei, essa única ação determina uma falha irreparável.

HARMATIA $^{13}$ - Conhecida como falha trágica. É a única impureza de caráter da personagem, portanto, a única que deve ser destruída para que o ethos individual se alinhe ao ethos social. Nesse confronto de tendências - sociedade x indivíduo - está situado o conflito.

EMPATIA - Não há uma referência explícita à empatia na Poética de Aristóteles, mas Boal a coloca como elemento de aproximação entre o público e a representação. Todo o sistema descrito por Aristóteles, para ter uma apropriação trágica, deve obedecer a um desenho de forma que o herói transite da felicidade ao infortúnio por uma falha intrínseca, pré-determinada pelos deuses, que o leva a um ethos sem dianóia.

\subsection{O legado}

A Poética é uma obra reduzida e escrita de maneira fragmentada; além disso, não apresenta uma sequência claramente causal. Devido a isso, existem teorias sobre ela seria formada por apontamentos de aula e não composta para a matéria final de um livro, como nos revela Carlson (1997, p. 14):

Embora a Poética de Aristóteles seja universalmente acatada na tradição crítica ocidental, quase todos os tópicos dessa obra seminal suscitaram opiniões divergentes. De vez que o texto grego original se perdeu as versões modernas baseiam-se fundamentalmente num manuscrito do século XII suplementado por uma versão inferior do século XIII ou XIV, mais uma tradução árabe do século X.

Há passagens obscuras nas três versões, e o estilo, em geral, é tão elíptico que os estudiosos chegaram à conclusão de que o manuscrito

\footnotetext{
${ }^{13}$ A grafia que Boal emprega é harmatia não foi encontrada em outras traduções.
} 
original era constituído de uma série de apontamentos de classe, ou então se destinava a circular privativamente entre os discípulos já familiarizados com as lições de Aristóteles. Em anos recentes, especulou-se que algumas partes da Poética seriam, não da lavra de Aristóteles, mas de comentários tardios.

No prefácio da tradução de Ana Maria Valente, a professora Maria Helena da Rocha Pereira apresenta a cronologia das sucessivas traduções que possibilitaram que a obra chegasse aos nossos tempos de forma um tanto transversa:

\begin{abstract}
Certamente conhecida e preservada em Bizâncio, o primeiro texto de que há notícia é, contudo, uma versão siríaca, feita talvez no final do séc. IX, versão da qual, aliás, se conhece apenas parte do capítulo 6 . Na primeira metade do séc. $X$, terá sido traduzida para árabe por Abu Bisr, juntando-se assim ao chamado "Aristotelianismo islâmico", que, paradoxalmente, viria a ser uma via fundamental de difusão do saber grego no Ocidente europeu. Neste mesmo contexto cabe uma referência ao comentário que Ihe fez Averróis no séc. XII, comentário esse que viria a ser traduzido para latim por Hermannus Alemannus, em 1256. Por outro lado, em 1278, surge nova versão latina, desta vez feita a partir do grego, por Guilherme de Moerbecke, mas que só em 1930 veio a ser redescoberta. (ARISTÓTELES, 2008, p. 5)
\end{abstract}

É importante apontar que cada tradutor está mergulhado no caldo de sua própria cultura e que, portanto, a Poética elaborada por Aristóteles serve, muitas vezes, como dispositivo para reflexão das formas de narrativa em diferentes contextos.

Carlson (1997, p. 30) apresenta alguns aspectos que chamam atenção com relação às particularidades dos comentários de Averróis, um deles é uma abordagem moralizadora:

De vez que os imitadores e criadores de similitudes desejavam, por meio de sua arte, impelir as pessoas a determinadas escolhas e desencorajá-las de outras, tinham de tratar assuntos que, ao ser representados, sugeriam virtudes ou vícios. ${ }^{14}$

Essas traduções atenderam, portanto, a um contexto, como afirma ainda Carlson (1997, p. 31):

A Poética penetrou no pensamento crítico medieval, mas não devemos lançar sobre os ombros do erudito árabe ou de seu fiel tradutor latino toda a carga das interpretações errôneas que caracterizam boa parte da crítica subsequente. Ao contrário, a obra de Averróis foi logo aceita

${ }^{14} \mathrm{E}$ em outro trecho, o autor observa que "nada mais que o encorajamento do que é correto e a rejeição do que é vil" e aponta para o distanciamento do conceito teatral de tragédia: o poeta talentoso "não precisa melhorar sua reputação recorrendo a auxílios extrínsecos como gesticulação dramática e expressões faciais." (CARLSON, 1997, p. 31) 
justamente por harmonizar-se tão bem com as atitudes críticas já perfilhadas.

Há uma miríade de traduções, leituras, críticas e comentários da Poética que adentram a Idade Média e seguem pelo Renascimento afora. $O$ objetivo aqui não é apresentar todas as traduções e seus respectivos percursos, mas refletir sobre a profusão de possibilidades de "Poéticas Aristotélicas" que foram lidas ao longo da história. Esse movimento acontece por uma necessidade de parametrização do discurso. Aristóteles estabelece não apenas uma estrutura de reflexão, mas possibilita um legado para a fixação de um conjunto de regras das quais o poeta tinha que se servir a fim de ser considerado como tal. Isso adquire uma formatação tão sentenciosa que temas apenas sugeridos em Aristóteles reaparecem, por meio dos seus tradutores e/ou críticos, com parâmetros metrificáveis. Cito apenas alguns exemplos articulados durante o Renascimento e apresentados no quarto capítulo de Teorias do Teatro, de Carlson (1997): Pietro Pomponazzi afirma que as fábulas são "inverdades a fim de que possamos chegar à verdade" como forma de instruir as multidões (p. 35); Robortello diz que o objetivo da mimesis é o deleite (p. 36); Girardi sugere, à luz do apontamento de Aristóteles quanto à extensão do enredo, que a comédia deva ter três horas e a tragédia quatro horas de duração (p. 39). Em 1570, surge o primeiro estudo crítico sobre Aristóteles, publicado em uma língua europeia moderna, o italiano, que vem a ser Poetica d'Aristotele vulgarizzata e sposta, de Ludovico Castelvetro. Nessa obra, o autor muitas vezes critica Aristóteles e preocupa-se com o público. É ele que cria as duas famosas unidades de tempo e de lugar, afirmando que a apresentação tem que durar no máximo 12 horas, a ação deve corresponder a esse tempo e ocorrer em um só lugar, a fim de ser crível para o espectador (pp. 44-47). Sobre isso, há um breve comentário da professora Maria Helena da Rocha Pereira:

[...] e esta a que se tornou responsável pela chamada "Lei das três unidades" (de acção, de tempo e de lugar), ao proclamá-las erradamente - preceito fundamental a observar na composição de uma tragédia. Volvida em lei inviolável durante o Renascimento, e o Neoclassicismo, será Lessing um dos primeiros a considerar que só o texto relativo à unidade de acção era determinante. (ARISTÓTELES, 2008, p. 7) 
Cabe aqui um breve parêntesis. Quando comecei a estudar teatro, no final dos anos 1980, lembro-me de ouvir alguns de meus colegas aludirem à tal lei das três unidades como sendo um postulado de Aristóteles. Naquele momento da História, qualquer um, que ambicionasse fazer teatro, tinha que conhecer dois grandes nomes: Stanislavski era obrigatório, e Aristóteles se situava mais como uma espécie de depuramento. Quando decidi fazer minha graduação em teatro, em 1990, adquiri uma edição da tradução da Poética feita por Jaime Bruna (2014) para começar a me preparar para a prova de aptidão do vestibular. Apesar de ser eu muito jovem, por ser a linguagem dessa tradução muito fluida e em forma de apontamentos, não tive grande dificuldade em reconhecer a unidade de ação tal qual apresento nesta dissertação. Mas voltei várias vezes à obra, procurando pelas outras duas (tempo e espaço). Acreditava que estavam elípticas em alguma citação ou referência do autor. Finalmente, em 1992, a Professora Dra. Elza Cunha de Vincenzo revelou o que era aparentemente um enigma: não existia a lei das três unidades em Aristóteles, essa era uma invenção de Castelvetro e outros estudiosos da época.

A iniciativa de Castelvetro inspira e estimula o surgimento de Poéticas e manuais de procedimento para os "bons poetas" pela Europa, dentre as quais encontra-se a obra de D’Aubignac, Pratique du Théâtre.

\subsection{Prática do Teatro}

Pratique du Théâtre: oeuvre très-nécessaire à tous ceux qui veulent s'appliquer à la composition des poëmes dramatiques (AUBIGNAC F. H., 1657) foi escrita no auge das grandes discussões sobre as boas práticas para poetas dramáticos e apresenta-se claramente como um manual para o teatro.

Essa movimentação no sentido de estudar os gregos na Europa recebe uma propulsão enorme com a queda de Constantinopla, capital do Império Bizantino ou Império Romano do Oriente. Como demonstra Margot Bertholt, em sua História Mundial do Teatro (2014), o oriente havia se tornado o centro de estudos da cultura grega, no momento da divisão feita pelo imperador Diocleciano. A língua grega foi parcialmente aceita como idioma oficial. No 
momento da queda, "milhares de eruditos e letrados bizantinos, em sua fuga para Oeste, carregaram seus mais preciosos tesouros, os manuscritos da Antiguidade." (BERTHOLT, 2014, p. 269). Aldos Manutius, em Veneza, inaugura uma prensa e inicia a longa série dos Clássicos Aldinos, entre eles, a Poética de Aristóteles.

Como já foi dito, não se sabe ao certo se esses manuscritos trazidos nas axilas dos eruditos bizantinos eram exatamente de Aristóteles. Tenho especial apreço por esse imbróglio, porque em qualquer momento que alguém se proponha a estudar dramaturgia no ocidente, há que se deparar com Aristóteles, mas o fato é que Aristóteles é uma verdade desestabilizada, como em Jorge Luis Borges $^{15}$.

Na França do século XVII, a Poética tornou-se assunto obrigatório nos círculos intelectuais, e o centro do debate, segundo Bertholt, eram as três unidades, uma vez que a de ação ficava muito clara, mas não havia muito consenso sobre as outras duas: "questão do tempo que o dramaturgo pode conceder à ação dramática e a do lugar da cena é discutida com grande minúcia na Pratique du Théâtre."(BERTHOLT, 2014, p. 344)

Os próprios autores investem nessa construção de um modelo, conforme lemos em Pavis (2015, p. 113):

\begin{abstract}
Até o período clássico, a dramaturgia, amiúde elaborada pelos próprios autores (cf. os Discursos de CORNEILLE e a Dramaturgia de Hamburgo, de LESSING), tinha por meta descobrir regras, ou até mesmo receitas, para compor uma peça e compilar para outros dramaturgos as normas de composição (ex.: Poética, de ARISTÓTELES; Prática do Teatro, de D’AUBGNAC).
\end{abstract}

Numa primeira leitura, essa parece ser uma discussão fútil, de intelectuais, mas isso tinha um objetivo estratégico. Na França do século XVII, a arte tem um importante papel de constituição do poder simbólico do rei Louis XIV, portanto o teatro oficial não tinha função de entretenimento, antes era um potente veículo ideológico. Peter Burke, em seu estudo A fabricação do rei (2009) mostra o empenho em se promover uma imagem mitológica do rei. Com esse intento, o monarca promove uma série de ações de institucionalização da arte. Esse

\footnotetext{
15 Jorge Luis Borges (1899-1886) foi um escritor argentino com uma grande produção e, parte dela, em que cita fontes históricas, segundos seus biógrafos, pode ter sido inventada.
} 
movimento acontece nas artes plásticas que, a exemplo dos imperadores romanos, produzem uma quantia substancial de imagens visuais do rei, sempre em ambientes e posturas que o dignifiquem, mas também acontece na poesia, com odes e epopeias em estilo elevado, até os sermões nas igrejas, que constituíam veículo de elevação da figura do Rei. Louis XIV foi embalado com essa aura de divindade desde a sua gestação. Como havia certa tensão no ar sobre a impossibilidade do rei Louis XIII e a rainha Ana da Áustria gerarem herdeiros, quando foi concebido, ele recebeu o estigma de "presente divino", e isso se estendeu ao longo da sua infância, sobretudo com a morte precoce de seu pai, o que acabou por erigi-lo à condição de rei aos cinco anos.

É importante observar que, no restante da Europa, sobretudo na Inglaterra e Holanda, começava, na mesma época em que Louis XIV iniciava seu reinado na França (1654), um movimento de derrocada das monarquias absolutistas e ascensão da burguesia. No entanto, na França, o absolutismo ganhava cada vez mais força, como demonstra Burke, na página 52 (2009): a fronda 16 "pode ser definida como um conflito entre duas concepções de monarquia: a limitada versus a 'absoluta'". Na primeira concepção, o rei era "limitado" pelas leis do reino, que eram guardadas pelo Parlamento de Paris; na segunda, os poderes do monarca eram ilimitados, com a possibilidade de ele, inclusive, determinar quais indivíduos tinham ou não direito à lei. Nesse momento, no entanto, o poder não era divino, não estava acima das leis da natureza. A coroação de Louis XIV aconteceu pouco após a derrota da Fronda. Nas páginas 53 e 54, Burke (2009) descreve esse ritual de coroação, que remontava à Idade Média de Louis VII, como uma sagração do rei, atribuindo a ele uma aura de "messias". E aqui ele faz uma observação muito precisa sobre o olhar que deve nos conduzir nesse acontecimento: "O que o historiador precisa descobrir não é tanto "o que realmente aconteceu', mas o que aconteceu na interpretação da gente da época" (BURKE, 2009, p. 54). E, para a gente da época, houve duas interpretações distintas: a corte próxima entendeu que Louis XIV fora ungido como um Cristo, enquanto a burguesia, que timidamente começava a despontar em Paris,

${ }^{16}$ Do francês fronde ou funda, que era o artefato usado pelo povo para destruir, entre outras coisas, o vidro das janelas. 
observava aquilo como justificativa simbólica para a manutenção do Antigo Regime, o que de fato aconteceu.

Como esta não é uma pesquisa sobre a História da França, vou direto ao ponto a que isso tudo nos leva: o Cardeal Richelieu, assessor do rei e habilidoso administrador do capital cultural, que, no momento, se esmerava para construir a imagem divina de Louis XIV e, com isso, consolidar o poder simbólico do absolutismo na França. Ele administra as academias reais - de arte, pintura, poesia, etc - com a função explícita de constituir órgãos de apropriação de arte e cultura pelo rei. Esse é o momento da fundação d' "A Sociedade dos Cinco Autores", formada pelos cinco "maiores escritores da França" - entre eles Corneille - que tinha por objetivo investigar em seus poemas dramáticos os paradigmas propostos por D'Aubignac. Richelieu encarregou pessoalmente esses homens de escrever um conjunto de peças de acordo com um tema dado. Acreditava-se, então, que os pressupostos oriundos de Aristóteles tinham um caráter didático e de educação moral e, com os devidos ajustes feitos por D'Aubignac, o teatro tornaria-se o principal meio para o trafegar da ideologia absolutista, dando, inclusive aos nobres, noções de comportamento e, sobretudo, de estamento social.

Esse movimento torna o rei o principal mecenas, e estar a seu serviço representou a possibilidade de ascensão de vários jovens intelectuais oriundos do povo, entre eles Molière e Racine. 


\subsubsection{Os cânones}

Quando me propus a compreender o contexto cultural no qual Phèdre está mergulhada, inevitavelmente me deparei com D'Aubignac, porque ele é, ao lado de La Mesnardière ${ }^{17}$, um dos grandes teóricos de teatro do classicismo francês, e o responsável por "investigar e experimentar as regras teóricas em trabalho conjunto" com a Sociedade dos Cinco Autores (BERTHOLT, 2014, p. 344).

A obra de D'Aubignac apresenta-se como um manual preciso de conduta dramatúrgica, abordando muitos aspectos da atividade de escrever para o teatro. Ele parte da Poética, analisa sobretudo textos gregos e romanos, tanto tragédias como comédias, e compõe delimitações muito precisas para a poesia dramática. No entanto, o caminho que me fez chegar a D'Aubignac começou pela tese de doutorado de Arnaud Rykner, O Reverso do Teatro - Dramaturgia do Silêncio da idade clássica a Maeterlinck (RYKNER, 2004) na qual explora justamente a defecção do silêncio no classicismo francês.

Em As palavras e as coisas, Michel Foucault $(2016)^{18}$, no capítulo IV, intitulado Falar, reflete sobre a força e importância da palavra na Antiguidade Clássica, uma vez que o homem clássico acredita que a compreensão do mundo se dê por meio das coisas lidas; ao mesmo tempo, como essa palavra não representa o homem do Renascimento, mas dimensiona a complexidade da linguagem, ele concebe a palavra em seu estado bruto. A palavra é o próprio pensamento, não há nada além dela.

A esse respeito, destaco o que me parecera relevante:

Em relação a si mesma, a linguagem do século $X V I$ estava numa postura de perpétuo comentário: ora, este só pode exercer-se se houver linguagem - linguagem que preexista silenciosamente ao discurso pelo qual tenta fazê-la falar; para comentar, é preciso a antecedência absoluta do texto. [...] O enigma de uma palavra que uma segunda linguagem deve interpretar foi substituído pela discursividade essencial da representação: possibilidade aberta, ainda neutra e indiferente, mas que o discurso terá por tarefa concluir e fixar. (FOUCAULT, 2016, p.109)

17 La Mesnardière (1610-1663) foi poeta e dramaturgo francês. Escreveu La Poetique sob encomenda do Cardeal Richelieu. (CARLSON, 1997, p. 94)

${ }^{18}$ Também fui a ele por intermédio de Rykner (2004) 
É nesse contexto que a Pratique du Théâtre se torna tão importante. A palavra precisa apresentar-se de forma tal que debele a miríade representativa da linguagem. E esse controle da narrativa está totalmente a serviço do rei.

A obra de D'Aubignac é interessante não apenas para aqueles que desejem estudar a dramaturgia no classicismo francês, mas para qualquer um que pretenda iluminar-se sobre como a institucionalização do discurso pode se dar de maneira absolutamente clara e didática.

D’Aubignac abre seu volumoso estudo - o texto original tem 520 páginas -, no Livro 1 - capítulo 1, dizendo que a poesia dramática tem por finalidade a orientação moral dos homens cansados do trabalho ou da guerra e exalta $o$ espírito de "nossos governantes" (os dele, no caso) de proverem entretenimento ao povo, tal qual Roma e Grécia, cada qual dentro de seu espectro cultural, em que essa é uma arte "acessória" à dominação dos povos conquistados:

Les grecs les portèrent (les espectacles n.a.) dans l'Asie, et les romains dans l'Afrique, et dans l'Europe. Ils ne voulurent pas seulement donner leurs dieux et leurs loix aux peuples qu'ils avaient soûmis, ils y ajoûtèrent encore les jeux, et les spectacles, pour faire voir que leur domination n'était pas tyrannique, mais bien-faisante : qu'ils n'avaient pas pris les armes pour détruire les peuples, mais pour les rendre heureux ; et qu'ils eussent trouvé quelque chose à redire à leur felicité, s'ils ne l'eussent communiquée à toute la terre. Le theâtre de Sardis en I'Asie Mineure, celui de Cartage en Afrique, et ceux de Douay, de Nismes et d'Autun dans les Gaules, en sont des témoignages encore vivants ; bien qu'il ne nous en reste que de vieilles ruines. Et lors que le grand Constantin transporta le siège de l'empire dans cette ville celèbre, par les bâtiments qu'il y fit, et par son nom qu'il lui donna, il y voulut aussi transporter les jeux du cirque et du theâtre ; afin de monstrer qu'il n'y voulait pas seulement établir la puissance et la richesse, mais aussi tous les contentemens qu'un souverain pouvait donner à son peuple.. ${ }^{19}$ (AUBIGNAC F. H., 1657, p. 10)

${ }^{19}$ Os gregos os levaram (os espetáculos n.a.) para a Ásia, e os romanos para a África e para a Europa. Eles não apenas quiseram apresentar seus deuses e suas leis às pessoas que haviam dominado, mas também adicionaram jogos e espetáculos, para mostrar que sua dominação não era tirana, mas benevolente: eles não haviam utilizado armas para destruir os povos, mas para torná-los felizes, e tinham encontrado algo a dizer à sua felicidade, se não tivessem comunicado isso a toda a Terra. O teatro de Sardes, na Ásia Menor, o de Cartago, na África e os de Douay, Nismes e Autun na Gália, ainda são testemunhos vivos disso, embora deles só existam velhas ruínas. Quando o grande Constantino transportou a sede do império para esta cidade célebre, pelos edifícios que lá construiu e pelo seu nome, que a eles deu, ele também quis transportar os jogos do circo e do teatro, a fim de mostrar que ele não queria apenas estabelecer o poder e a riqueza, mas também todos os contentamentos que um soberano poderia dar ao seu povo. (tradução minha) 
No mesmo livro e capítulo, o autor agradece ao Cardeal de Richelieu pela oportunidade e confiança nele depositada para fazer esse estudo.

Meu desejo seria fazer uma análise detalhada desse estudo, porque ele encontra reminiscências em muitas das obras que lemos hoje acerca do discurso dramático, mas tenho que, herculeamente, manter-me no foco da pesquisa, que aparece no Livro 1 - capítulo 8:

\begin{abstract}
Mais dans le poëme dramatique, il faut que le poëte s'explique par la bouche des acteurs : il n'y peut employer d'autres moyens, et n'oserait par lui- même se meler avec eux pour achever l'explication des choses qu'il ne leur aurait pas fait dire ; si un temple ou un palais doit faire la decoration de son theâtre, il faut que quelqu'un des acteurs nous l'apprenne. S'il se fait un naufrage sur la scène, il y faut quelques acteurs pour l'expliquer, parlent du malheur de ceux qui périssent, et des éfforts de ceux qui se sauvent. ${ }^{20}$ (AUBIGNAC F. H., 1657, p. 34)
\end{abstract}

Aqui fica claro como D’Aubignac coloca a palavra acima de qualquer outro signo existente no teatro, acima até mesmo da visão do espectador. À guisa da reflexão de Foucault citada, a palavra deve orientar/fixar o que deve ser visto, não deixando margem à interpretação do que é representado.

Nesse contexto, se tudo que é visto deve ser expresso em palavras, o silêncio é impensável. Não há espaço para a prolixidade de um silêncio que não se possa controlar. De fato, Rykner (2004, p. 31). afirma "sem receio, que até o século XVIII o silêncio não é claramente reconhecido como componente da escrita dramática". No entanto, essa é o posicionamento estético oficial, mas há um número significativo de manifestações populares, no mesmo período, que não estão submetidas a tais cânones.

\title{
1.4.3 Um teatro do povo
}

Enquanto fervilhava a cena institucional na corte do Rei Louis XIV, paralelamente crescia o movimento de artistas de rua, com apresentações nas

\footnotetext{
${ }^{20}$ Mas no poema dramático, é necessário que o poeta se explique pela boca dos atores: ele não pode usar outros meios, e ele mesmo não ousaria nem mesmo se misturar com eles para completar a explicação das coisas que ele não Ihes teria feito dizer; se um templo ou um palácio deve ser a cenografia do seu teatro, é necessário que um dos atores nos ensinem. Se houver um naufrágio em cena, é necessário um dos atores para explicá-lo, falar da miséria daqueles que perecem e dos esforços daqueles que escapam. (tradução minha)
} 
feiras, que vinham de diferentes tradições e práticas como o circo, a pantomima, o ilusionismo, mas que, aos poucos, estabeleciam uma produção teatral. Os primeiros artistas de feiras aportaram em Paris no século XVI, como nos relata Camargo (2006, p. 17):

(...) mas em 1680, Luís XIV lança o edital que funda a Comédie Française que será investida da exclusividade de encenar peças teatrais em Paris, e os demais atores serão proibidos de se estabelecer na cidade, a menos que fossem expressamente autorizados por Sua Majestade.

Há uma rica narrativa sobre esse movimento em uma obra intitulada Les spectacles forains et la Comédie française : le droit des pauvres avant et après 1789, les auteurs dramatiques et la Comédie Française au dix-neuvième siècle ${ }^{21}$, escrita por Jules Bonnassies (1875). Ele recupera a relação tempestuosa entre os autores oficiais e companhias de teatro que ocupavam a Comédie Française nos dois séculos anteriores à Revolução. Esse recorte é muito significativo, uma vez que mostra exatamente o embate entre a arte produzida oficialmente pelos "autores do rei" e o teatro popular que ocorria nas feiras. É uma briga de poder que conota claramente a ascensão da burguesia na França e que começa a despontar também nos procedimentos estéticos. E o mais fascinante dentro do escopo dessa pesquisa é que havia um ingrediente no centro do debate: a palavra. Em determinado momento, a luta será por quem tem direito à palavra na cena francesa.

A cena parisiense do XVII se organizava entre alguns espaços de representação: o Hôtel de Bourgogne, onde se apresentavam as tragédias clássicas, e o Théâtre du Marais, onde aconteciam as comédias; além disso, havia seis grandes feiras em Paris, mas duas eram locais de representação: as feiras de Saint-Germain, que duravam de 3 de fevereiro à Pascoa, e as de Saint-Laurent no verão europeu. (CAMARGO, 2006)

A questão era que os comediantes franceses, como eram chamados os artistas que ocupavam a cena oficial, ficavam extremamente incomodados com os artistas das feiras por dois motivos principais: a proximidade das localidades

\footnotetext{
${ }^{21}$ Os espetáculos das feiras e a Comédia Francesa: o direito dos pobres antes e depois de 1789, os autores dramáticos e a Comédia Francesa no século XIX. (tradução minha)
} 
oficiais de representação e a popularidade da qual gozavam algumas companhias.

Bonassies (1875) mostra as ocorrências policiais e as tentativas de expulsão impetradas pelos comediantes franceses. No entanto, estamos falando de uma gente acostumada à luta pela sobrevivência, fazendo sua arte em meio às batatas, como diz Robson Corrêa de Camargo (2006, p. 13-14):

É importante detalhar que os espetáculos da feira, empreendimentos
privados e não permanentes, não eram subvencionados pelo rei nem
por seu entourage, e, ao lado das batatas, dependiam apenas de sua
venda nas bilheterias. O sucesso era o primeiro objetivo de seus
espetáculos que não se propunham apenas a sensibilizar o público,
mas a conseguir que este desse moedas em troca dessa sensibilização.

O choque entre os artistas de feira e os comediantes franceses representava o entrave entre a sobrevivência e a manutenção dos privilégios.

Tudo acontece porque a Comédie começa a perder público para os feirantes e lança mão de seus privilégios para impedir o avanço desses últimos. Molière, inclusive, contrata Michel Baron, órfão de pai e oriundo de uma família de artistas de feira, para trabalhar em sua companhia, tamanho o talento do menino, mas este foge devido aos maus tratos de seu novo patrão.

Como relata Bonassies (1875), os primeiros momentos do embate mais direto acontecem em correspondências administrativas entre Louis XIV e La Reynie, o censor, proibindo a apresentação de fantoches de Brioché. La Reynie, que já tinha autorizado, escreve uma carta, em outubro de 1676, dizendo que posteriormente determinará o local onde poderão ser feitas as apresentações. Em maio de 1677, em outra carta, o rei proíbe as apresentações com música, dizendo que contrariam o privilégio de Lulli ${ }^{22}$. Em 1679, Louis XIV permite que o acrobata Richardson dê seus saltos, acompanhados por alguns discursos, desde que ninguém cante ou dance. Os que desobedeciam a essas ordens tinham seus equipamentos destruídos, pagavam multas e/ou eram presos.

Os feirantes conseguem se organizar e alugar os teatros oficiais por temporadas, a fim de fazerem suas representações. Se não podiam se apresentar na rua, agora migravam para o teatro. As temporadas eram muito mais longas do

\footnotetext{
22 Jean Baptiste Lully (1632-1687), parceiro de Molière, e um dos criadores da comédie-ballet, gênero teatral na qual a dança está intimamente ligada à palavra. (BERTHOLT, 2014)
} 
que se supunha a princípio, porque o público era muito mais afeito às comédias populares do que à fala aristocrática dos comediantes.

Em 1698, os comediantes exigem a retirada dos "forains" (forasteiros) do teatro e a demolição da estrutura das feiras. Isso provoca uma revolução ímpar, porque os feirantes aproveitaram a estrutura dramatúrgica herdada dos comediantes dell'arte italianos, adaptaram o que envolvia as apresentações circenses e de marionetes e dedicaram-se à construção de um teatro popular genuíno. (BONASSIES, 1875)

No início dos anos 1700, essas representações eram muito populares e os comediantes impediram que houvessem diálogos na cena.

Chegamos à conclusão da progressão de eventos desse embate, mas é preciso parar no exato ponto, que é exatamente para onde essa pesquisa converge: Racine fazia parte do entourage de Louis XIV, portanto era um dos comediantes que se embrenharam nesse embate para impedir a realização de um teatro popular. É nesse momento da história que os comediantes a serviço do rei, movidos pela manutenção de seus privilégios, retiram a voz dos feirantes, mas isso não os cala. Os feirantes utilizam-se então do recurso da mímica, representando em silêncio.

Essa cena muda segue uma dramaturgia específica, observada por Camargo (2006, p. 26):

A dramaturgia do texto procurava apenas ser descritiva, um roteiro descritivo de ações, muito diferente dos textos registrados pelos autores clássicos, mas aqui ela era construída pelo ator e por sua companhia para desenvolver a personagem. Fazia parte da tradição oral que cativava a plateia de seu tempo. Mais afeito ao espetáculo que ao diálogo, o texto preocupava-se com as rubricas ou didascálias, pois este diálogo, proibido ou evitado, estava implícito ou explicitamente desenvolvendo-se em um dinâmico jogo teatral com a plateia.

Como não era teorizada, nem houvesse poéticas que a constituíssem, essa dramaturgia partia da relação de experiência dos atores com o público, sem cânones, nem normas rígidas ${ }^{23}$.

23 Existe um imbróglio dramatúrgico em relação ao teatro das feiras. Acontece mais especificamente na Itália do século XVIII. Renata Pallottini (1989) aborda o tema em um capítulo intitulado $A$ Polêmica das situações dramáticas. Nesse período havia uma oposição entre Gozzi e Goldoni, ambos dramaturgos italianos. Goldoni promoveu uma reforma na Commedia Dell'Arte redigindo integralmente os textos a serem encenados, enquanto Gozzi lutava pela manutenção 
Com o tempo, as proibições foram cedendo, e as barracas foram se modificando, até que surgisse um espaço permanente para o teatro popular, o Le Boulevard du Temple.

da tradição dos espetáculos de feira preservando as máscaras e o sistema de canovacci, que consistia em um roteiro de situações para que o "texto" nascesse por meio da improvisação. Nesse sentido pode-se pensar que uma parte da feira absorveu, ao longo dos séculos, alguns paradigmas da cena oficial. 


\section{O SUJEITO DA FALA}

Nosso papel não é falar ao povo sobre a nossa visão do mundo, ou tentar impô-la a ele, mas dialogar com ele sobre a sua e a nossa. Temos de estar convencidos de que a sua visão do mundo, que se manifesta nas várias formas da sua ação, reflete a sua situação no mundo, em que se constitui. (FREIRE, 2015, p. 120)

As poéticas escritas ao longo da história trazem uma ideia normativa para a construção de uma dramaturgia ideal. Para que ela exista, no entanto, há a necessidade do sujeito, de alguém que a concretize, que se debruce a escrever palavras no papel ou algo que equivalha. Esse responsável por juntar, combinar, arranjar ideias de forma a compor a dramaturgia sofreu, ao longo da História, perpassado pelo tempo e espaço, inúmeras transformações. Quero, agora, fazer uma breve reflexão sobre alguns movimentos desse processo.

No primeiro capítulo, apresentei algumas poéticas inseridas em seus contextos históricos. O condutor foi a enunciação de Aristóteles. oriunda da sua observação crítica acerca da tragédia ática, sua contemporânea, e da Pratique du Théâtre, escrita por D'Aubignac, influenciada tanto por Aristóteles como pela necessidade de manutenção do status quo na França ${ }^{24}$.

Como já disse, o traslado da História acontece no tempo e no espaço, mas, para a facilidade de construção de uma linha lógica, permanecerei seguindo o fio do que aconteceu na França. Aproximadamente um século após os escritos de D'Aubignac, em 1758, outro pensador francês desenha uma poética do teatro, só que agora com vistas à cena. Denis Diderot, em seu Discurso sobre a Poesia Dramática (2005), coloca a verdade como aspecto essencial na criação de uma

\footnotetext{
${ }^{24}$ Porém é importante esclarecer que esse é um recorte. Apenas como exemplo de que esse panorama é bem mais amplo do que apresentei, é importante lembrar que, ao mesmo tempo em que Racine escrevia seus dramas e tragédias, obediente aos cânones do classicismo francês, que, por sua vez, bebeu em Aristóteles - "dos três dramaturgos do século, ele é o mais fiel à tradição neoclássica" (CARLSON, 1997, p. 100), - o teatro de Shakespeare, na Inglaterra, e o de Calderon, na Espanha, já tinham se estabelecido com elementos de autoria particulares e que não coadunavam, em muitos aspectos, com os franceses. A respeito disso, diz Szondi: “... a dramaturgia da época elisabetana já havia rompido algumas vezes a cláusula dos estados, ao passo que, no decorrer do século XVIII, a tragédie classique francesa continuava a ser tratada como norma inviolável. (2014, p. 85). A cláusula dos estados é apresentada um pouco adiante nesta dissertação.
} 
relação dialógica com o espectador. Sua cena, como um dos importantes pensadores do período que antecede a Revolução Francesa, alimenta-se das ruas, observando a excitação popular, acompanhando o teatro de feira, visando não apenas ao gestual dos atores, mas à representação do cotidiano, esse teatro anônimo que acontece fora dos palcos e dentro das relações sociais. Ele reflete o humano, dentro da sua realidade, e não a imagem do humano ideal:

Suponhamos, portanto, que dois homens, em dúvida se devem estar descontentes ou satisfeitos um com o outro, estejam esperando um terceiro que os informe: o que dirão até que este terceiro chegue? Nada. Irão e virão, se mostrarão impacientes, mas ficarão calados. (DIDEROT, 2005, p. 116)

Ao fazer essa reflexão, dando vistas à realidade, Diderot reconhece a complexidade da cena e os seus signos, observando não apenas as palavras no papel, mas a construção da ação como um todo.

Façamos um breve exercício de imaginação. A cena oficial, segundo a Comédie, era composta de uma série de signos artificiais, habilmente construídos, tencionando a manutenção de poder. Não apenas o gestual como a figura humana era completamente postiça, e portava altas perucas e saltos ${ }^{25}$. $\mathrm{O}$ próprio Louis XIV representou o Rei Sol ${ }^{26}$. O texto era alexandrino ${ }^{27}$, se apresentava muito diferente da prática de fala cotidiana. Por outro lado, Diderot ocupava-se da naturalidade das coisas. Em Paradoxo sobre o comediante, escrito por meio do diálogo entre dois interlocutores, Primeiro e Segundo, o autor revela sua a crítica à poesia dramática de seu tempo:

O Segundo

Nosso verso alexandrino é harmonioso demais e demasiado nobre para o diálogo.

O Primeiro

E nosso decassílabo é demasiado fútil e demasiado leve... Como acho pomposos nossos autores dramáticos! ( (DIDEROT, 2006, p. 67)

25 "Um grande cortesão, acostumado, desde que respira, ao papel de fantoche maravilhoso, assume toda espécie de formas, ao bel-prazer do barbante que está nas mãos do seu senhor." (DIDEROT, 2006, p. 56)

${ }^{26}$ Em 1653, Louis XIV participou de uma peça-dança intitulada Ballet de La Nuit. (BERTHOLD, 2014, p. 334)

${ }^{27}$ Verso com doze sílabas poéticas. 
Acrescente-se a tudo isso que havia o teatro popular, acessível a todos, nas ruas, e não restrito a salas fechadas, para os poucos que pudessem pagar; era aquele teatro em meio a legumes e hortaliças, que tinha sido oficialmente condenado ao silêncio, o que acabou por promover uma grande reforma estética das ruas.

O teatro de feira usou de muitos ardis para que os artistas mantivessem o seu ganha-pão: o primeiro recurso foi a pantomima ${ }^{28}$, observada por Diderot (2005, p. 116) como "uma parcela do drama a que o autor deve dedicar-se seriamente". O primeiro movimento pela sobrevivência desse teatro foi retirar a palavra e substituí-la por gestos significativos que, muitas vezes, aludiam às figuras públicas responsáveis pelos atos de censura cometidos: um levantar de sobrancelhas, por exemplo, um rapapé exagerado, gestos já característicos o suficiente para que o espectador identificasse o sujeito da representação. Mas esse estilo não duraria muito, e logo algumas palavras do texto seriam introduzidas à cena:

... os comediantes praticavam a diferença entre escrita e fala e desenrolavam o texto de seus bolsos, mostrando-o à plateia, contendo o indispensável ou indicando apenas o sentido da passagem de uma cena a outra. Os atores podiam recitar, mas desde que fossem palavras sem sentido e que conviriam ao sentido da gestualidade. Entretanto, no teatro tudo significa e, muitas vezes, estes grunhidos lembravam explicitamente a melodia dos versos alexandrinos de várias peças que estavam sendo apresentadas pelos atores reais. (DIDEROT, 2006, p. 22)

Às vezes, esses cartazes mostravam letras de canções. E, como estava proibida a execução de música no teatro feito pelos feirantes, os espectadores cantavam, enquanto os atores representavam silenciosos, acompanhados por uma trilha sonora feita pela plateia.

É desses acontecimentos que o pensamento de Diderot e a sua produção estão embebidos, ou seja, às margens de uma revolução que mudou a história das relações sociais. Além disso, ele também propõe uma mudança na função

${ }^{28}$ Pantomina "(do grego pantomimos, que imita tudo)". A antiga pantomima estava ligada à representação de tudo, tanto pela voz como pelo gesto. Em Roma, a pantomima separa o texto do gesto; nesse caso, o ator mima os comentários do coro e dos músicos. A pantomina tem seu auge nos séculos XVIII e XIX no teatro não verbal. A pantomima à qual Diderot se refere é a "sem palavras", usada pelos atores das feiras. (PAVIS, 2015, p. 274) 
política do dramaturgo, que passa de um arquiteto de diálogos a observador do mundo. Ele é um dos autores que operam uma transformação nos cânones trágicos, gradualmente convergindo para um gênero intitulado Tragédia Doméstica, que tem a cena calcada no cotidiano burguês, até desembocar no Drama, que se torna a voz cênica desse momento histórico.

\subsection{O Drama burguês}

O legado de Aristóteles, seus críticos e tradutores promoveu uma série de entendimentos quanto à excelência do gênero dramático, alguns bastante dogmáticos, conforme já foi dito.

Apesar de não se encontrar em textos de Aristóteles, sua "leitura" instaurou a crença segundo a qual o herói trágico tinha que ser um rei ou príncipe, e a isso se deu o nome de cláusula dos estados.

Em seu livro Teoria do drama burguês: século XVIII, o professor Peter Szondi propõe, por meio de uma análise comparativa entre a poética e a dramaturgia de alguns poetas dramáticos, promover uma reflexão acerca do que vem a ser caracterizado como drama burguês que, em um primeiro momento, nasce justamente de um movimento antitético em relação a essa tal cláusula. Lukács, a partir de Szondi, elucida o tema:

O drama burguês é o primeiro a se desenvolver a partir de uma
oposição consciente de classes; o primeiro cujo objetivo era dar
expressão ao modo de sentir e pensar de uma classe lutando por
liberdade e poder e à relação que mantinha com as demais classes. Daí
se segue logo que geralmente duas classes devem cerrar fileiras no
drama, a que luta e aquela contra qual se combate. (LUKÁCS, Georg ${ }^{29}$,
1914 apud SZONDI, 2014, p. 23)

Aristóteles, ou a leitura que se fez dele, ainda era a base. A questão apresentada pelo drama burguês não estava relacionada ao contingente, mas ao seu conteúdo. Para Szondi, a cláusula dos estados pode ter surgido com um comentador de Aristóteles, Dacier, no classicismo francês (1692):

Traduz a frase do capítulo 5, que corresponde ao começo da definição, com "une imitation des actions de plus grands personnages" e observa

\footnotetext{
${ }^{29}$ LUKÁCS, George. Zur Soziologie des modernen Dramas in Archiv für Sozialwissens-chaft und Sozialpolitik. Parcialmente reimpresso in Peter Ludz (ed.), Schrifien zur Literatur-soziologie. Neuwied, 1961, p.277.
} 
a propósito disso: “C'est ainsi qu'il faut traduire ce passage [...]. Et non pas 'une imitation des actions ilustres et importantes'" (DACIER ${ }^{30}$, André, p.65 apud SZONDI, 2014, p. 40) ${ }^{31}$

Mas Diderot vai um pouco mais longe em relação à clausula dos estados, não apenas no que diz respeito ao protagonismo dos reis na tragédia, como também observando que dentro da busca pela verdade, em diversas situações, alguns sentimentos - como horror, desespero, tristeza - retiram de reis e rainhas seus papeis sociais, fazendo com que percam sua "realeza".

Apresento agora um trecho dentro do universo de Phèdre, meu objeto de pesquisa, que é significativo com relação a essa proposição de Diderot. Neste trecho $(\mathrm{V}, 7)$, Phèdre se apresenta agonizante à Thésée, após ter tomado veneno e estar preparada a contar tanto a verdade de seu amor proibido como a mentira responsável pela fúria do rei, e consequente morte de seu filho, Hippolyte:

\author{
Ato $\mathrm{V}$, cena 7 \\ Phèdre \\ Non, Thésée, il faut rompre un injuste silence; \\ II faut à votre fils rendre son innocence. \\ II n'était point coupable. \\ Thésée \\ Ah! Père infortune! \\ Et c'est sur votre foi que je l'ai condamné! \\ Cruelle, pensez-vous être assez excusée... \\ Phèdre \\ Les moments me sont chers, écoutez-moi, Thésée. \\ C'est moi que sur ce fils chaste et respectueux \\ Osai jeter um oeil profane, incestueux. \\ Le ciel mit dans mon sein une flamme funeste; \\ La détestable Oenone a conduit tout le rest. [...] (RACINE, 2000, pp. 120-121) ${ }^{32}$
}

${ }^{30}$ DACIER, André, La Poétique d'Aristotele, trad.francesa, com notas. Paris, 1692.

31 "Uma imitação das ações de personagens maiores" "Essa é a maneira de traduzir essa passagem [...]. E não 'uma imitação de ações ilustres e importantes' ". (tradução minha)

${ }^{32} \mathrm{Não}$, Teseu, devo enfim romper a reticência,

A Hipólito é mister restituir a inocência:

Não foi culpado, não.

Thésée

Oh, pai desventurado!

E é sobre a vossa fé que o venho condenado!

Cruel! Podeis pensar que algum indulto meu...

Phèdre

Cada instante é precioso; ouvi-me, pois Teseu:

Fui eu que ousei poluir esse filho exemplar, 
Pensando de uma maneira diderotiana, não é crível que uma mulher em agonia consiga rimar em versos alexandrinos e escolher palavras com tamanha desenvoltura. Fedra teria que aparecer descabelada, balbuciante, proferindo pequenas sentenças mal desenhadas. Mas na tragédia clássica, Phèdre é Phèdre até na morte. Em $O$ filho natural, Diderot profere, por seu alter ego, Dorval: "Je me suis demandé quelques fois si la tragédie domestique se pouvait écrire em vers; et, sans trop savoir pourquoi, je me suis répondu que non". ${ }^{33}$ (SZONDI, 2014, p. 99)

Phèdre é um texto originalmente escrito sem didascálias, no entanto, na edição de Raymond Picard (2000, p. 120), há um apontamento de intenção da personagem, tamanha a necessidade do editor de garantir a compreensão de que Phèdre não está nada bem nesse momento, apesar da indefecção de duas palavras (eu suponho):

Phèdre s'avance alors. C'est une Phèdre lucide, déjà sortie de l'action tragique, morte à ele-même et à ses égarementes, avant de mourir au monde. Elle fait le récit de son esclavage résume l'action, nous donne toutes les "clefs" de la tragédie: la necessité tragique, l'impitoyable enchaînement des actions rendues vaines, tout cela est découvert dans ce regard inutilement perspicace que Phèdre jette après coup sur I'histoire de son malheur achevé. ${ }^{34}$

Diderot nos apresenta a ideia de que o quadro (tableau) é uma noção que carrega a potência da verdade (veritê) no lugar da representação da realidade. Esse binômio tableau-verité é essencial na poética do autor. Szondi apresenta um trecho do diálogo da obra $O$ filho Natural, de Diderot, no qual essa noção fica bem clara:

Vi ali um quadro e ouvi ali um discurso que jamais esqueci. O morto estava estendido sobre um leito. Suas pernas nuas pendiam para fora. Sua mulher desgrenhada estava no chão. Segurava os pés do seu marido; e dizia afundando em lágrimas, e com movimentos que a livravam de todo o mundo: "Ai! Quando te enviei para cá, não pensei

Tão casto quão leal, com incestuoso olhar.

O céu me pôs no peito um fogo tão funesto;

Conduziu a execranda Oenone todo o resto. [...] tradução Jenny Klabin Segall (2005, pp. 81-82)

${ }^{33}$ Eu já me tinha perguntado algumas vezes se a tragédia doméstica se poderia escrever em verso; e, sem saber muito porquê, havia-me respondido que não.

${ }^{34}$ Fedra então avança. É uma Fedra lúcida, já fora da ação trágica, morta para si e para seu delírio, antes de morrer para o mundo. Ela narra sua escravidão, resume a ação, nos dá todas as "chaves" da tragédia: a necessidade trágica, o impiedoso encadeamento de ações em vão, tudo isso é descoberto neste olhar inesgotável que Fedra lança depois do fato, sobre a história de sua desgraça acabada. (tradução minha) 
que estes pés te levariam à morte". Credes que uma mulher de outra posição teria sido mais patética? Não. A mesma situação lhe teria inspirado o mesmo discurso. Sua alma teria sido aquela do momento; e o que o artista precisa encontrar é o que o todo mundo diria em caso similar. (DIDEROT, D. ${ }^{35}$ apud SZONDI, 2004 p. 94)

A verité está relacionada com a exibição conveniente da natureza das coisas, criando um encadeamento tal que se relacione com o real. Com essa ideia, Diderot propõe o diálogo em prosa com uso do recurso narrativo, a presença da cena doméstica e a valorização do silêncio e da pantomima. Com essas proposições, acaba por configurar uma opção política que se opõe não apenas à estética vigente, mas também ao poder naquele momento instituído, à monarquia absolutista:

A pequena família burguesa que - em oposição à grande família feudal
- introduz pela primeira vez uma separação do privado e do público,
que tem sua essência no isolamento de um espaço privado em relação
à esfera pública, ou seja, também em relação ao estado e à política, é
para Diderot, na medida de suas possibilidades, uma garantia de
felicidade [...] embora a práxis dramática se limite a reproduzir as
relações dos membros da família entre si, Diderot faz da tragédie
domestique et bourgeoise a exposição e a defesa da pequena família
burguesa e sentimental como utopia real. (SZONDI, 2014, p. 132)

À guisa de elucidação, uma vez que exponho, neste capítulo, a persona que escreve o drama, é importante salientar também suas contradições. Construí um quadro e propus a localização do intelectual revolucionário Diderot, observador do teatro oriundo das ruas da França e das manifestações populares, forjando um teatro que estava aquecido pela Revolução. No entanto, a ação diderotiana acontece dentro de casa, na instância privada, essa é sua utopia, como afirmou Szondi acima citado. E é exatamente nesse aspecto que acontece a contradição entre a poética e a política.

Diderot revolve a cena francesa, é um dos grandes intelectuais da Revolução, redator da histórica Enciclopédia, "romancista genial, crítico de arte, dramaturgo e crítico de teatro." (DIDEROT, 2005, p. 15) Um homem ocupado com a verdade, mas, sobretudo comprometido com a classe burguesa que se projeta na sociedade e, o que é mais instigante, com as emoções individuais de alcance privado. Com Diderot, a tragédia dos palácios cede lugar às lágrimas da

${ }^{35}$ DIDEROT, Denis. Entretiens sur 'Le fils naturel. In Ouvres esthétiques, Paris.1757. 
sala de estar. Em O filho natural, por exemplo, o tema é o amor impossível, devido a implicações sociais, entre dois jovens, Dorval e Rosali, revelado ao público por meio de um ousado meta-teatro. A discussão, no entanto, não se limita a isso, é também sobre os modelos de dramaturgia, conforme comentário do Professor Dr. Franklin de Mattos (1996, p. 96):

\begin{abstract}
As Conversas confrontam esse ${ }^{36}$ "uso do teatro" às várias transgressões da peça $O$ filho natural: Constança confessa a Dorval sua paixão por ele, o que não "convém" a uma mulher segundo o teatro; o criado Charles conversa familiarmente com seu senhor, o que não "convém" às condições de um e outro; Dorval se põe a tomar chá em cena, o que não "convém" aos hábitos de um francês. Não são estas "minúcias", entretanto, o que mais importa. A conversa entre Dorval e seu interlocutor não se demora em usar alguns exemplos que contestam a regra do decoro no seu princípio mais geral.
\end{abstract}

O teatro do quadro (tableau) em si guarda uma modernidade que, por uma sucessão de acontecimentos no tempo e espaço, causais e casuais, simultâneos e díspares, aponta para o que viria a ser o teatro épico.

No longo verbete sobre o trágico, Pavis propõe o tópico Desativação do Trágico, com qual abre dizendo: "a própria possibilidade do trágico está vinculada à ordem social". A ideia é de que o herói aceita se submeter aos sólidos valores a ele impingidos, a fim de que a ordem se reestabeleça. "A ordem é sempre estabelecida no fim do caminho, seja ela divina, metafísica ou humana." (PAVIS, 2015, p. 419). No final do mesmo verbete, vaticina "Chamaremos de 'tragédia' toda peça pela qual os conflitos são necessariamente insolúveis, e 'drama' toda peça na qual os conflitos são resolvidos."

O século XVIII na França, com a ascensão de uma classe que prima por empreender e subverter a ordem social - a burguesia -, promove uma forma dramatúrgica que não cede ao inexorável, porque não há nada que possa transpor o humano e sua capacidade de trabalho. O conflito de classes motiva mais do que pequenas mudanças no conteúdo da dramaturgia, mas uma revolução estética cujo protagonismo deixa de ser dos deuses e passa a ser do homem.

\footnotetext{
${ }^{36} \mathrm{De}$ acordo com o respeito ao decoro e à moral, o ator não deve chocar o espectador. Como resultado, a violência e a intimidade física são excluídas da cena. Batalhas e mortes devem acontecer fora do palco e serem relatadas ao público como narrativas. (BERTHOLD, 2014)
} 


\subsection{O épico}

Esse é o momento do espanto. Se me propus a estudar o dramático, se minha orientação dramatúrgica parte de Aristóteles, que impetra "não transformar uma tragédia numa estrutura épica" (ARISTÓTELES, 2008, p. 76), por que torna-se necessário um subcapítulo que referencie o épico?

Eu e todos os criadores cênicos que participaram desta pesquisa são pessoas oriundas do século XX e que desembocaram no XXI. Nossas influências estéticas são um amálgama de todas as estruturas que vimos, lemos, vivemos, encenamos. Nosso campo de pesquisa firma-se na tragédia clássica Phèdre, mas como se trata de uma reescritura, uma percepção criativa da obra, nossa vista necessariamente está tomada pelos eventos que se colocaram entre nós e Racine.

Um dos eventos importantes desse trajeto, que também passa por Diderot, é a crise da forma dramática e da normativa à qual se submete. Szondi (2001) aborda a crise do drama em função de um paradoxo existente na cena cujas personagens têm que, necessariamente, dialogar para existir: "O homem só entrava no drama como ser que existe com outros". Ele esclarece:

A supremacia absoluta do diálogo, ou seja, daquilo que se pronuncia no drama entre homens, espelha o fato de este se constituir exclusivamente com base na reprodução da relação inter-humana e só conhecer o que nessa esfera reluz. (2001, pp. 23-24)

É justamente esse aprisionamento na existência deliberadamente dialógica que, gradativamente, impele dramaturgos e dramaturgas a buscarem outros meios de expressão. E, ao longo do século XIX, visualizam-se movimentos de "epicização" do teatro, ou seja, o dramaturgo ou a dramaturga "vazam do papel" e "escapam pela boca" da personagem. A personagem não ignora mais a plateia, antes dialoga com ela. Acontece a quebra da idealização de atores e atrizes em um palco, agindo como bibelôs a serem apreciados como entretenimento do espectador, e começam as reflexões sobre as questões do indivíduo para, em seguida, recaírem no entorno.

Quando inicia o século XX, carregado de mudanças tecnológicas, meios de produção e relações sociais, o teatro tende a tornar-se importante campo de 
reflexão. A dramaturgia passa a ter novas demandas. Conforme Margot Berthold (2014, p. 451), Taine ${ }^{37}$ declarava que seu dever "era levar ao palco uma realidade que explicasse todo o comportamento humano conforme determinado pela 'raça, meio ambiente e momento"'. A forma dramática, nesse contexto, precisava de alternativas. Segundo Szondi (2001), a primeira corrente dramática importante e à qual toda uma geração aderiu foi o expressionismo, que tem como premissa a impossibilidade da mimese, uma vez que "por mais real que possa ser o indivíduo em sua relação com os outros, considerado como algo absoluto, ele é uma mera abstração" (2001, p. 106). Disso decorre uma deformação subjetiva do indivíduo, mas ao contrário do que se possa supor, ela se dá na relação com o seu ambiente. Como se o ambiente - e aqui diz não do espaço físico, mas do ambiente constituído pelas relações sociais -, o contrastasse. Cito o trecho de Edschmid referido por Szondi (2001) que considero bastante elucidador, um dos mais importantes escritos teóricos sobre o expressioninsmo:

O homem [singular] não é mais o indivíduo, atado ao dever, moral, sociedade, família. Nessa arte ele não se torna senão o que há de mais sublime e mais lamentável: ele se torna homem. Eis o novo e inaudito frente às épocas anteriores. Aqui não se pensa mais nos moldes da burguesia do mundo. Aqui não há mais vínculos a ocultar a imagem do humano. Não há mais histórias conjugais, tragédias que nascem do embate entre convenção e carência de liberdade, peças de milieu ${ }^{38}$, diretores rigorosos, oficiais bons vivants, nem títeres suspensos por fios de concepções psicológicas que com leis, pontos de vista, erros e vícios dessa existência social feita e construída por homens, jogam, riem e sofrem. (EDSCHMID ${ }^{39}$, Kasimir p.57 apud SZONDI, 2001, p. 108)

Nesse momento, além de observar o mundo, como havia posto Diderot, a dramaturgia tem a função de revelá-lo em sua intimidade. Os dramaturgos e dramaturgas desvinculam-se cada vez mais da formalidade do drama,

\footnotetext{
${ }^{37}$ Hippolyte Adolphe Taine (1828-1893), intelectual e historiador francês. (JÚNIOR, 2011, p. 2)

${ }^{38}$ As peças de milieu (meio) foram concebidas pelo dramaturgo, diretor, cineasta e crítico francês André Antoine (1858-1943) e têm como premissa o teatro da realidade que consistia na reprodução exata da vida, mostrando aposentos com portas que abriam e fechavam, janelas, cômodas com roupas e outros pertences. Nesse sentido, a representação era dada na relação com o "meio" de que era constituída a cena. (2014, pp. 453-454)

${ }^{39}$ EDSCHIMID, K. Über den expressionismos in der literatura und die neue dichtung [Sobre o expressionismo na literatura e a nova poesia], Berlin, E.Reiss, 1919.
} 
constituindo proposições estéticas não estáticas. Nessa esteira, surge a necessidade de provocar a reflexão e, a partir da inspiração no drama social e do surgimento do cinema ${ }^{40}$, surge o teatro épico.

Anatol Rosenfeld (1985), resgatando Sócrates, expõe de forma bastante didática o que vem a ser o épico, conceito que, com ajustes mínimos, permanece até hoje:

Sócrates explica que há três tipos de obras poéticas: "O primeiro é inteiramente imitação." o poeta como que desaparece, deixando falar, em vez dele, as personagens. "Isso ocorre na tragédia e na comédia." o segundo tipo "é um simples relato do poeta; isso encontramos principalmente nos ditirambos." [...] "O terceiro tipo, enfim, tem ambas as coisas; tu o encontras nas epopeias ... " Nesse tipo de poemas manifestase o próprio poeta (nas descrições e na apresentação dos personagens), ou outro personagem (quando o poeta procura suscitar a impressão de que não é ele quem fala e sim o próprio personagem, isto é, nos diálogos que interrompem a narrativa). (ROSENFELD, 1985, p. 15, grifo meu)

Rosenfeld continua suas considerações sobre o épico, afirmando que é um gênero que expõe a voz do autor por narração, em um diálogo direto com o espectador. Por comparação, no lírico é possível que, em monólogo, alguém fale consigo mesmo e reflita sobre a sua condição. Esse ser pode demonstrar que não dirige a palavra exatamente a alguém, mas, quando se narra, há a necessária inclusão do interlocutor. (ROSENFELD, 1985, p. 24-26) O épico faz a exposição do teatro, da representação.

Também em Racine, devido à rigidez das poéticas do classicismo francês que se apresentavam como manuais (e aqui sublinho a de D'Aubignac), o fato de colocar a descrição do acontecimento cênico na boca da personagem acaba por criar uma circunstância com dimensões épicas; exemplo disso é quando, também em função do decoro que impedia a exibição das cenas rudes e do pathos, Théramène narra a sequência de morte de Hippolyte:

\footnotetext{
${ }^{40}$ Margot Bertholt (2001) apresenta o drama social proposto por Piscator promove uma revolução na encenação que, em seguida, terá ressonância na dramaturgia. Piscator propõe que a função social do teatro é refletir as relações sociais: "Sempre que ele entra em cena, também entra com ele sua classe ou camada social" (2001, p. 111). Com ele a cena incorpora a tecnologia e multifaceta o palco com praticáveis, projetos de fotografias e cenas de cinema. No âmbito da dramaturgia propriamente dita, sua maior invenção tinha um objetivo didático: o narradorcomentador.
} 


\begin{abstract}
Ato $\mathrm{V}$, cena 6
THÉRAMÈNE

À peune nous soraient tions des portes de Trézène,

Il était sur son char. Ses gardes affligés

Imi son silence, autour de lui rangés;

II suivait tout pensif le chemin de Mycènes;

Sa main sur ses chevaux laissait flotter les rênes.

Ses superbes cousiers, qu'on voyait autrefois

Pleins d'une ardeur si noble obéir à as voix,

L'oeil morne maintenant et la tête baissée,

Semblaient se conformer à sa triste pensée.

Un effroyable cri, sorti du fond des flots,
\end{abstract}

Des airs en ce moment a troublé les repôs. (RACINE, 2000, p. 115) $)^{41}$

Nesse pequeno trecho da minuciosa descrição de Théraméne, observase que a resolução de Racine para mostrar ao espectador a agonia de Hippolyte é uma "epicização" do drama. Esse recurso promove também uma mudança de qualidade na atenção do espectador que, no lugar de observador de fatos dados pela constante presença dialógica das personagens, passa a co-criar a cena narrada, uma vez que a representação se encontra na sua subjetividade.

\title{
2.2. 1 O Pequeno Organon para o teatro
}

Em 1948, uma pequena obra feita de aforismos numerados propõe uma nova revolução no teatro: trata-se do Pequeno Organon para o Teatro, de Bertolt Brecht (1967, p. 181-219), no qual ele estabelece a ruptura com a dramaturgia aristotélica. Estamos novamente diante de uma poética e, assim como Aristóteles, D’Aubignac e Diderot, Brecht serve-se do que, segundo ele, é "uma época científica". Sua reflexão sobre essa ciência é de que ela aponta para a

\footnotetext{
${ }^{41}$ Das portas de Trezena havíamos saído, Sobre o carro ele estava; em formação de escolta, A guarda aflita e muda andava a sua volta Seguia pensativo a rota de Micenas No dorso dos corcéis flutuava a brida, apenas; Soberbos animais, que a gente outrora via Seguir com flâmeo ardor a voz do ilustre guia, Tristes, ora, inclinada a fronte a passos lentos, lam, como a espelhar-Ihe os tristes pensamentos. Um grito pavoroso, emerso do imo mar, Abalou, nesse instante, a paz serena do ar [...] tradução Jenny Klabin Segall (RACINE, 2005, p. 77)
} 
submissão da espécie humana, em uma relação na qual a classe burguesa, que domina os meios, subjuga quem não os detém:

\begin{abstract}
17
Embora as novas ciências tenham possibilitado uma mudança extraordinária e, acima de tudo, tenham conferido ao nosso mundo uma grande plasticidade, não se pode dizer que seu espírito nos preencha e determine a todos. A razão pela qual o novo modo de pensar e sentir ainda não penetrou profundamente nas grandes massas humanas deve ser buscada no fato de que as ciências, apesar de seus sucessos na exploração e dominação da natureza, são dificultadas pela classe burguesa (cujo poder se deve justamente às mesmas ciências). Esta classe impede que as ciências operem em uma determinada área que a mantém assim às sombras: a das relações dos homens entre si no exercício da exploração e controle da natureza. Esta atividade da qual dependem os demais, sem novos métodos de pensamento que tinham permitido esclarecer suas relações, através do qual existiam. A nova concepção da natureza não foi aplicada simultaneamente à sociedade. (BRECHT, 1967, p. 187)
\end{abstract}

Brecht produz muitos textos reflexivos sobre o fazer teatral. E, em todos ele promove uma reflexão sobre a postura do homem de teatro como ser social.

Ele propõe o objetivo último do teatro como sendo a diversão, mas observa que esse aspecto se encontrava em franca decadência em seu tempo, portanto era necessária uma revolução para adequar a cena para o prazer do humano. Nos aforismos de 9 a 19, Brecht (1967, p. 190) trata desse declínio:

A nova era científica que se descortina exige novos padrões para a cena e, portanto, para a representação, modificando a natureza do prazer do espectador. "Ciência e arte se encontram nesse ponto: ambas existem para tornar mais simples a vida do homem, a primeira preocupada com a subsistência, a segunda com sua diversão"

Um aspecto significativo da obra de Brecht é que propõe uma reflexão crítica sobre a teoria e prática teatral sua antepassada em relação com a identificação da linguagem do seu tempo. O drama se estabelece no dialogismo entre os homens e a cena científica na qual estava mergulhado - os movimentos estéticos, políticos e sociais do início do século $X X$ - e acaba por gerar a "discórdia". Nesse cenário, o dramático posiciona-se como artificialidade, uma vez que altera o real. No entanto, Brecht não refuta Aristóteles; ele se relaciona criticamente com sua Poética, mas refuta a ideia que nasce da leitura de Aristóteles que promove o teatro como uma caixa de ilusões:

Se a arte reflete a vida, ela o faz com espelhos especiais. A arte não deixa de ser realista por alterar as proporções, mas sim quando as altera de tal modo que o público, ao tentar usar as reproduções na 
prática, em relação a ideias e impulsos, naufraga na vida real. É preciso certamente que a estilização não suprima a naturalidade do elemento natural, mas que o intensifique. (BORHEIM, 1992, grifo meu)

Mas os estudos de Brecht sobre uma mobilização estética para a criação de um teatro que represente o seu tempo começam antes da redação do Organon. Anatol Rosenfeld nos demonstra que uma das primeiras manifestações importantes acerca do teatro épico acontece nas notas acrescentadas à Opera dos Três Vinténs (1928) e à Ascensão e Queda da cidade de Mahagonny (1928/1929). Nelas o autor "se dirige contra o teatro burguês que caracteriza como 'culinário', como instituição em que o público compraria emoções e estados de embriaguez, destinados a eliminar o juízo claro". (ROSENFELD, 1985, p. 149)

Quadro1 - Comparativo entre a forma dramática e a forma épica

\begin{tabular}{|l|l|}
\hline Forma dramática de teatro & Forma épica de teatro \\
\hline $\begin{array}{l}\text { O palco "encarna" uma ação que se } \\
\text { processa }\end{array}$ & Ele narra-a \\
\hline $\begin{array}{l}\text { Enreda o espectador na ação e consome } \\
\text { sua atividade }\end{array}$ & $\begin{array}{l}\text { Dele faz um observador, mas desperta } \\
\text { sua atividade }\end{array}$ \\
\hline $\begin{array}{l}\text { Torna possível que ele tenha } \\
\text { sentimentos }\end{array}$ & Dele exige decisões \\
\hline Proporciona-Ihe vivências & Proporciona-lhe conhecimentos \\
\hline $\begin{array}{l}\text { O espectador é transportado para dentro } \\
\text { de uma ação }\end{array}$ & Ele é colocado em contraposição a ela \\
\hline Trabalha-se com sugestões & Trabalha-se com argumentos \\
\hline Os sentimentos são conservados & São impelidos ao conhecimento \\
\hline $\begin{array}{l}\text { Supõe-se que o homem é algo } \\
\text { conhecido }\end{array}$ & O homem é objeto da investigação \\
\hline O homem imutável & O homem mutável e modificador \\
\hline Tensão voltada ao desenlace & Tensão voltada para o andamento \\
\hline Uma cena serve a outra & Cada cena vale por si \\
\hline $\begin{array}{l}\text { Os acontecimentos decorrem } \\
\text { linearmente }\end{array}$ & Em curvas \\
\hline Natura non facit saltus ${ }^{42}$ & Facit saltus ${ }^{43}$ \\
\hline O mundo tal como ele é & $\begin{array}{l}\text { O mundo como ele será e vem a ser } \\
\text { (processo - nota da autora) }\end{array}$ \\
\hline $\begin{array}{l}\text { O que se põe ao homem como dever } \\
\text { Suas pulsões }\end{array}$ & $\begin{array}{l}\text { O que o homem não pode fazer } \\
\text { Suas motivações }\end{array}$ \\
\hline O pensamento determina o ser & O ser social determina o pensamento \\
\hline
\end{tabular}

Fonte: SZONDI, 2001, p. 116

O Quadro 1 apresenta os comentários de Brecht, aposto ao programa das peças, criando um quadro comparativo entre o dramático e o épico.

\footnotetext{
42 Do latim: A natureza não dá saltos. Refere-se a ideia de continuidade estabelecida no dramático.

${ }^{43}$ Do latim: "dando saltos" (tradução minha). Refere-se às descontinuidades do épico.
} 
Outro aspecto especialmente relevante no teatro de Brecht é a sua dimensão visual, sobretudo no que se refere a um aspecto específico, o gestus, que pode ser entendido, partindo de Pavis (2015, p. 187), como uma característica de usar o corpo tomando a conotação social da atitude das personagens entre si e dentro do seu universo social: "o gestus se compõe de um simples movimento de uma pessoa diante da outra, de uma forma social ou corporativamente particular de se comportar". Em seu estudo Que é o teatro épico?, Walter Benjamin (1987, p. 80) propõe o gestus como essência da cena:

\begin{abstract}
O teatro épico é gestual. Em que sentido ele também é literário, na acepção tradicional do termo, é uma questão aberta. O gesto é seu material, e a aplicação adequada desse material é sua tarefa. [...] o gesto tem duas vantagens. Em primeiro lugar, ele é relativamente pouco falsificável, e o tanto menos quanto mais inconspícuo e habitual for esse gesto. Em segundo lugar, em contraste com as ações e iniciativas dos indivíduos, o gesto tem um começo determinável e um fim determinável.
\end{abstract}

Benjamin entende que a estética do teatro épico corresponde ao seu entorno: "às novas formas técnicas, o cinema e o rádio". O criativo mergulha não mais em uma normativa, mas na reflexão do seu tempo. O palco perde sua instância moral, não se limita a transmitir o conhecimento, mas a conduzir ao conhecimento, à reflexão sobre a dialética ${ }^{44}$ do gesto. Citando a peça Um homem é um homem (1991), ele reflete:

O mesmo gesto faz Galy Gay aproximar-se duas vezes do muro, uma vez para despir-se e outra para ser fuzilado. O mesmo gesto faz com que ele desista de comprar o peixe e aceite o elefante. (BENJAMIN, 1987, p. 89)

A arte constitui-se do amálgama. Com o caminhar da história, o épico, o dramático, o lírico, foram reconhecendo suas similitudes e disparidades, aspectos de completude e negação. Nesse balançar de ondas desembocamos no século $X X^{45}$.

\footnotetext{
${ }^{44}$ A terminologia dialética é bastante importante nos estudos sobre Bertolt Brecht. Como é um conceito amplo e complexo, para o fim dessa dissertação, vou apresentá-lo de forma genérica, como uma tensão formada pela convivência na ambivalência.

${ }^{45} \mathrm{O}$ objetivo desse panorama foi absolutamente didático. Não tenho aqui a intenção de cobrir todo o processo histórico, artístico e político que separa a França do século XVII do Brasil do XXI.
} 


\subsection{O século $X X I$}

Diderot e os dramaturgos do século XVIII, que possibilitaram o desenho do drama burguês e romperam, em parte, com as rígidas estruturas criadas para a tragédia entre os séculos XVI e XVII, a partir de leituras e traduções de Aristóteles, proporcionaram uma mudança estética substancial. Mas toda estética tem implicações políticas, no sentido amplo da palavra, no que diz respeito às relações com o coletivo. Portanto, essa mudança estética mudou a perspectiva da personagem responsável pela escrita dramatúrgica.

Adélia Nicolete (2013), em sua tese de doutorado, na qual trabalhou na mediação de ateliês de criação dramatúrgica, apresenta uma reflexão de Joseph Danan sobre dois sentidos diversos e complementares do que vem a ser o papel do dramaturgo ou dramaturga. Esses dois sentidos correspondem às acepções propostas por Pavis (2015), que exponho aqui:

1. O autor ou autora de dramas (comédia e/ou tragédia); dramatiker, em alemão, e auteur dramatique, em francês. Essa é a noção mais tradicional, relacionada à pessoa que escreve, que cria a dramaturgia;

2. O dramaturg, do alemão, que vem a ter uma função agregada às questões do texto e da encenação, mas não é um criador.

Adélia Nicolete equipara à acepção dramaturg uma expressão brasileira, que é dramaturgista. Quero dar atenção a uma nota de rodapé

No Brasil, o trabalho de dramaturgia pode compreender o suporte à pesquisa, a elaboração de material crítico, de divulgação do grupo/espetáculo, a mediação entre o que é produzido na cena e o dramaturgo entre outros encargos. (NICOLETE ABREU, 2013, p. 76)

Acredito que essa equivalência não seja automática, uma vez que o dramaturgista, no Brasil, é também um criativo. É, muitas vezes, o dramaturgo ou dramaturga que deixa o "gabinete" e passa a trabalhar alimentado pelas improvisações que acontecem na sala de ensaio.

Em sua dissertação de Mestrado, Sérgio Salvia Coelho escreve a partir de sua experiência como dramaturgista na Companhia de Ópera Seca, dirigida por Gerald Thomas, e faz menção à condição criativa do dramaturgista:

Assim, vemos que o dramaturgista pode se dividir em dois, sendo um o "dramaturgo incorporado" à companhia e o outro o "crítico 
incorporado". Seria de se perguntar então se esse termo "dramaturgista" não seria apenas uma nova denominação para um apanhado de velhas funções. (COELHO, 2001, p. 2)

Sérgio Coelho ainda propõe o dramaturgista como aquele que lê uma determinada obra (ou ambiente) e a transforma em cena teatral. Refere-se a Arthur de Azevedo, por teatralizar os acontecimentos no Teatro de Revista, e Ésquilo, "já que promovia uma leitura pessoal de uma fábula mitológica" (COELHO, 2001, p. 3). Lembra ainda que o dramaturgista pode "escapar" ao anonimato, se assinar a obra que reescreve.

De qualquer forma, o dramaturgista é alguém que lê, investiga e escreve. Por ora não irei me ater ao resultado da escrita do dramaturgista.

No verbete do Dicionário do Teatro, Pavis (2015, p. 117) continua com mais implicações sobre a palavra dramaturgo, também no que se refere às suas tarefas. Selecionei algumas:

1. Combinar textos escolhidos para uma mesma encenação;

2. Efetuar pesquisas de documentação sobre e em torno da obra;

3. Adaptar ou modificar o texto;

4. Destacar articulações de sentido e inserir a interpretação;

5. Intervir durante os ensaios como observador crítico.

As tarefas descritas por Pavis, muitas vezes, podem ser adotadas por um encenador ou encenadora que, nesse caso, acumularia funções.

Votando à Danan, referido por Nicolete (2001, p. 3), percebe-se que ele não é excludente quanto à terminologia; ele inclui o sentido de criação (1) e o outro que podemos chamar de sentido mediação (2): "Para Danan, dramaturgia é o nome da parte imaterial do espetáculo, é o pensamento que atravessa a encenação, que a trabalha e se constitui por seu intermédio" (DANAN, Joseph ${ }^{46}$, apud NICOLETE, 2013, p. 77).

Nicolete continua citando o pensamento de Danan no que diz respeito à persona do dramaturgo ou dramaturga:

Danan avisa que não são as máscaras (personas) do autor dramático e do dramaturgista que interessam, "mas a função nomeada dramaturgia que elas encarnam, assim como a carga teórica e prática desta noção" [...] Para Danan, o dramaturgista e toda a sua equipe desempenham a

${ }^{46}$ DANAN, Joseph. Qu'est c ela dramaturgie? Arles. Acters Sud-Papiers. 2010. 
função dramaturgia. (DANAN, Joseph, 2010, p. 6, apud NICOLETE, 2013, p.77)

A personagem que assume a função dramaturgia é o centro nervoso do processo prático de pesquisa da reescritura silenciosa de Fedra, a partir de Phèdre, de Racine. Vamos então a ela.

\subsection{Criadores cênicos}

Durante este projeto de pesquisa, os participantes foram alocados em diferentes funções, ora da dramaturgia ora da cena. Numa leitura coletiva do trecho do texto que será trabalhado, houve uma breve discussão sobre as implicações da cena especificamente (dramaturgia no sentido 2). Um participante individualmente, ou um grupo, se posiciona para recriar, de forma improvisada, as ações necessárias para a tradução daquela cena (improvisação/atuação). Concluída a cena, todos voltam à discussão sobre quais as ações mais adequadas e quais mantiveram a potencialidade do texto matriz (dramaturgia no sentido 2). As improvisações são feitas mais algumas vezes, com diferentes "elencos" (improvisação/atuação), de acordo com as modificações propostas pelo grupo. Escreve-se a didascália correspondente à cena (dramaturgia no sentido 1).

Note-se que a "composição", que faz parte da terminologia empregada para dramaturgia no início desta dissertação, é feita após vários exercícios cênicos. O dramaturgo é um criador, mas, dentro desse processo coletivo, também é ator e crítico. Cada um dos participantes executa todas as seis tarefas elencadas no Dicionário do Teatro (PAVIS, 2015) para o dramaturgo ou dramaturga, e atua como ator ou atriz dentro do processo criativo.

Como a ideia dessa produção de dramaturgia silenciosa está no corpo do ator, escrever o "texto" é uma composição de posturas, gestos, intenções e ações. Uma construção do texto corporal do ator.

Aqui abro um pequeno parêntesis para relatar algo que considero relevante. 
No dia 03 de outubro de 2016, eu estava sentada na plateia do auditório do Instituto de Artes da Unicamp, preparada para assistir à Conferência de Abertura do I Colóquio Internacional de Dramaturgia Letra e Ato, proferida pelo professor Joseph Danan (Université Sorbonne Nouvelle - Paris III), cujo tema era "O texto à prova da cena/ a cena à prova do texto" 47 . O propósito da minha presença ali era justamente minha pesquisa e uma comunicação que faria em uma mesa chamada Texto-Cena.

É importante lembrar que, desde a primeira vez que apresentei o projeto, fui bastante questionada a respeito de se tratar de um projeto de dramaturgia ou de encenação, uma vez que a reescritura passaria necessariamente pela cena, pois levava em consideração a experimentação concreta das ações físicas. Em sua fala, Danan deu conta dessa dúvida, integrando à cena uma personagem com ofício plural: o criador cênico.

O binômio texto-cena, apesar de ser complementar na estrutura teatral, sempre teve uma conotação hierárquica. Ora o texto era o componente principal da estrutura dramática, ora a encenação adquiria essa aura. Em Aristóteles, por exemplo, mesmo refletindo na Poética sobre o dramático e a palavra ação aparecesse muitas vezes ao longo do texto, a ideia de cena, como recurso de representação, era bastante difusa:

... e o espectáculo (opsis), se é certo que atrai os espíritos, é, contudo, o mais desprovido de arte e o mais alheio à poética. $E$ que o efeito da tragédia subsiste mesmo sem os concursos e os actores. $E$, para a montagem dos espectáculos, vale mais a arte de quem executa os acessórios do que a dos poetas. (ARISTÓTELES, 2008, p. 50)

Nesse momento histórico, acreditava-se que o poeta dramático era 0 sujeito único da fala no teatro e que a encenação era elemento acessório.

Danan, durante a conferência, refletiu sobre o pensamento de Bernard Dort ${ }^{48}$ a respeito da mudança do teatro no século XIX, com a invenção da mise en scène, ou seja, quando o diretor de palco, responsável apenas pela organização dos elementos da cena, converte-se em encenador que não apenas

\footnotetext{
${ }^{47}$ A organização do Colóquio gentilmente me cedeu o documento que o professor Danan escreveu para orientar o tradutor da sua conferência.

${ }^{48}$ DORT, Bernard, L'état d'esprit dramaturgique, Théâtre/Public, nº67, janvier-février 1986, p.8
} 
organiza os elementos, mas também os concebe ${ }^{49}$. A partir desse momento, $\mathrm{O}$ texto é subjugado pela "leitura" do encenador ou encenadora. Isso cria um rompimento da "harmonia" que existia entre o texto e a cena e impõe tensão. Dort, inclusive, em seu livro O Teatro e sua realidade (1977), dedica um capítulo à Era da Encenação abrindo com a seguinte afirmação:

"A encenação - declarava Antoine em $1903^{50}$ - é uma arte que acaba de nascer; e nada, absolutamente nada, antes do último século, antes do teatro de intriga e de situações, havia determinado sua eclosão." (ANTOINE, A. apud DORT, B., 1977, p. 61)

E continua dizendo que "a encenação surge como o setor mais privilegiado e mais vivo da atividade teatral contemporânea." (1977, p.61)

Dort fala da vocação comunicativa e coletiva do encenador e do seu trabalho sobre dados pré-exitentes, como o texto ou algo que dispare o processo criativo que resulta na cena.

A partir do século $X X$, mais uma revolução e a cena se realiza independentemente do texto e passa a ser possivel fazer teatro a partir de qualquer dispositivo. A encenação se torna soberana e, muitas vezes, recusa alguns dos pressupostos angulares, como a existência de personagem. Esse estado de coisas se dilata e, aos poucos, reinicia um diálogo reinventado entre texto e cena. A cena contemporânea, no entanto, traz a necessidade não de peças de teatro, mas de textos materiais moldáveis. A dramaturgia é construída em processo, alimentada por um texto base, por meio de um criador cênico sozinho ou na partilha com uma equipe criativa, especialmente no trabalho de improvisação.

No nosso caso, em Fedra, o texto de Racine é usado para alimentar o imaginário dos criadores e das criadoras cênicas, com a finalidade de gerar uma rede de ações, uma estrutura visual-espacial que constitua o drama. O criador cênico é um híbrido dentro da realização da cena e seu processo toma emprestado aspectos múltiplos do fazer teatral. Essa equipe criativa não se ocupa da disposição no espaço, da beleza do figurino, mas ocupa-se com sua

\footnotetext{
${ }^{49}$ Traduzi metteur em scène por diretor de palco e maître de la scène como encenador.

${ }^{50}$ ANTOINE, A., Causerie sur la mise em scène, em Revue de Paris, 01/04/1903.
} 
possibilidade comunicativa. A dramaturgia tecida a partir disso pode ter um registro mesclado, por meio de fotos, vídeos, didascálias ou outros meios. 
Os signos só existem na medida em que são reconhecidos, isto é, na medida em que se repetem; o signo é seguidor, gregário; em cada signo dorme este monstro: um estereótipo. (BARTHES, 1989, p. 15)

Chegamos ao objeto da nossa pesquisa: o texto de Phèdre, de Jean Racine. Na verdade, ele esteve presente desde o início desta dissertação, mas sabemos que a aproximação profunda de um texto teatral é um evento de natureza complexa e pressupõe diferentes aspectos, que vão desde a percepção sensível até a apreciação histórica, sociológica e estética. Uso aqui complexidade na acepção do glossário de Caos Dramaturgia, de Rubens Rewald (2005, p. 110):

\footnotetext{
Sistema rico em informação organizado em níveis hierárquicos que se retroalimentam continuamente. Em sua organização encontra-se uma extrema quantidade de interações e interferência entre um número muito elevado de elementos. Nesse sentido, o todos do sistema não é compreendido pelo mero estudo dos seus elementos. O sistema é irredutível a seus fatores estruturais, pois além dos seus elementos, é fundamental analisar as interações entre eles, e entre eles e o meio externo, para uma melhor compreensão do sistema.
}

Como já foi dito, o referencial teórico da pesquisa foi se desvelando à medida de nossas necessidades, não necessariamente na ordem que aparecem nesta dissertação, porque muitas vezes certos aspectos vinham amalgamados, e a escrita pressupõe certa linearidade. Sendo assim, tento apresentar uma estrutura de desfolhamento, em camadas.

O primeiro sobrevoo foi sobre o contexto estético no qual está inserida a obra de Racine e, em consequência, o social e político, mas dentro de uma perspectiva macro, observando o meio externo. A partir de agora, afunilo a referência, dirigindo-me diretamente ao texto de referência.

A primeira encenação da Phèdre reescrita por Racine aconteceu em 1677, no Hotel Bourgogne, em Paris, ou talvez tenha acontecido no Palais de Versailles, na presença do grande Rei Sol, Louis XIV. As informações apontam para essas duas possibilidades (FONTES, 2007, p. 14) Sobre ela, em um prefácio publicado no ano seguinte, Racine escreve: 
Voici encore une tragédie dont le sujet est pris d'Euripide ${ }^{51}$. Quoique j'aie suivi une route un peu différente de celle de cet auteur pour la conduite de l'action, je n'ai pas laissé d'enrichir ma pièce de tout ce qui m'a paru le plus éclatant dans la sienne. Quand je ne lui devrais que la seule idée du caractère de Phèdre, je pourrais dire que je lui dois ce que j'ai peut-être mis de plus raisonnable sur le théâtre. Je ne suis point étonné que ce caractère ait eu un succès si heureux du temps d'Euripide et qu'il ait encore si bien réussi dans notre siècle, puisqu'il a toutes les qualités qu'Aristote demande dans le héros de la tragédie et qui sont propres à exciter la compassion et la terreur. En effet Phèdre n'est ni tout à fait coupable, ni tout à fait innocente. Elle est engagée par sa destinée et par la colère des dieux dans une passion illégitime dont elle a horreur toute la première. Elle fait tous ses efforts pour la surmonter. Elle aime mieux se laisser mourir que de la déclarer à personne. Et lorsqu'elle est forcée de la découvrir, elle en parle avec une confusion qui fait bien voir que son crime est plutôt une punition des dieux qu'un mouvement de sa volonté ${ }^{2}$.

Essa observação do autor nos elucida alguns aspectos da obra. O primeiro é que sua obra matriz é o Hipólito, de Eurípedes ${ }^{53}$ (EURÍPEDES, Hipólito, 2001). O segundo é a referência ao fato de Phèdre ser uma personagem aristotélica por excelência, o que lhe dá algumas prerrogativas postuladas na Poética (2014) e na composição de poéticas que surgiram nos séculos XVI e XVII e que influenciaram Racine: Phèdreé uma personagem nobre, uma boa mulher, de boa índole e boa herança material; está presa a uma rede de acontecimentos previamente determinada pelos deuses, que incluem as desventuras de seus antepassados e possui uma falha de conduta, que, no caso, é o enamoramento pelo enteado Hippolyte.

\footnotetext{
51 Phèdre veio logo após Iphigénie.

${ }^{52}$ Aqui está outra tragédia cujo assunto é extraído de Eurípides. Embora eu seguisse um caminho um pouco diferente do desse autor para a condução dos acontecimentos, não deixei de enriquecer a minha peça com tudo o que me parecia mais marcante. Porquanto eu lhe deva apenas a ideia da personagem Phedre, eu poderia dizer que devo a ele o que talvez tenha colocado de mais razoável no teatro. Não me surpreende que esse personagem tenha tido um sucesso tão grande nos dias de Eurípides e que ainda o tenha em nosso século, pois tem todas as qualidades que Aristóteles exige para o herói de tragédia e que são capazes de excitar a compaixão e o terror. Na verdade, Phedre não é nem culpada nem inocente. Ela está envolvida, por seu destino e pela ira dos deuses, em uma paixão ilegítima pela qual teme os primeiros. Ela faz todos os esforços para superá-la. Prefere deixar-se morrer em vez de declarar-se a qualquer um. E quando é forçada a revelar-se, confunde-se tanto que deixa claro que seu crime é mais uma punição dos deuses do que um movimento de sua vontade. (tradução minha)

${ }^{53}$ No Hipólito, de Eurípedes, Teseu não é tido como morto. Fedra não declara o seu amor, ela deixa uma carta dizendo que Hipólito a violentara. E ele, após ser dilacerado pelo Monstro, retorna à cena e morre nos braços do pai. Arícia não existe. É justamente o fato de Hipólito ser casto e dedicado apenas à Ártemis que enfurece Vênus. O mote da peça de Eurípedes é totalmente diferente: Hipólito é o herói cuja falha é não creditar honras à Vênus, que, por esse motivo, resolve puni-lo. Fedra está em segundo plano. Ela é o meio pelo qual a deusa age.
} 
Outro aspecto a ser ressaltado nesse prólogo é que, apesar da temática, Racine se libera de qualquer vínculo estrutural com a obra matriz, o que permite que ele exerça um livre exercício de criação em sua reescrita. Ele se ateve apenas à heroína liberando-se dos demais aspectos.

Na preparação dos ensaios de Fedra, a partir do texto de Racine, debruceime sobre o original e sobre as traduções disponíveis para a língua portuguesa. Escolhi duas: a de Jenny Klabin Segall (RACINE, Fedra; Ester; Atália, 2005) - por seu apuro na manutenção da estrutura, inclusive nas rimas e versos - e a de Millôr Fernandes (RACINE, Fedra, 2001), por algo que posso chamar de coloquialidade. Importante que se diga que o principal critério de escolha dessas traduções foi a afinidade. Gostamos delas. Também nos reportamos à obra matriz, Hipólito, de Eurípedes (EURÍPEDES, Hipólito, 2001), sem, no entanto, procurar uma relação direta entre ambas, antes observando o que concerne à reconstituição de sua heroína.

Apesar das inúmeras reescritas a partir da "relação amorosa falhada" entre Fedra e Hipólito, como diria POCIÑA (2016, p. 89), ao longo da história, nosso interesse recaía sobre a fábula elaborada por Racine. Nesse aspecto, o estudo nos orientou a seguir o pressuposto da tragédia aristotélica: "a tragédia é imitação, não de pessoas, mas de uma ação, da vida, da felicidade, da desventura; a felicidade e a desventura estão na ação e a finalidade é uma ação, não uma qualidade." (ARISTÓTELES, HORÁCIO, \& LONGINO, 2014, p. 25). Portanto, perseguimos as ações que caracterizassem Phèdre.

\subsection{A fábula}

Inicio com o preâmbulo de Millôr Fernandes (RACINE, 2001, p. 11), pelo bom humor e pela precisão que the eram peculiares, no texto redigido para 0 programa da montagem de 1986, protagonizada por Fernanda Montenegro e dirigida por Augusto Boal:

Fedra. Já se disse tudo sobre ela nestes últimos três séculos (e muito mais se dirá neste programa): é a tragédia erótica de uma família sexoorientada. Fedra, esposa de Teseu, é irmã de Ariadne (a do labirinto) que já foi apaixonada por Teseu e, abandonada por este num rochedo, que maldade!, se casou com Baco, logo com quem! Ambas, Fedra e 
Ariadne, são filhas de Pasifaé, aquela senhora que se apaixonou por um touro, ora!, ora, e mandou ver, dando a luz o Minotauro. Teseu, o marido de Fedra, antes de casar com esta, conquistou Antíope, rainha das Amazonas, além da já citada Ariadne, depois ganhou Helena aquela mesma, de Tróia - no jogo e teve uma filha com ela. Alguns eruditos discordam dessa versão porque Helena tinha então apenas nove anos, mas se esquecem de que Helena era muito pós-helênica.

Pensando na estrutura mitológica que norteou tanto a obra original como a reescrita de Racine KURY (EURÍPEDES, Hipólito, 2001) propõe o seguinte esquema:

Quadro 2 - Genealogia de Phèdre e Thésée

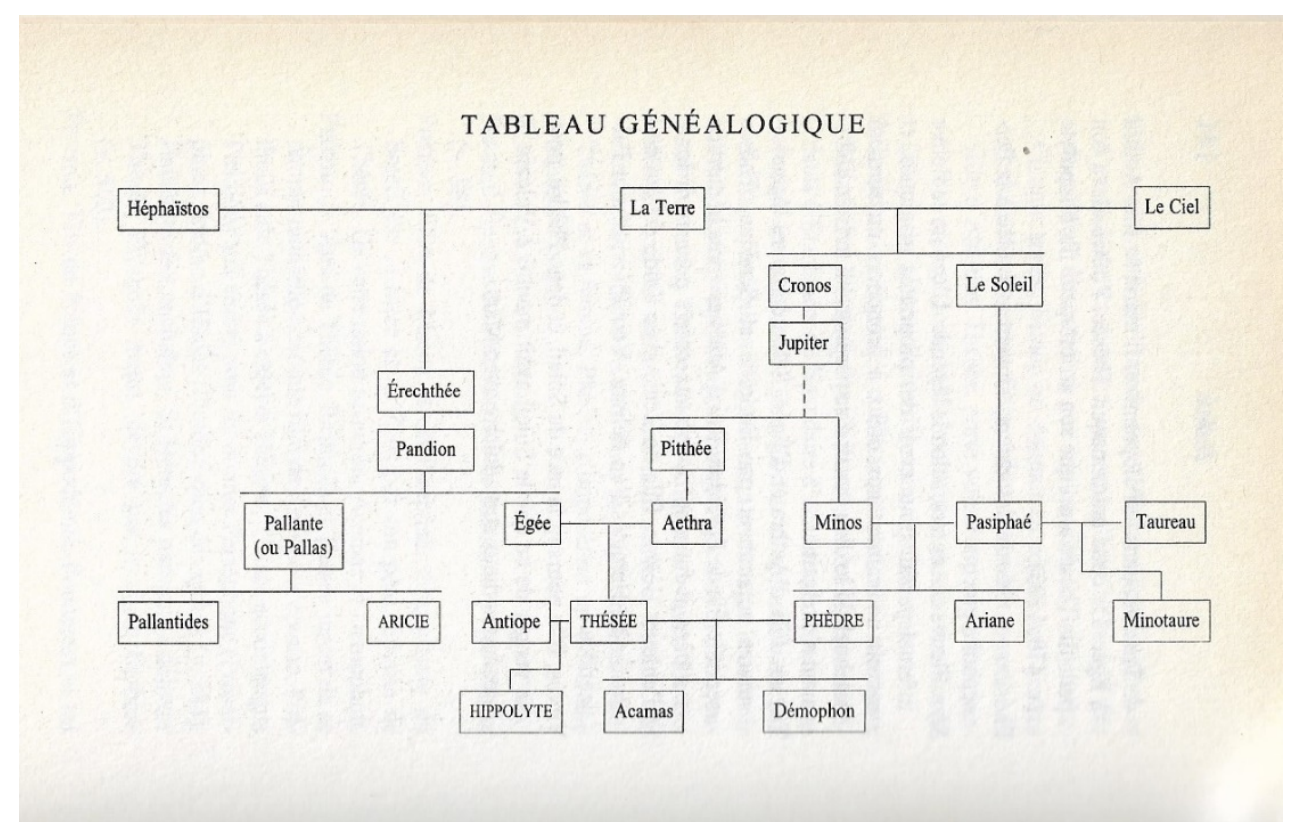

Fonte: RACINE, 2000, p. 142

A leitura do quadro explicita que Teseu, rei de Atenas, era filho do deus Poseidon $^{54}$ e de Aitra; casou-se com Hipólita ou Antíope, a Amazona, dando origem a Hipólito. Após a morte de sua esposa, Teseu casou-se com Fedra.

54 Teseu tem uma dupla paternidade. Egeu, rei de Atenas, tentou ter um filho com várias esposas seguidas, sem sucesso. Sai em uma viagem de Atenas para Trezena e, em seu destino final, deita-se com Aitra, filha de Piteu, por interesse deste que o embriaga. No entanto, Aitra é conduzida por Atená ao leito de Posídon, na mesma noite. "Foi desse encontro, nas horas caladas da noite" que Aitra engravidou. Mas Egeu sempre pensou tratar-se de um filho seu. (BRANDÃO, 1987, p. 151) 


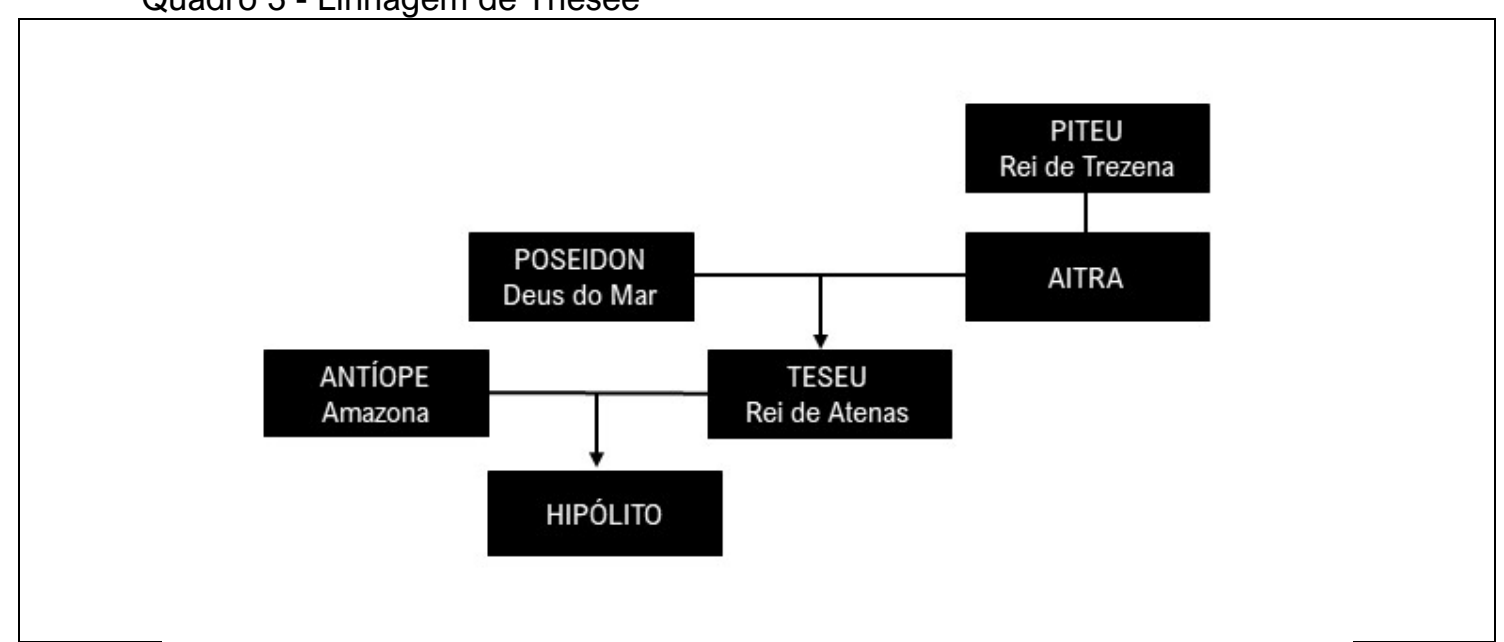

Fonte: EURÍPEDES, Hipólito, 2001

Fedra era filha do Rei Minos, de Creta, e de Pasifae. Casa-se com Teseu e os dois se exilam em Trezena, devido ao fato de Teseu ter assassinado um parente seu, um dos cinquenta Palântidas que queriam tirar o trono de seu pai, Egeu.

Quadro 4 - Linhagem Fedra - Creta

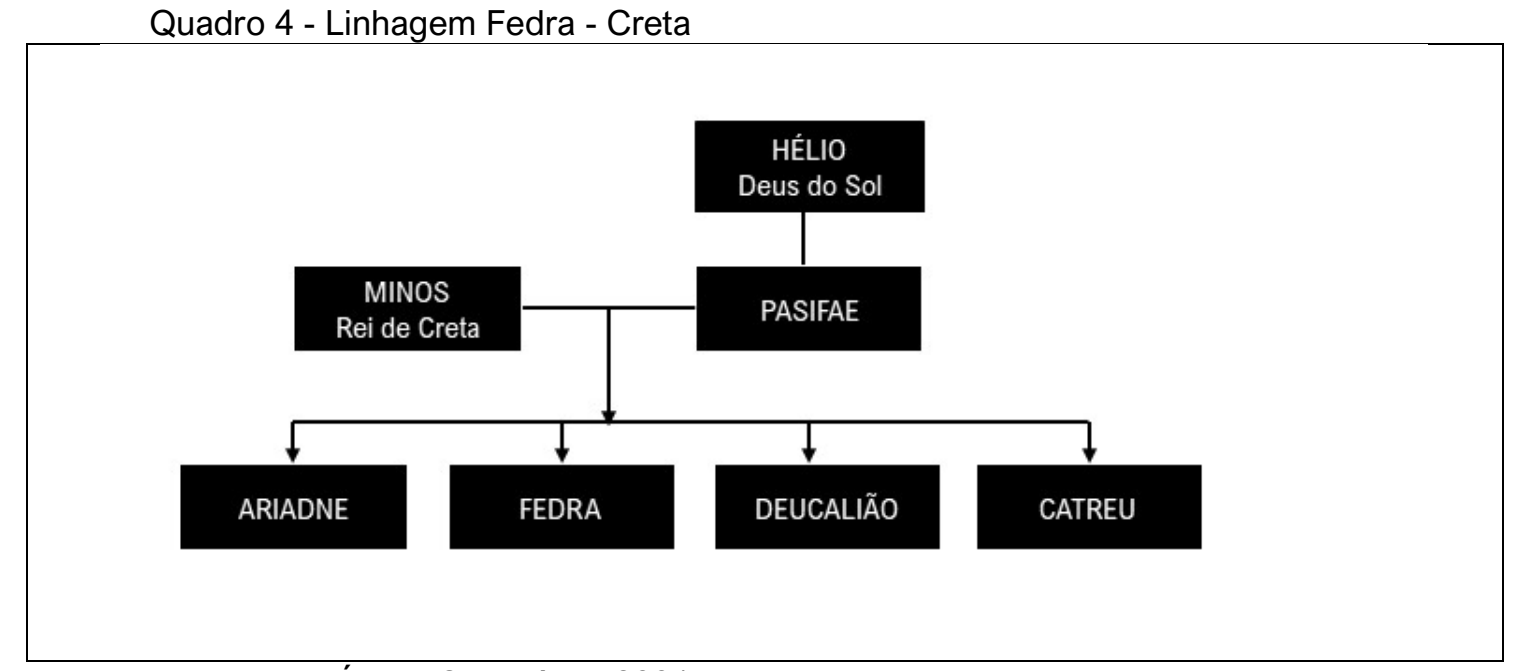

Fonte: EURÍPEDES, Hipólito, 2001

Posto aqui o preliminar à história, passo a resumir a fábula. A sequência que irei relatar baseia-se nas versões de Kury (Eurípedes, 1991), Fontes (2007) e Silva (2015), além das já mencionadas traduções de Phèdre.

A história se passa em Trezena, na Grécia. Phèdre, segunda esposa de Théseé, rei de Athenas, apaixona-se por seu enteado Hippolyte. A culpa por essa paixão faz com que ela prefira a morte a confessar seu amor. No entanto, graças à insistência de Oenone, sua enfermeira e confidente, consumida com o 
sofrimento da ama, Phèdre revela à mulher sua paixão proibida. Essa revelação é feita de maneira indireta: Phèdre cria um jogo quase infantil que faz com que Oenone adivinhe-lhe os sentimentos. Logo começam rumores sobre a morte de Théseé, desaparecido há mais de seis meses.

A sucessão ao trono acarreta uma crise política. Phèdre consulta Hippolyte, mas, na presença do jovem, perturba-se e confessa que o ama. Ele foge, horrorizado.

Logo depois, chega a notícia de que Théseé está vivo. Phèdre desesperase de culpa pelo horror de sua situação. E se Hippolyte falar? Oenone sugere a Phèdre que ela assuma o trono e denuncie Hippolyte por estupro. Phèdre, perturbada, consente.

Oenone denúncia Hippolyte à Théseé, que fica enfurecido com o filho.

Para provar sua inocência, Hippolyte revela seu amor por Aricie, princesa ateniense interditada por Thèseé. O pai não acredita no filho.

Phèdre, envergonhada e arrependida, corre para revelar a verdade ao marido, mas Oenone revela-lhe o amor de Hippolyte por Aricie. Consumida pelo ciúme, resolve calar-se.

Apesar da intervenção de Aricie, Théseé roga a Neptune que puna o filho.

Oenone, banhada em culpa, suicida-se.

Um dragão emerge do mar enviado por Neptune, matando Hippolyte. Phèdre apresenta-se desesperada a Théseé. Confessa sua mentira. Envenenase e morre.

Szondi (2004, p. 112) analisa o caráter trágico da personagem:

Proibido, secreto, irrealizável é o amor de Fedra por Hipólito. O que sua paixão Ihe ordena, a própria Fedra proíbe por fidelidade a Teseu. Em vez de uni-la a seu amado, o amor a divide por dentro. Se ela pudesse renegar seu amor ou sua fidelidade, o dilema estaria superado, o trágico estaria eliminado por meio do compromisso. Mas como não é capaz de abrir mão nem do amor, nem da fidelidade - na medida em que, nos dois casos, essa capacidade se encontra nela e, no entanto, não está em seu poder -, ela é uma heroína trágica.

$\mathrm{E}$, no entanto, essa tragicidade se mostra, em Racine, apenas como o lado exterior de um dilema mais profundo, que se dá não entre o amor e a obrigação, mas simplesmente no interior do próprio amor.' Pois Fedra ama Hipólito não só a despeito de ele ser o filho de seu marido; ama-o também porque ele é filho dele. O que se coloca como obstáculo a seu amor é também a motivação desse amor. 
A tragédia de Phèdre é oriunda da inexorabilidade do destino traçado pelos deuses, mas eles não estão lá, não "dão as caras", não fazem parte do convívio dos humanos desventurosos.

Nesse aspecto, Racine distancia-se da sua matriz, uma vez que, em Eurípedes, a primeira cena é a aparição da deusa Afrodite, vangloriando-se da fama que tem entre seus súditos para, na sequência, mostrar o incômodo que sente pela conduta de Hipólito, jovem casto seguidor de Ártemis, a igualmente virgem deusa da caça. Em Eurípedes, na primeira aparição de Hipólito, o jovem desdenha da deusa do amor, dizendo que não se sente minimamente impelido a prestar-Ihe honras. Rapidamente Afrodite, ela própria, prediz que se vingará, em função dessa conduta de Hipólito, despertando o amor em Fedra, sua madrasta.

Já em Racine (2000, p. 30), a apresentação de Hippolyte é por meio das preocupações com o paradeiro do pai; ele confessa a Théramène que sairá na busca de Thésée:
Ato I, cena 1
HIPPOLYTE
Le dessein en est pris: je pars, cher Théramène
Et quitte le séjour de l'aimable Trézene.
Dans le doute mortel dont je suis agite,
Je commence à rougir de mon oisiveté.
Depuis plus de six mois éloigné de mon père,
J'ignore le destin d'une tête si chère;
J'ignore jusqu'aux lieux qui le peuvent cacher ${ }^{55}$.

No entanto, a tragédia ática prescinde dessa iminência superior, é o deus ou a deusa que determina os fados humanos. Racine retira a divindade da cena, por meio da narrativa de suas ações, como acontece no diálogo entre Phèdre e Oenone:

\section{Ato I, cena 3 \\ PHĖDRE}

${ }^{55}$ Parto: Assim deve ser, Teramenos amigo,

Das plagas de Trezena eu deixo o ameno abrigo.

Na dúvida mortal que o espírito me invade,

Chega a me envergonhar minha inatividade.

Mais de seis meses, já, de meu pai separado,

De um ente tão querido ignoro em tudo o fado.

Ignoro até as regiões que podem ocultá-lo. Tradução de Jenny Klabin Segall $(2005$, p. 3) 
Ô, haine de Vénus! Ô fatale colère!

Dans quels égarements l'amour jeta ma mère!

OENONE

Oublions-les, Madame. Et qu'à tout l'avenir

Um silence éternel cache ce souvenir.

PHĖDRE

Ariane, ma soeur! De quel amour blessée,

Vous mourûtes aux bords où vous fûtes laissée!

OENONE

Que faites-vous, Madame? Et quel mortel ennui

Contre tout votre sang vous anime aujourd'hui

PHÈDRE

Puisque Vénus le veut, de ce sang déplorable

Je péris la dernière, et la plus misérable.

OENONE

Aimez-vouz?

PHÈDRE

De l'amour j'ai toutes les fureurs. $(2000 \text {, p. } 44)^{56}$

Phèdre narra a ação de Vénus/Cípris quando se refere à sua mãe (Pasifae) e aos desvarios a que o amor a reduziu, referindo-se ao fato de a rainha ter-se apaixonado por um touro e pedido ao arquiteto Dédalos que engendrasse uma vaca de madeira para que ela tivesse a conjunção carnal da sua paixão ${ }^{57}$. $\mathrm{Na}$

${ }^{56}$ FEDRA

De Vênus oh fatal ódio! Oh implacável ira!

A que desvaire o amor minha mãe reduzira!

OENONE

Ah! Pr'a sempre, senhora, ante todo o universo,

Fique esse atroz segredo em fundo olvido imerso!

FEDRA

Ariadne, minha irmã! De que amor lacerada,

Morrestes sobre a borda onde fostes deixada!

OENONE

Senhora, que fazeis? Qual é a mortal desdita,

Que contra o vosso sangue hoje assim vos incita?

FEDRA

Já que Vênus o que, de um sangue deplorável

Pereço a última, eu, como a mais miserável!

OENONE

Amais então?

FEDRA

Do amor tenho os fatais furores. Tradução Jenny Klabin Segall (2005, pp. 14-15)

${ }^{57}$ A rainha Pasifae, filha do deus Hélio, o Sol, é vítima da ira de Posídon contra Minos, seu esposo. Em um acordo pelo reinado de Creta, Minos pede que Posídon faça com que um Touro surja do mar. $\mathrm{O}$ deus atendeu ao pedido com a condição que o animal seria sacrificado em seguida. No entanto, diante da beleza do animal, Minos não realiza a sua parte no acordo. Posídon evoca 
verdade, Racine narra o resultado da ação gerada pela cólera dos deuses, o desvario, mas não a ação propriamente dita.

Eurípedes usa semelhante recurso ao narrar a morte de Hipólito, como uma forma de adiamento, ou mesmo de suavizar, a apresentação do pathos ${ }^{58}$. No entanto, o que segue é a revelação da inocência de Hipólito pela boca da deusa Ártemis, a quem Hipólito é devotado, que se encarrega de expor a Teseu o estratagema de Fedra. Após a explanação da deusa, Hipólito reaparece ensanguentado para morrer nos braços do pai.

Em Racine (1677, p. 77), é Phèdre que revela a verdade (V,7): “Le Ciel mit dans mon tel une flamme funetre/La detestable Oenone a conduit tout le reste." 59

Apesar do recurso estético na condução trágica de Racine, evidencia-se também a circunstância política de um autor expoente do classicismo francês.

\subsection{Escrever o silêncio}

Iniciei o primeiro capítulo tentando entender quais os elementos constitutivos da dramaturgia e o que ela implica. Em determinado momento, observei que estava centrada na composição e citei Eugênio Barba (2012, p. 66), referindo-se ao "trabalho das ações no espetáculo". Segundo ele, a reescritura, antes de ser uma composição, é uma decomposição, porque, em primeiro lugar, há a necessidade de desconstruir, decupar a obra matriz a fim de compreenderIhe a essência para iniciar um novo processo de criação a partir dessa leitura.

Entendendo que decupagem, aqui, traz uma parte específica da conceituação proposta por Pavis (2015, p. 86) - "tomada de consciência do modo de fabricação da obra e do sentido" -, o olhar investigativo estará voltado para os silêncios dos quais a obra de Racine é constituída.

Gosto de escrever de forma circular, resgatando, de tempos em tempos, sentenças, conceitos, ideias, para que tudo permaneça vivo e carregue uma

Afrodite que sopra uma paixão irresistível pelo Touro no coração de Pasifae. (BRANDÃO, 1986, p. 61)

58 "Acto destruidor ou doloroso tal como as mortes em cena, grandes dores e e ferimentos e coisas deste gênero". (ARISTÓTELES, 2008, p. 21)

59 O céu colocou em minha alma uma chama fúnebre/A detestável Oenone conduziu o resto. (tradução minha) 
Na primeira aparição, o gesto de representação de Fedra é de cansaço, mas não o cansaço de uma mulher que esteve durante muito tempo na execução de um trabalho braçal, e sim o cansaço que sua condição de rainha lhe impõe, inclusive, o uso de certos adornos. Ela se ocupa em desfazer, com uma mistura de nojo e aflição, tudo aquilo que estabelece a sua persona.

O fortalecimento do gesto se dá na contracena, que se posiciona como uma contradição. Para o fortalecimento do caráter excessivo do herói, é necessário que ele tenha um par que o contraste ${ }^{61}$. Enone é o par de Fedra, como é possível visualizar nas figuras 3,4 e 5 .

Figura 1 - Fedra (Adriana Azenha) tem os cabelos arrumados por Enone (Eduardo Bartolomeu)

Fonte: Fotografia de processo. Autoria Geraldo de Lima.

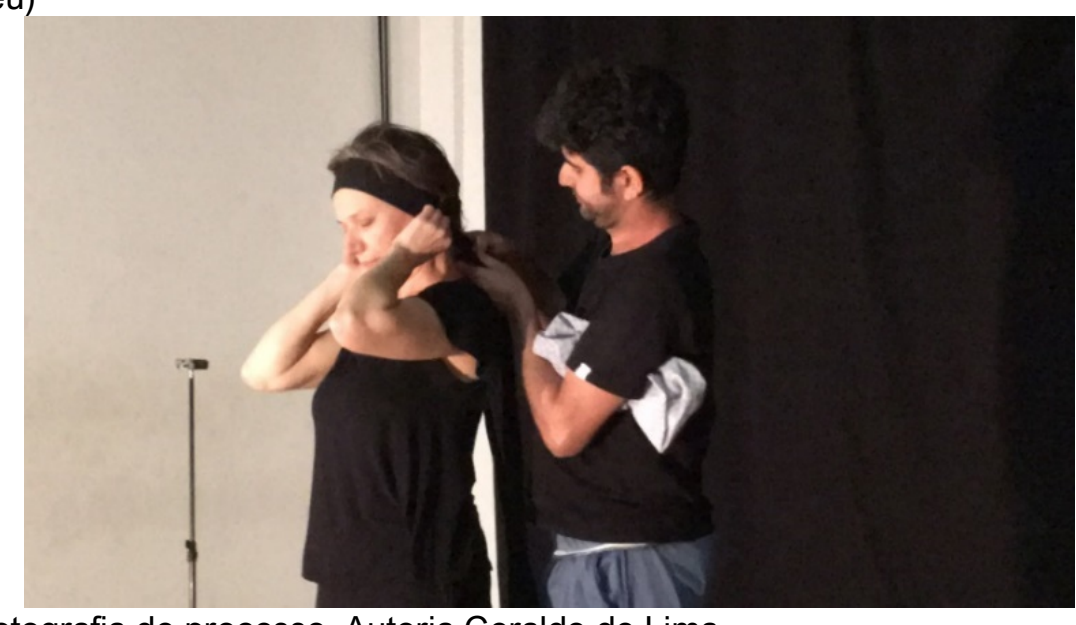

61 Orientação do Professor Dr. Sérgio de Carvalho durante as aulas de Dramaturgia 3 para a graduação, das quais participei, dentro do Programa de Aperfeiçoamento do Ensino (PAE). 
Figura 2 - Fedra (Miriam Lima) é acariciada por Enone (Rogério Favoretto)

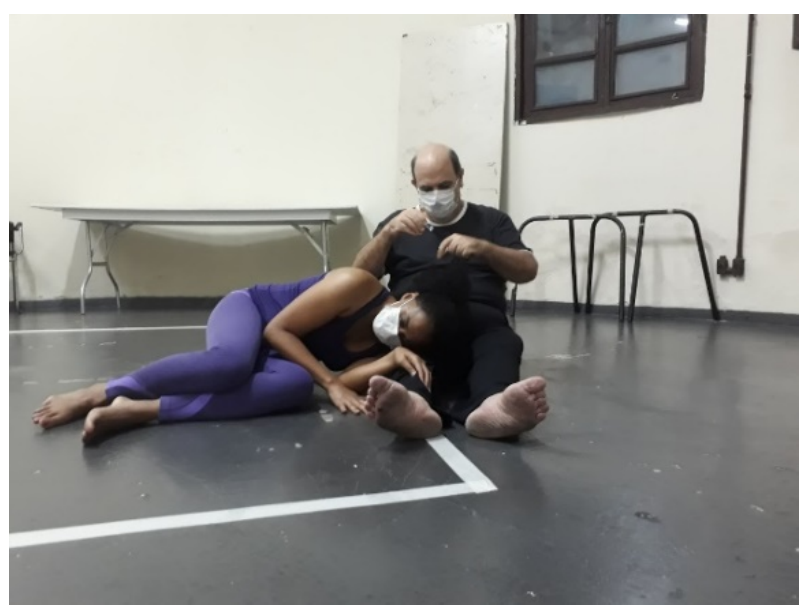

Fonte: Fotografia de processo. Autoria minha.

Figura 3 - Fedra (Jany Canela) é abraçada por Enone (Adriana Azenha)

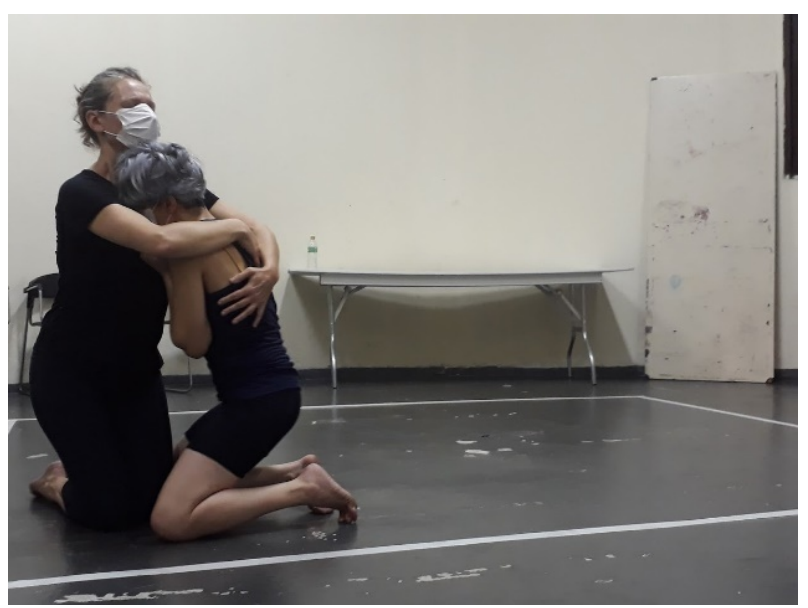

Fonte: Fotografia de processo. Autoria minha.

Entre Enone e Fedra há uma diferença social grande, portanto, o gesto deve ser significativo na sua sutileza.

Estou, desde o início desta dissertação, usando palavras-signo, mas chegou o momento de atribuir valor a elas. Para isso, vou lançar mão de uma explicação muito didática, feita por Roland Barthes ${ }^{62}$ em Crítica e verdade (2007, p. 41-49), segundo a qual, os signos só existem em relações que podem ser de três tipos.

${ }^{62}$ Essa perspectiva de elucidação do signo tem objetivo didático, uma vez que esta não é uma pesquisa sobre semiologia. Estou consciente da afirmação de Anne Ubersfeld (2013) a respeito da inviabilidade de redução do fenômeno teatral a um sistema de signos, uma vez que se trata de um acontecimento complexo. 


\section{Relação simbólica}

O primeiro tipo de relação é o signo reconhecível por convenção, como por exemplo a coroa, que simboliza a realeza. É um símbolo instituído, mas, por repetição, claramente reconhecível.

\section{Relação paradigmática}

Nesse tipo de relação, compara-se um elemento com outro que tenha diferença necessária e suficiente para operar uma mudança de sentido. A cadeira de um "patrão", em um escritório, por exemplo, é um pouco maior e um pouco mais alta que as outras. Se há apenas essa cadeira, não existe uma significação especifica além da sua função de cadeira, mas quando em comparação com as demais cadeiras, ela expõe sua significação hierárquica.

\section{Relação sintagmática}

São associações passageiras, mas significativas, que se unem dentro do próprio discurso, no caso do gesto, do não verbal. Colocar um vestido junto com uma calça, por exemplo, não guarda um significado especifico, mas estabelece uma relação pela proximidade dos objetos.

Segundo Barthes (1989), a busca na elaboração do gesto significativo que represente determinada personagem está direcionada à constituição de sintagmas, que são formas mais sutis, não tem uma significação convencional, como na relação simbólica, mas, por repetição, começa a ser reconhecível ao espectador.

Fedra quer se desfazer de sua condição de rainha, assim como quer se desfazer da condição de esposa de Teseu. Sua postura deve estar de acordo com o que simboliza uma rainha: uma coluna muito reta, um sorriso muito discreto, um olhar altivo e distante. Mas não é apenas a relação simbólica que deve ser representar; há a relação com aqueles que devem se curvar diante da rainha, portanto há esse desconforto com a posição social, que pode se apresentar de forma discreta, mas que pela constância acaba por evidenciar esse caráter antitético. 
Essa compreensão dos signos representativos deve levar em conta o caráter complexo da construção teatral e não apenas os aspectos internos da personagem. A leitura do texto precisa considerar não apenas os aspectos que se apresentam diretamente como também aqueles subjacentes: Fedra não é apenas a madrasta que ama o enteado, é uma mulher que quer se libertar de uma condição.

Assim, nesse processo de busca pelo gestual, há que se considerar a base, a estrutura na qual o gesto será elaborado: o corpo do ator e da atriz. Sobre isso, Dario Fo (1998, p. 60-63) diz algo essencial: "todos os corpos já têm um gestual e um ritmo que significa". Mesmo que não se faça nada, um ator ou atriz parada em cena já estabelece uma série de relações dos três níveis desenhados por Barthes. No processo de compreensão e construção do gesto significativo de cada personagem, há a necessidade do reconhecimento do seu próprio corpo, observando ritmos, gestos, dinâmicas porque tudo significa. A construção desse gestual de representação deve acontecer em diálogo com o corpo do ator e da atriz. Não há uma única Fedra, assim como não há uma única Enone. $\mathrm{O}$ caráter do personagem dialoga com o corpo do ator ou atriz, e assim, nasce o gestual de Fedra ou de Enone para aquele ator ou para aquela atriz.

Dentro de uma linha de produção, como o teatro musical feito por meio das grandes franquias, é possível considerar que o gestual da personagem está previamente estabelecido em uma partitura, e é exatamente por isso que os atores e atrizes são selecionados pelo physique du rôle, porque isso possibilita realizar aquele gestual específico.

Portanto, em uma composição artesanal que contempla as particularidades de cada criador ou criadora cênica, é importante o reconhecimento e a revelação das singularidades.

\subsubsection{A ação}

Antes de prosseguir, é preciso alguns esclarecimentos sobre o conceito de ação da personagem. 
A representação por atores de uma ação que, a partir de uma situação dada, opõe dois ou mais personagens que evoluem segundo as leis de sua própria lógica.

O que é uma ação? Segundo o Dicionário Aurélio:

a.ção [Lat. Actione] sf. 1. Ato ou efeito de agir, de atuar, atuação, ato. 2. Manifestação de uma força, uma energia, um agente, atua sobre o outro. 4. Capacidade de agir. 5. Comportamento, procedimento. [...] (FERREIRA, 2010, grifo meu)

Trazendo a acepção 5 do verbete para a situação da personagem Phèdre:

Ato I, cena 3

OENONE

Parlez: je vous écoute.

PHĖDRE

Ciel! Que lui vais-je dire? Et par où commencer?

OENONE

Par de vaines frayeurs cessez de m'offenser ${ }^{63}$. (2000, p. 43-44)

Enone descreve claramente sua ação e a ação de Fedra: "Fala, eu escuto." A ação de ouvir e falar estão na base desse diálogo, no entanto, há uma segunda camada, que é o comportamento, o procedimento, que se distingue por três aspectos: quem, como e por que: Fedra fala como fala, dessa forma meio reticente e truncada, sem ir direto ao ponto porque está com medo do que tem a revelar, uma vez que para quem ela é, ou seja, uma rainha - ou melhor, a esposa de um rei - e madrasta de Hipólito, sua revelação é um infortúnio. Quanto a Enone, é uma criada, que ouve por imposição do cargo e porque se interessa por Fedra; uma leitura possível é que se enamore dela.

O que eu quero dizer com isso é que não há ação sem contexto. Há inúmeros estudos de Bertolt Brecht sobre contexto, mas há um trecho específico

${ }^{63}$ ENONE

Fala: eu escuto.

FEDRA

Céus! Como dizer? Por onde começar?

ENONE

Por favor, basta de me ofender com esses temores fúteis. Tradução: Jenny Klabin Segall (RACINE, 2001, p. 27-28) 
no Escritos sobre teatro, no qual ele diz que na atuação deve-se mostrar "o conhecimento das relações humanas"64 (BRECHT, 1970, p. 37) e esse conhecimento sempre partirá da perspectiva de quem o representa, de como esse criador ou criadora cênica se relacionam com as personagens representadas. A ação é sempre simples e reduzida: ouvir, falar, sentar, pegar uma cadeira, comer, açoitar, no entanto, o contexto no qual ela está inserida cria a dramaticidade da ação.

No grupo, improvisamos essa cena com dois pares diferentes de atores: primeiramente com Rogério Favoretto (Enone) e Jany Canela (Fedra), depois com Eduardo Bartolomeu (Enone) e Adriana Azenha (Fedra). Mais adiante, irei me referir a aspectos específicos do que foi descoberto, por ora detenho-me na reflexão sobre a peculiaridade da cena atuada pelas duas duplas.

Figura 4 - Enone (Rogério Favoretto) descobre o amor de Fedra (Jany Canela) por Hipólito

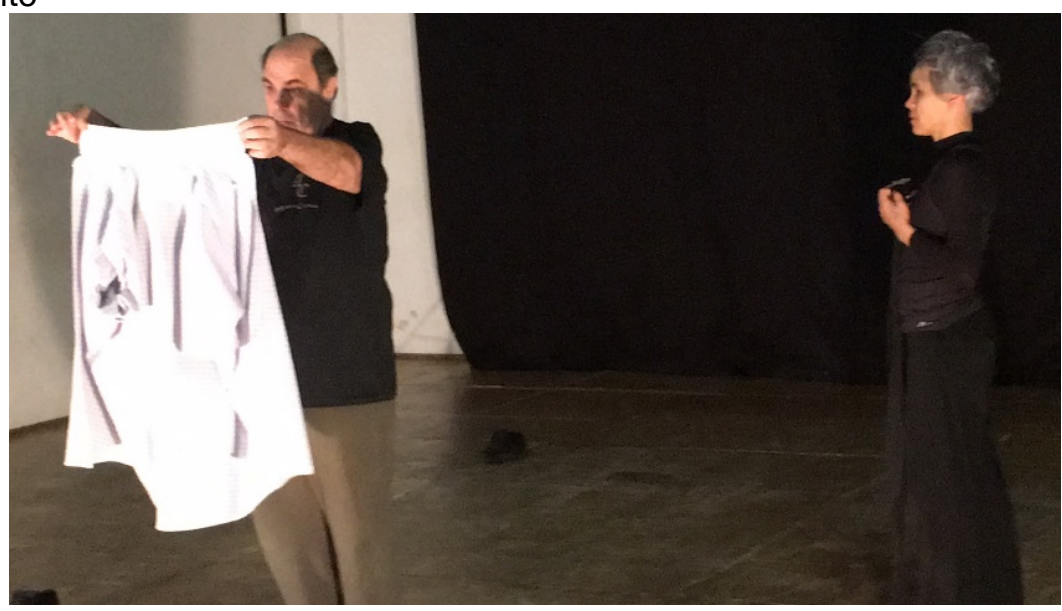

Fonte: Fotografia de processo. Autoria Geraldo Lima

${ }^{64}$ Tradução minha, a partir do espanhol. 
Figura 5 - Fedra (Adriana Azenha) é flagrada se masturbando com a camisa de Hipólito por Enone (Eduardo Bartolomeu)

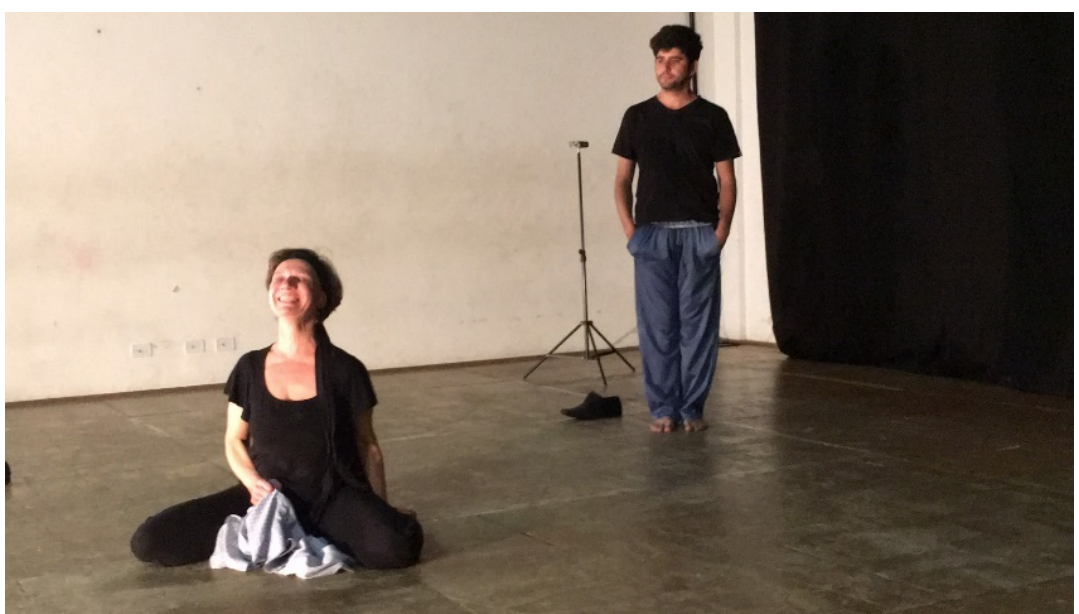

Fonte: Fotografia de processo. Autoria Geraldo Lima.

Rogério Favoretto, ao ver ${ }^{65}$ Jany Canela revelar o amor de Fedra por Hipólito, permaneceu em atitude fleumática; sua reprovação era visível, no entanto, sem grandes manifestações, apenas a expressão do rosto trazia indícios disso; o corpo um tanto retesado denotava repúdio. Isso provocou uma reação de certa timidez e desconcerto em Jany. Tanto Jany como Rogério mantiveram a altivez e uma frieza na cena.

Eduardo, por sua vez, colocou-se em atitude de admoestação explícita, seguindo-se de uma sequência de ações na qual ajeitava, com um tanto de rudeza, as roupas de Adriana, e penteava seus cabelos, de forma rápida e bruta.

Ao final das improvisações, essas duas Enones foram apelidadas de Enone Governanta, a fleumática, e Enone Diarista, intrometida e rude.

Só isso é um universo: desde o desenho diferente das relações em cada par de improviso, das ações de "escutar" e "falar", até a percepção individual das personagens e os apelidos gerados em função disso. Pelo fato de não haver palavras que orientem a decodificação dos signos pelo espectador, cada gesto expande a sua significação. Nesse exemplo, temos duas representações quase antagônicas do que vem a ser a figura de Enone. As diferenças são muito

${ }^{65}$ Como se trata de uma dramaturgia do silêncio, não houve escuta de palavra, mas houve a observação de uma ação. Tratarei da forma de realização dessa cena no próximo capítulo, devido a suas particularidades em relação ao silêncio. 
explícitas, o que é muito bom, porque acabam por evidenciar o quanto de conteúdo pragmático permeia cada ação.

Isso nos reporta à próxima instância: a situação.

\title{
3.1.2 A situação dramática
}

Parto da conceituação de Etienne Souriau (1993, p. 35):

\begin{abstract}
Uma situação dramática é a forma particular de tensão inter-humana e microcósmica do movimento cênico. Todo o teatro está nesse jogo alternativo de forças nucleares, ora caminhando paralelamente, ora apoiando-se umas nas outras, para depois ver jorrar do interior desse próprio apoio o impulso para a frente que a transporta para o futuro, quando readquirirão diferentes configurações, nas quais se iluminará, por assim dizer, a tensão nuclear dessas forças destinadas a infletir-se de novo rumo ao futuro pela ação.
\end{abstract}

A importância da situação dramática é compreender as relações e a direção das forças que regem as personagens. Dario Fo (1998, p. 152-156) tem uma forma muito pitoresca de explicar esse conceito: ele chama três mímicos voluntários e propõe que mimem ${ }^{66}$ uma sequência de ações. Vou resumi-la aqui, mantendo a primeira pessoa que ele emprega, para dar a mesma ideia de instrução de jogo, mas sem fazer uma citação direta, porque é um trecho muito longo, e nem tudo nos será necessário:

Vamos lá, vou pedir para que vocês realizem algumas ações, mas não vou contar a situação, preciso que mimem às cegas. Cada um, na sua vez, entrará pelo fundo do palco denotando preocupação, tensão e cautela. Olha ao redor. Ali existe um muro e ali uma porta. Tenta abrir a porta, mas ela está fechada. Tenta subir no muro, para ver se há algo do outro lado, em vão, porque é muito alto. Então se afasta e se dirige para o outro lado do palco, tentando abrir uma porta que há ali. Um, dois, nada. Também está trancada. A angústia aumenta. Dirigese para o fundo do palco, olha para a esquerda e para a direita procurando algo ou alguém, mas não há nada. Vira-se e, finalmente, uma esperança! É maravilhoso! Mas espere. Há algo perturbador, aliás, algo que o aniquila, fazendoo cair de joelhos.

\footnotetext{
${ }^{66}$ Façam a mímica.
} 
Fo orienta pacientemente os mímicos para garantir a realização precisa da sequência de ações. Depois, pede para que saiam e confidencia algo com a plateia, que não poderá ser compartilhado com os mímicos. Ele estabelece uma situação diferente para cada entrada:

I. Homem brigou em um bar e deu uma facada no amigo. Foge e é perseguido por todos os outros companheiros desejosos de lhe dar uma lição. Ele tenta escapar pela porta, tenta pular o muro, tenta outra porta e, quando se vira, vê uma saída livre, mas logo em seguida, os amigos postam-se diante dele, eliminando as possibilidades de fuga.

II. Ele é abandonado pela mulher após uma briga terrível. Abatido, sai a sua procura. Deseja se reconciliar. Empurra todas as portas, mas não a encontra. De repente, parece ter vislumbrado a amada ao longe. "Sim, é ela sim... é ela! Mas está na companhia de outro homem, lançando-se apaixonadamente em seus braços." Em sua impotência e decepção, cai agachado.

III. Sujeito "atormentado por exigências corporais prementes". Desesperado, vê que a porta do banheiro público está trancada, tenta outra porta e nada. De repente, alivia a sua vontade, deixa-se “esvair...agachado...na liberação”.

A plateia, presente ao exercício proposto por Fo, tem reações diferentes para cada situação: na primeira (bar), há "risadas e aplausos do público"; Fo não comenta a reação para a segunda situação (amor) e, na terceira situação, o "público explode em grandes gargalhadas e aplausos. Quando o rapaz desconsolado se agacha, inconscientemente, para defecar... irrompe um imenso fragor."

A situação descreve o contexto da cena, que é construído previamente e interfere diretamente na emoção do espectador. No trecho de Fedra no qual ela revela à Enone seu amor por Hipólito, é necessário que a situação seja conhecida do espectador para que ele compreenda quais as forças ali implicadas. 
Ter a consciência da situação implicada não é uma tarefa óbvia no texto dramático, porque as forças que atuam no texto se movimentam e o teatro também não é feito apenas do texto, sobretudo porque estamos falando de uma dramaturgia do silêncio.

Existem algumas formas de se reconhecer as estruturas de forças das quais se constitui um texto teatral; aqui aponto dois modelos diferentes e complementares para aplicar ao texto de Racine.

O primeiro modelo foi desenvolvido por Etienne Souriau (1993) e baseiase nas funções dramatúrgicas. O segundo modelo tem origem em Algirdas Julius Greimas ${ }^{67}$, citado e ampliado por Anne Ubersfeld (2013) e trabalha os modelos actanciais. Eles têm alguns pontos de discordância e de convergência.

\section{As situações dramáticas}

Etienne Souriau publica, em 1950, uma obra na qual abre a pesquisa das situações em um leque amplo, olhando para o texto teatral não pelo aspecto psicológico das personagens ou pela análise de ações, mas por um movimento característico por desejos, crenças, forças e valores:

[...] Certo número de funções dramáticas elementares, que esboçam as linhas de força da situação, podem reunir-se ou separar-se caleidoscopicamente, encarnando-se nessa ou naquela individualidade do microcosmo cênico. E o único caminho que se abre para uma análise e uma combinatória, ao mesmo tempo penetrantes e eficazes, é inventariar primeiro as principais das grandes funções dramatúrgicas. (SOURIAU, 1993, p. 49)

Dessa forma, as funções dramatúrgicas vêm a ser "o modo específico de trabalho e situação de uma personagem: seu papel próprio enquanto força num sistema de forças." (SOURIAU, 1993, p. 52)

A postulação de Souriau estava localizada justamente no fato de apresentar a complexidade das personagens e não apenas uma única força que as conduzisse, portanto, a análise se dá não por personagem, mas pela força, que pode ser plural em uma única personagem. Para tanto, Souriau estabelece essa relação por meio de um sistema de signos representados por temas do

${ }^{67}$ Greimas, Algirdas Julien. 1966. Sémantique structurale: recherche de méthode. Paris: Larousse. 
horóscopo que atuam na construção do "céu dramático" em determinado momento. Apresento aqui os signos e suas forças dramatúrgicas (SOURIAU, 1993, p. 58-104):

\section{$\delta$ \\ O Leão ou a Força temática}

É a personagem sede ${ }^{68}$, ou presa da força orientada, que gera a situação dramática. É ela que dá origem a todos os acontecimentos. Ela encarna, "representa e põe em jogo a força que gera toda a tensão dramática presente." (SOURIAU, 1993, p. 61)

Phèdre é $\Omega$, uma vez que é, ao mesmo tempo, presa e hospedeira de seu amor por Hippolyte, e esse amor é a origem do conflito existente na tragédia.

$\odot$

O Sol (ou o Representante do Valor, do Bem cobiçado por $\Omega$ )

Essa força não se encontra necessariamente encarnada em um personagem e nesse fato se localiza a potência do estudo de Souriau: não se trata da análise de personagens, mas da compreensão de um movimento macro em relação à peça.

Hippolyte é o $\odot$ almejado por Phèdre $\Omega$

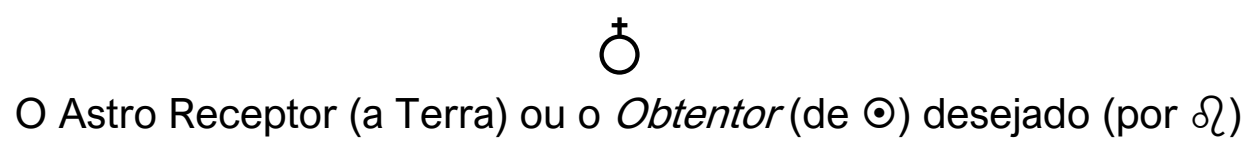

Seguindo a lógica das funções dramatúrgicas desenhadas por Souriau, Aricie é $\circlearrowleft$,uma vez que é ela que recebe o amor de Hippolyte $(\odot)$ de Phèdre $(\Omega)$.

\footnotetext{
${ }^{68}$ Sede no sentido de sediar, hospedar.
} 


\section{○'}

Marte ou o Oponente

É o que se interpõe entre $\Omega$ e $\odot$, o obstáculo. "Não haveria drama, entretanto, se a tendência não se chocasse com algum obstáculo." (1993, p. 67)

No texto de Racine há uma composição dinâmica de $\sigma^{\prime}$, porque temos três personagens que o encarnam: Thésée, Aricie e Hippolyte.

Thésée pelo fato de ser marido de Phèdre, sua existência gera tensão em oposição ao desejo da heroina.

Aricie, porque, uma vez que é amada por Hippolyte, interfere nos caminhos que possibilitariam que Phèdre o conquistasse. Enquanto acreditava que Hippolyte fosse virgem, Phèdre não duvidava da possibilidade da consumação do amor de ambos. É inclusive a força de oposição da existência de outra mulher que promove a fúria que faz com que Phèdre aceite mentir.

Hippolyte, por recusar o amor de Phèdre.

Phèdre também é Marte de Phèdre porque teme, revolta-se, culpa-se e envergonha-se de seu amor.

\section{$\Omega$ \\ A Balança ou $o$ Ȧrbitro da Situação (o atribuidor do Bem)}

É aquele que, dentro do microcosmo dramático, tem a atribuição de distribuir a felicidade ou a infelicidade.

Hippolyte é o único capaz de fazer isso. $O$ desejo de $\Omega$ reside nele, ele é o próprio desejo e, por isso, o único que pode distribui-lo, a $\Omega$.

\section{C*}

A Lua ou o Espelho de Força (o Adjuntor)

Esse é o papel de co-interessado, cúmplice, auxiliador e salvador.

Oenone é $₫ *$ de Phèdre $\Omega$.

Thèramène é $C^{*}$ de Hippolyte. 
A riqueza desta análise, a partir das funções dramáturgicas, é que elas são cambiáveis. Há muitas combinações possíveis dentro de uma mesma trama. Há um desenho macro, mas muitas outras relações se estabelecem.

Por exemplo, quando a peça inicia, o diálogo entre Hippolyte e Théramène é a situação (I,1), na qual Hippolyte se mostra ansioso pelo paradeiro de Thèsèe; Hippolyte é o Leão e Thèsèe é seu Sol. Balança é encarnado pelo destino, que permitirá que o rei volte ou não. Essa não é a força propulsora da tensão dramática que determina a tragédia, mas é o que mobiliza essa situação em particular.

Em outra situação $(I I, 2)$, as personagens se encontram em câmbio de funções. Quando Hippolyte se declara à Aricie, ele é Leão e Thèsée seu Marte.

\subsubsection{Modelo actancial}

A professora Anne Ubersfeld, em seu livro Para ler o teatro (2013), propõe um modelo de análise na relação texto-representação, baseado no proposto por Greimas que, por sua vez, segue os passos de Souriau, isto é, "apresenta soluções e estabelece uma série de unidades hierarquizadas e articuladas: actante, ator, papel, personagem; o que permite encontrar as mesmas unidades no nível da escritura e no nível da representação. (GREIMAS ${ }^{69}$, A.J. apud UBERSFELD, 2013, p. 34)

A noção de modelo, esquema ou código actancial foi adotada em investigações semiológicas e dramatúrgicas para visualizar as principais forças do drama e seu papel na ação. Apresenta a vantagem de não mais separar artificialmente personagens e ação, se não revelar a dialética e o passo progressivo de um para o outro. Seu sucesso é devido ao esclarecimento dado a respeito dos problemas da situação dramática, a dinâmica das situações e personagens, a aparência e a resolução de conflitos.

O modelo actancial, por outro lado, fornece uma visão diferente e ampliada de personagem. Este não é mais assimilado para um ser psicológico ou

69 GREIMAS, A.J. Les actantes, les acteurs et les figures em Sémiotique narrative et textuelle. Paris, Larousse, 1966. 
metafísico, mas é considerado como uma entidade que pertence ao sistema global, que vai da conformação do actante (estrutura narrativa profunda) para o texto.

O salto qualitativo é que Greimas propõe uma trança entre texto e representação, compreendendo a tridimensionalidade da dramaturgia, que é também espacial e visual. Outro dado é que é moldável, "não é uma forma, é uma sintaxe ${ }^{70 "}$ por isso capaz de ampliar as "possibilidades textuais".

O actante se define não por uma personagem, mas pelos princípios e os meios da ação: um desejo, um dever, um saber, de natureza e intensidade variáveis. Ele pode ser uma abstração, uma personagem coletiva ou um grupo de personagens e pode assumir funções actanciais diferentes.

Tendo como base todos os seus precursores, Greimas propõe um modelo universal, uma estrutura actancial que se reduz a seis funções: o sujeito (S) deseja um objeto $(\mathrm{O})$ - ser amado, ter dinheiro, honra, felicidade, poder ou qualquer outro valor - é ajudado por um adjuvante (A) e confrontado por um oponente (Op). O conjunto de feitos é desejado, orientado, arbitrado por um destinador (D1) em benefício de um destinatário (D2).

Quadro 5 - Modelo actancial de seis casas, conforme Greimas.

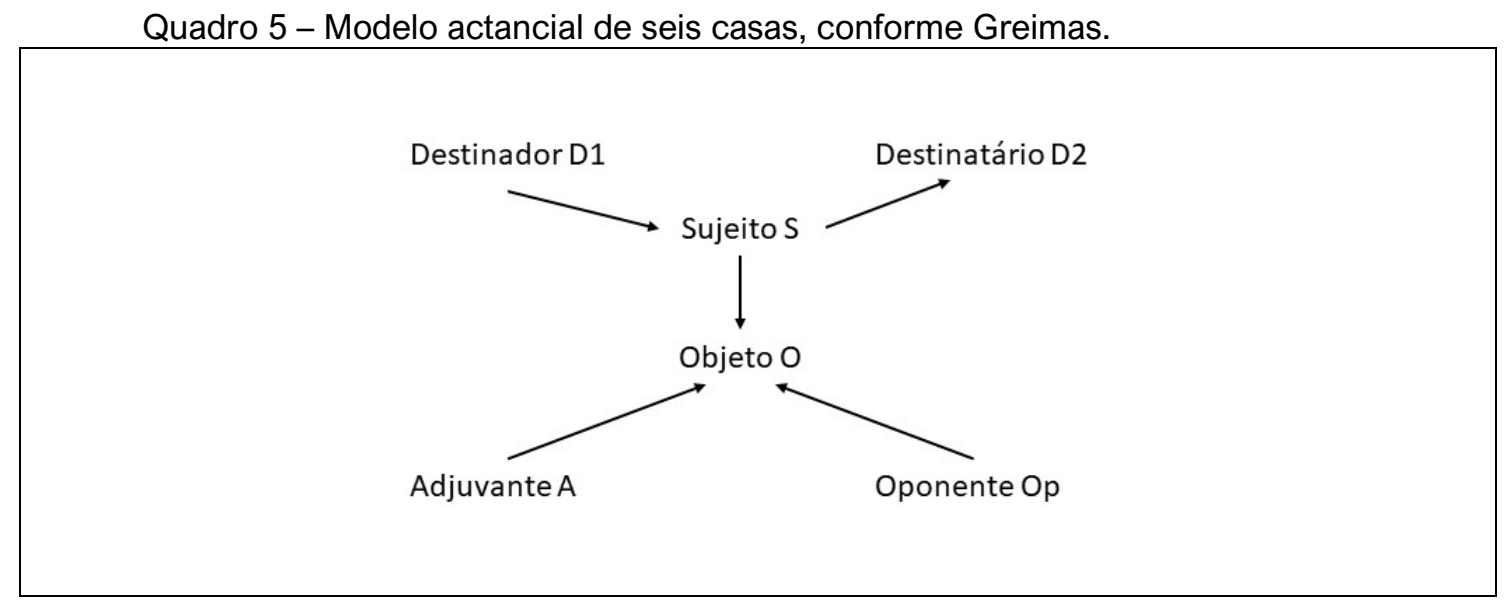

Fonte: UBERSFELD, 2013, p. 35.

70 Linguística: componente do sistema linguístico que determina as relações formais que interligam os constituintes da sentença, atribuindo-Ihe uma estrutura. (FERREIRA, 2010, p. 691) 
Os actantes se distribuem em pares posicionais, cuja flecha/vetor de forças pode funcionar nos dois sentidos, sendo que se manifesta geralmente pela contenda entre esses dois actantes.

Quadro 6 - Modelo actancial com separação entre os pares.

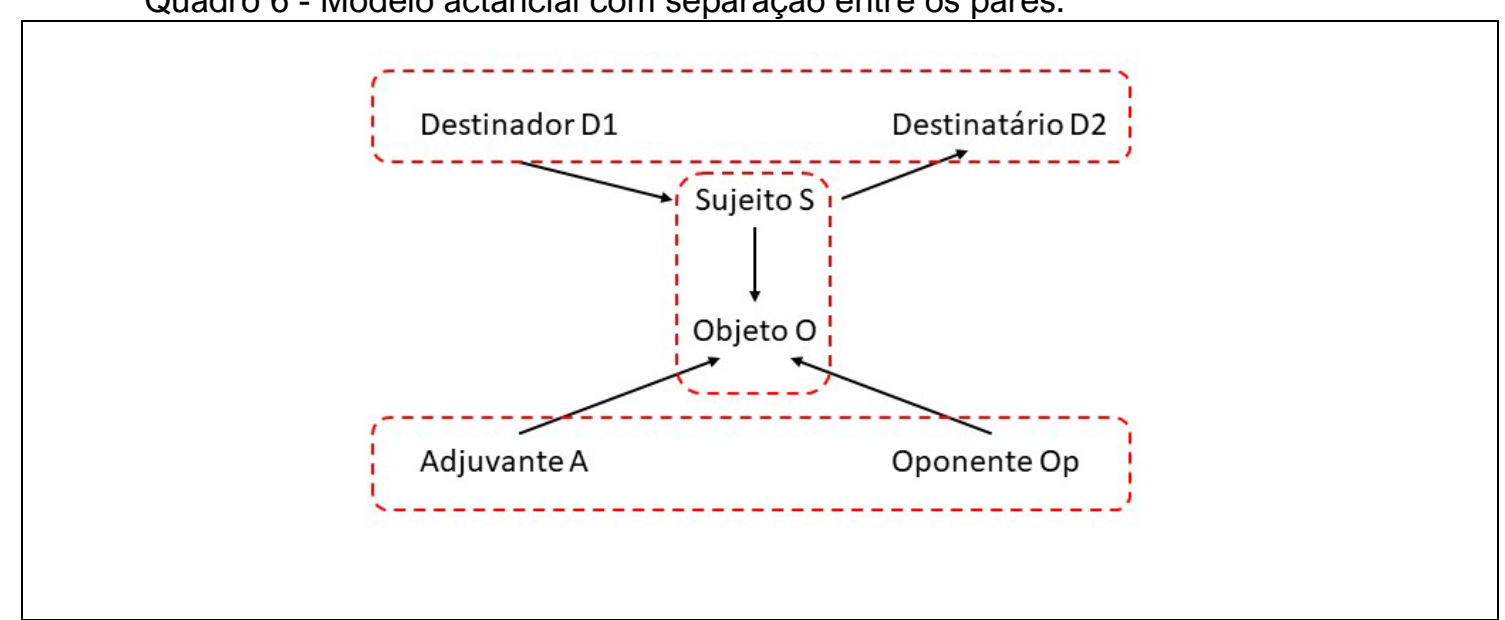

Fonte: UBERSFELD, 2013, p. 35

Ubersfeld ressalta que os actantes se distribuem em pares posicionais, conforme a figura 10 (sujeito/objeto, destinador/destinatário). O par adjuvante/oponente é um par oposicional cuja vetor pode funcionar nos dois sentidos e o conflito geralmente ocorre por colisão. Exponho agora resumidamente a relação entre cada par:

\section{Sujeitolobjeto}

É o par base da estrutura dramática. O sujeito ${ }^{71}$ converge suas forças em direção ao objeto ${ }^{72}$ do seu desejo (ser amado, dinheiro, honra, felicidade, poder ou qualquer outro valor).

Nesse ponto, Ubersfeld (2013, p. 42) faz uma colocação que considero bastante relevante: o sujeito não é o herói ou heroína do texto dramático, "a determinação de sujeito só pode dar-se em relação à ação, em sua correlação com o objeto", ou seja, o sujeito não é autônomo, só existe no eixo sujeito-objeto. "Um actante não é uma substância ou um ser, é um elemento de uma relação" $\left(2013\right.$, p.43) ${ }^{73}$. E essa relação precisa ser necessariamente ativa, no movimento ao objeto. Querer preservar não constitui o sujeito. Ele é o que age, o que se

\footnotetext{
${ }^{71}$ Podemos relacioná-lo também com o Leão, de Souriau.

72 Relacionável ao Sol.

${ }^{73}$ A ideia de relação é uma das questões estruturais na composição do drama e esse aspecto será a visto no quarto capítulo dessa dissertação.
} 
movimenta, o que se arroja. E é exatamente por isso, em Phèdre, que, ao quebrar o "estatuto" que exige o seu silêncio, a personagem homônima se torna sujeito.

\section{Adjuvante/oponente ${ }^{74}$}

Esse é o par que facilita ou impede a ação, além de produzir as circunstâncias e qualidade de sua prática. São os ajudantes e adversários. Muitas vezes não são encarnados em personagens, podendo inclusive ser subjetivos. No início, Phèdre é sua oponente, ou melhor dizendo, sua culpa opõe-se ao movimento em relação ao objeto. Quando ela confessa a Oenone, que se torna sua adjuvante, esse oponente se desloca. Tornando a ser intrínseco para a finalização trágica: o suicídio de Phèdre.

\section{Destinador/destinatário ${ }^{75}$}

Eis o par que exige o maior esforço intelectual na sua identificação, uma vez que não necessariamente se manifesta em personagem. Há uma dupla de perguntas diretas que auxiliam nesse reconhecimento:

- Quem ou o quê motiva o sujeito em relação ao seu desejo?

- A quem se destina o objeto desejado pelo sujeito?

Aqui se apresenta um elemento de controle dos valores e, portanto, da ideologia. É a motivação da ação do sujeito. Em Phèdre, o destinador é o amor que, dentro da estrutura específica da tragédia, podemos reconhecer em Vénus ${ }^{76}$.

Quanto ao destinatário, Phèdre quer o objeto (Hippolyte) para si ${ }^{77}$.

Anne Ubersfeld grafou em seu estudo a análise actancial de Phèdre, uma vez que identifica um caráter exemplar na constituição de suas ações: "se existe

\footnotetext{
${ }^{74}$ Podemos relacionar com Lua e Marte respectivamente.

${ }^{75}$ Podemos relacionar o destinatário com a Terra. Todavia não há correlação entre uma função dramatúrgica de Souriau e o destinador. Também, no modelo proposto por Greimas, a Balança ou árbitro desaparece.

${ }^{76}$ Apenas como esclarecimento: como estou me referindo à análise do texto original de Racine, a grafia do nome da deusa é apresentada tal como li.

${ }^{77}$ Essa é uma das características que distingue a tragédia ática da tragédia classicista. Os gregos tinham destinadores coletivos (retomar a paz e a ordem, retirar maldições, reconstituir o reino) enquanto no classicismo, os heróis e heroínas começam um movimento de destinador subjetivo (querer para si).
} 
um texto em que se lê o lugar triunfal, fulminante da heroína, é com certeza a Fedra, de Racine" (2013, p. 55). Vamos ao que ela propõe.

Phèdre como sujeito:

Quadro 7 - Modelo actancial com Phédre como sujeito

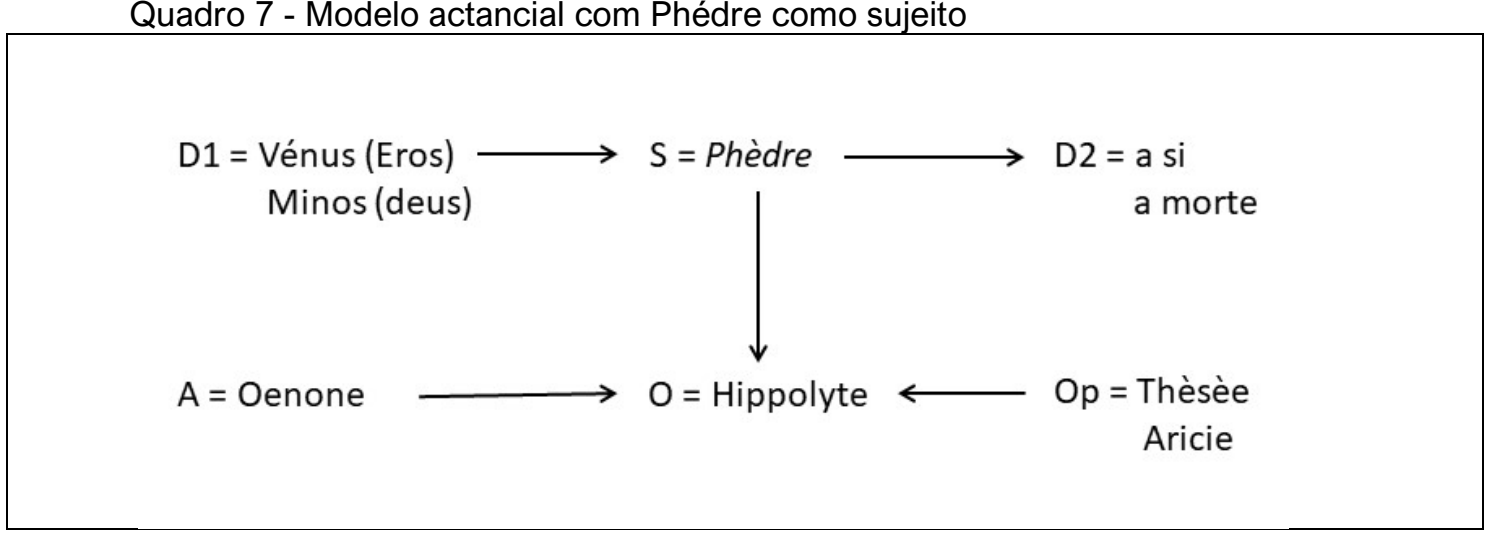

Fonte: UBERSFELD, 2013, p. 55

Hippolyte e Aricie como sujeitos:

Quadro 8 - Modelo actancial com Hippolyte e Aricie como sujeitos

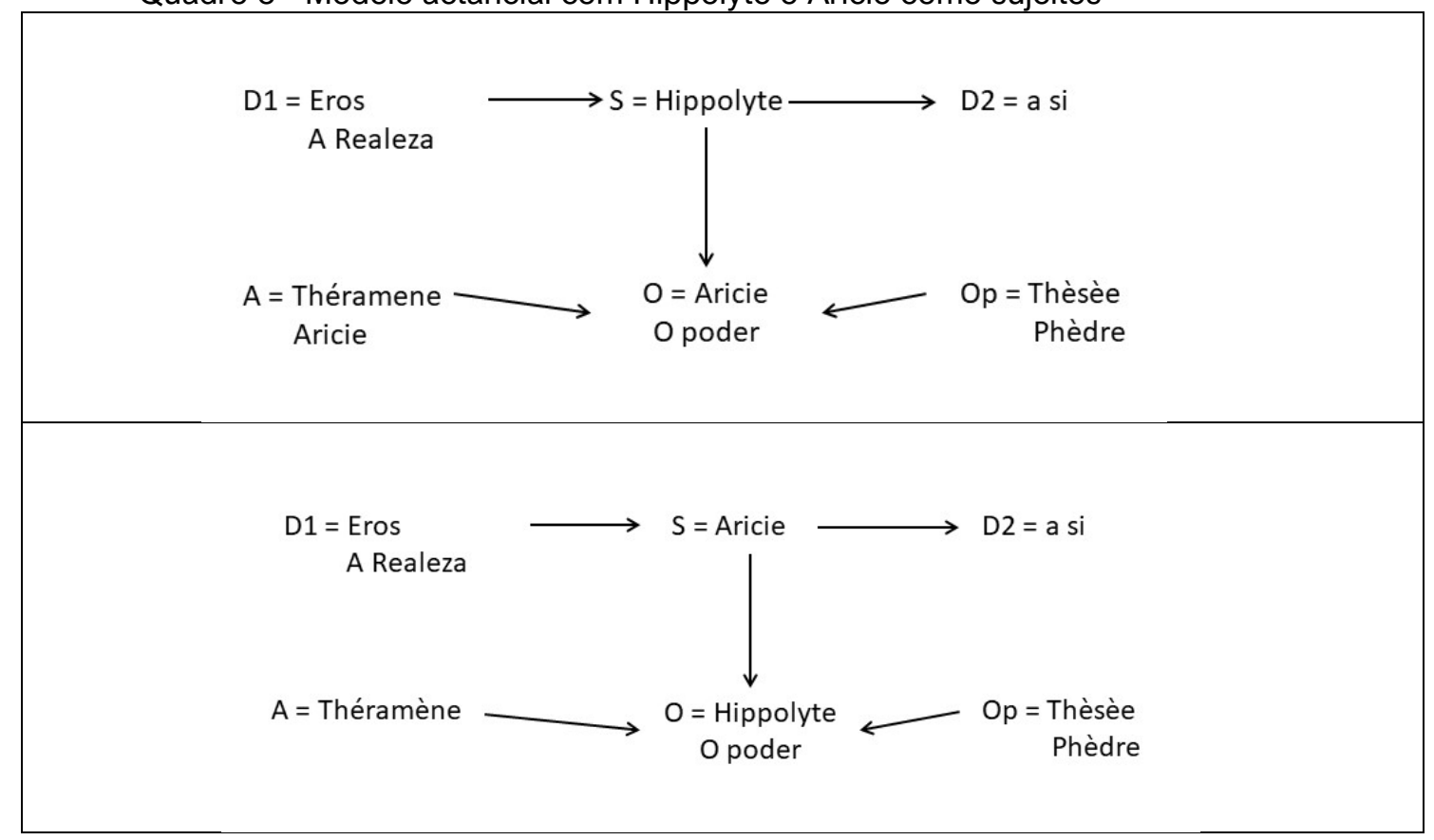

Fonte: UBERSFELD, 2013 p. 55

Partindo das análises teóricas de Phèdre de Racine, foram construídos jogos a fim de tecer a reescritura silenciosa da peça. 
Los ortodoxos de los cânones literários, los ortojodos de la palavra, no pueden compreender que hay una racionalidade poética que ordena el delírio de imágenes convocadas em turbión. Hay um tronco que organiza la locura de las ramas. Las ramas del árbol por el que canta um bosque ${ }^{78}$. (MARELLI, 2014, p. 113)

A progressão da pesquisa apresentada nesta dissertação, em quatro capítulos, não se deu de maneira sequencial e decupada. A prática se estruturou quase concomitante à teoria. No entanto, antes de iniciar o trabalho de composição da dramaturgia silenciosa a partir de Phèdre, precisei estabelecer um panorama com as teorias implicadas no trajeto e compartilhá-lo com o coletivo.

Outro dado é não ter iniciado a pesquisa no dia em que escrevi o projeto, nem no dia em que me matriculei no mestrado. Esse universo lateja em mim há muitos anos, e essa sucessão, que começa com a Poética, de Aristóteles, foi se somando a camadas de leituras e de práticas ao longo do tempo que decidi dedicar ao teatro.

Quando apresentei o projeto, ainda não era claro qual seria o texto base para o estudo do silêncio. Queria trabalhar com o dramático, porque acreditava na necessidade de uma composição normativa à guisa de lastro para que eu tivesse um meio de balizamento. Meu interesse consistia em reconhecer o potencial de compartilhamento da fábula por meio de uma dramaturgia sem palavras. No primeiro momento, pensei em trabalhar com um drama moderno, aventei vários autores, porém, logo no início, como que 'por acaso', deparei-me com a publicação do doutorado de Arnaud Rykner (2004). Em sua tese, ele expõe a função histórica do silêncio dentro do aparato funcional do diálogo dramático e

\footnotetext{
${ }^{78}$ Essa passagem cria um jogo entre as diferentes grafias "ortodoxos" e "ortojodos". Comentário de Letícia Soares, licenciada em Letras pela FFLCH e professora de espanhol, sobre a tradução: Ela me parece um exemplo do lunfardo característico da variedade rioplatense do espanhol. Uma espécie de gíria em que se trocam as sílabas das palavras. E, ao formar ortojodos, ou seja, ao trocar as sílabas, são formadas outras duas palavras: orto (vulgarismo muito usado que significa $\mathrm{cu}$ ) e jodo (de joder, que pode ter o sentido de fuder/ferrar, mas pode ter um sentido de encher o saco.) Então, esse jogo pode se relacionar aos "chatos da palavra". Por isso, essa epígrafe não terá tradução.
} 
sua potência comunicativa na elaboração cênica para além das palavras. Seu estudo abarca do classicismo até Maurice Maeterlinck ${ }^{79}$. Ao relatar sobre a dramaturgia classicista, ele evidencia a ausência do silêncio e, mais ainda, a convicção de dramaturgos e críticos do período de que não há possibilidades significativas sem a palavra. Como já disse no primeiro capítulo, D’Aubignac (1657, p. 339) é um dos que endossa essa ideia: "[...] o silêncio não deve ter parte no teatro, exceto nos intervalos entre os atos." ${ }^{80}$ Por tudo isso, o classicismo apresentou-se como ideal para este estudo, uma vez que sua posição era antitética à intensão desta investigação. Por tudo isso, quis estabelecer o processo de pesquisa com uma obra que fosse representativa do período. Nesse contexto, a dupla D'Aubignac/Racine se formou quase imediatamente. A indicação da obra veio por intermédio de Roland Barthes (2008, p. 143):

Dizer ou não dizer? Eis a questão. Aqui o próprio ser da fala é levado ao palco [...] pois o interesse trágico aí está muito menos no sentido da fala do que em seu aparecimento, muito menos no amor de Fedra do que em sua confissão [...] Desde o início Fedra se sabe culpada, e não é sua culpa que constitui problema, é seu silêncio.

A falha trágica de Phèdre é quebrar o silêncio em relação ao amor que ela sente por Hippolyte, então eu me vi ante a heroína perfeita para as minhas indagações.

Restava agora descobrir de que modo eu iria abordar Phèdre e, a partir dela, fazer nascer a Fedra. Seria preciso encontrar uma forma que promovesse a reflexão, a observação, mas também o respeito pela obra e pela heroína, algo que não se parecesse com uma dissecação, mas que proporcionasse partilha daquela Prèdre que emergiu em meio ao caldo cultural de uma monarquia absolutista do século XVII, para aportar neste momento histórico tumultuado em que nos encontramos no Brasil de 2018. Assim, nasceu a necessidade de que esta fosse uma reflexão prática e coletiva. Eu queria mais do que reconhecer o potencial comunicativo dos silêncios elípticos em Phèdre, eu precisava vê-los.

\subsection{Vistas para uma trajetória}

\footnotetext{
79 Maurice Maeterlinck (1862-1949), dramaturgo simbolista nascido na Bélgica, vencedor do Prêmio Nobel de Literatura em 1911. Seu teatro é reconhecido por ser precursor na exploração estética do silêncio. (MOLER, 2006)

80 "[...] le silence ne doit point avoir au theatre, que dans les intervales des actes." (tradução minha)
} 
Dado o caráter da pesquisa, a primeira parte do processo, portanto, seria a constituição do coletivo, cujos participantes precisariam de experiência teatral, sem a necessidade de concentração em uma área específica (dramaturgia, direção, interpretação, cenografia, etc), e que fosse significativa o suficiente para permitir a investigação colaborativa do silêncio. Contatei pessoas que participam dos coletivos com os quais trabalho ou trabalhei, e formou-se o seguinte grupo:

- ADRIANA AZENHA - atriz, arte-educadora, dramaturga e diretora de teatro, com formação em ballet clássico.

- DANI ALBA - ator, diretor, dramaturgo e músico, com experiência em teatro em escolas na Itália, Argentina e Brasil (São Paulo e Maranhão).

- EDUARDO ALEIXO - dramaturgo, formado pela Escola Livre de Teatro de Santo André e SP Escola de Teatro. Vencedor do Concurso SESC Jovens Dramaturgos 2015 e Menção Honrosa no Programa Nascente da Universidade de São Paulo.

- EDUARDO BARTOLOMEU - ator, diretor, educador e dramaturgo, participa do Coletivo GRÃO e do Grupo Teatro Vento Forte. Integrou a primeira formação do Corpo Estável de Teatro de Jundiaí.

- JANY CANELA - atriz com mais de dez anos de experiência e participação em turnês internacionais com a Cia Pau D'Arco de Teatro.

- LETICIA SOARES - atriz formada pelo INDAC, pós-graduada em Arte na Educação pela ECA/USP, graduada em Letras pela Universidade de São Paulo, em Português e Espanhol.

- MARCO ALBUQUERQUE - ator, diretor e dramaturgo, participou da edição de 2011/2012, do Núcleo de Dramaturgia Sesi British Council, com Marici Salomão.

- MIRIAM LIMA - atriz, cantora e roteirista, graduada em Letras pela Universidade de São Paulo, em Português e Inglês.

- ROGÉRIO FAVORETTO - ator, diretor e dramaturgo, pós-graduado em Artes Cênicas pela Universidade São Judas Tadeu.

- VICTOR DE SEIXAS - mímico, doutorando em Pedagogia do Teatro pela USP, estudou na International School of Corporeal Mime (UK), 
School of Physical Theatre (UK), Dance Research Studio (UK), coordenou o Projeto Mímicas, organizando a Mostra de Mímica Contemporânea na cidade de São Paulo (2009-2013).

\subsubsection{Jogo}

Ainda adolescente, quando participava de grupos amadores de teatro, 0 jogo fazia parte do meu universo. A primeira vez que li sobre o tema, foi com o "empréstimo" de um livro retirado da estante de uma das minhas irmãs, sem que ele soubesse: 200 exercícios e jogos para o ator e o não ator com vontade de dizer algo através do teatro, de Augusto Boal (1999) ${ }^{81}$. Gostava, sobretudo, de reproduzir as posturas corporais e as caretas que via nas fotos. Quando entrei na graduação em Artes Cênicas, passei a me dedicar, sistematicamente, aos jogos e à improvisação durante as aulas, com as Professoras Doutoras Maria Lúcia Puppo e Ingrid Dormien Koudela, e com o Professor Doutor Antônio Januzelli, o Janô. Concomitante a isso, participei das formações de jogo, máscara e palhaço com a Professora Mestra Cristiane Vieira, a Quito. Segui o meu trajeto operando desta forma, por considerar o jogo teatral elemento estrutural na formação de um ambiente criativo, tanto porque é capaz de promover relações colaborativas como porque conduz o jogador a se colocar de forma espontânea.

Segundo Johan Huizinga (2000, p. 24),

O jogo é uma atividade ou ocupação voluntária, exercida dentro de certos e determinados limites de tempo e de espaço, segundo regras livremente consentidas, mas absolutamente obrigatórias, dotado de um fim em si mesmo, acompanhado de um sentimento de tensão e de alegria e de uma consciência de ser diferente da "vida quotidiana".

Huizinga também aborda o aspecto ficcional do jogo, o "faz de conta", constituindo um ambiente de simulação e representação. Visto dessa forma, o jogo confunde-se com o próprio teatro.

As orientações estabelecidas por Viola Spolin forneceram, ao longo dos anos em que trabalho com teatro, os fundamentos práticos para articular jogos teatrais como esteio no processo criativo de atores e atrizes tanto em contextos

\footnotetext{
${ }^{81}$ O livro que consta da bibliografia é uma edição revista cujo nome é Jogos para atores e não
} atores. 
individuais de percepção de tempo, espaço, ritmo, etc., quanto para o estabelecimento de relações com o grupo e no trabalho com texto. Por tudo isso, suas sessões práticas serviram de azimute no processo de pesquisa. Em seu livro Improvisação para o Teatro (2015) postula sete aspectos da espontaneidade experimentadas no jogo, que resumirei aqui:

1. O jogo é uma forma natural de convivência de grupo e um ambiente propício para o desenvolvimento de habilidades, uma vez que não há necessidades prévias, jogar habilita o jogador durante o processo;

2. É favorável à espontaneidade, uma vez que, na solução de um problema, sendo observadas as regras, qualquer caminho deve/pode ser experimentado;

3. É útil para a compreensão das convenções, tanto no teatro formal como no desenvolvimento da habilidade de improvisar;

4. Qualquer jogo é altamente social e pressupõe soluções coletivas;

5. A pessoa é "[...] despertada física, intelectual e intuitivamente" (SPOLIN, 2015, p. 4);

6. "[...] Todas as partes do indivíduo funcionam juntas como uma unidade de trabalho" (SPOLIN, 2015, p. 5), ou seja, a participação é de um "indivíduo total";

7. Tendo como arbítrio externo apenas as regras do jogo, toda a energia é concentrada em resolver o problema e não em agradar ou desagradar alguém.

Com isso, na constituição do ambiente criativo, e na relação com Phèdre, o jogo tornou-se importante procedimento metodológico na relação texto-cena.

\subsubsection{Pedagogia da Cooperação}

Junto com as sessões de jogos orientadas a partir do estudo de Viola Spolin, entre 2010 e 2011, participei de um processo de aprendizagem absolutamente impactante na minha forma de olhar o jogo teatral: foi o momento em que cursei uma pós-graduação latu sensu em jogos cooperativos, uma iniciativa de profissionais e pesquisadores de diferentes áreas, ligados à Cultura 
de Paz, e reunidos em torno do Projeto Cooperação ${ }^{82}$.

O jogo cooperativo tem como objetivos, execução e resultados coletivos. Suas características fundamentais são:

- Não há eliminação de jogadores durante o jogo;

- Não há solução única, a estratégia é traçada ao longo do jogo;

- Não há distinção pela performance;

- O jogo é totalmente inclusivo.

Por mais que o jogo teatral, naturalmente, crie um ambiente de espontaneidade para a participação e, potencialmente, garanta as características relacionadas acima, em função de o objetivo ser a reescritura a partir de um texto matriz, havia o risco de que se estabelecessem estruturas hierárquicas intrínsecas ao teatro, como a definição de personagens (protagonista, antagonista, adjuvante, por exemplo) e o estabelecimento de papéis (direção, interpretação, cenografia, etc.). Na persona pesquisador era essencial que todos e todas colaborassem igualmente em todas as áreas, porque o foco estava em descobrir o modo de fazer e não no resultado.

No segundo capítulo desta dissertação, fiz uma rápida progressão - dando saltos olímpicos - entre a figura do poeta dramático na França do século XVII e a multiplicidade da dramaturgia contemporânea. Retomo agora essa temática, justamente porque lá anunciei os criadores cênicos e criadoras cênicas, que passarei a chamar de CRIAS, e é aqui que essa persona será explicitada.

A ideia dos e das CRIAS era a não fixação de papéis, porque a leitura seria dada pela experiência e não pela performance, daí o câmbio. Essa convenção foi baseada em um tipo de jogo cooperativo que é o de resultado coletivo, no qual o que importa não é a posição que cada um ocupe, mas a conquista do grupo ${ }^{83}$. Dessa forma, CRIAS operavam em sistema de câmbio permanente. Não havia a

82 Empresa formada por profissionais que desenvolvem atividades e divulgam projetos de cooperação. O início aconteceu com os educadores físicos Gisela Sartori Franco e Fábio Otuzi Brotto em clínicas de jogos cooperativos realizadas na Escola de Educação Física e Esporte da USP (EEFEUSP) no ano de 1995.

${ }^{83} \mathrm{Um}$ exemplo é o jogo Bater e fugir depressa. começa com dois times com o mesmo número de jogadores cada um, em lados diferentes de uma rede de voleibol. Sempre que um jogador bate na bola para arremessá-la sobre a rede, passa correndo por debaixo da rede para o outro lado. Os jogadores tentam fazer uma alteração completa dos times com o mínimo possível de quedas de bola. (ORLICK, 1993, p. 126) 
fixação para a interpretação das personagens da peça nem dos papéis criativos para cada um: ora um ou uma CRIA interpretava, ora desenhava um roteiro ou escrevia uma didascália.

O jogo cooperativo, no entanto, é um dos processos de uma unidade maior, que é a Pedagogia da Cooperação, que pode ser definida como "[...] conjunto de conhecimentos e práticas orientado para a promoção da Cultura da Cooperação e o desenvolvimento de Comum-Unidades ${ }^{84}$ Cooperativas em diferentes ambientes." (BROTTO, 2018, p. 1) e que se vale de princípios, processos, procedimentos e práticas para a obtenção do propósito, os chamados

\section{5 pês.}

Aqui resumo os princípios, a partir da enunciação de Brotto:

- Co-existência - conscientização da interdependência;

- Com-vivência - reconhecimento das identidades individuais e desenvolvimento do olhar apreciativo sobre as diferenças;

- Cooperação - "exercício de corresponsabilidade para o aprimoramento das relações humanas" (BROTTO, 2018, p. 15)

- Com-unidade - resultante da trama entre os três outros princípios e a constituição de um espírito de corpo.

A Pedagogia da Cooperação se serve de procedimentos específicos e de sete práticas que objetivam a constituição de um ambiente no qual todos se sintam atuantes e integrados (vide Quadro 1, abaixo). As práticas e procedimentos aqui descritos têm registro nos Cadernos de Referência do Esporte, da Fundação Vale (2013), e na Pedagogia da Cooperação (no prelo) do Professor Me. Fábio Brotto (2018).

Tendo isso em mente, a Pedagogia da Cooperação foi aplicada como eixo de articulação dos jogos teatrais ao longo da pesquisa. Suas práticas e procedimentos foram observadas tanto dentro da estrutura macro do projeto, pensando no objetivo da pesquisa que era a constituição do estudo do silêncio em Phédre, como na estrutura micro de cada sessão, no planejamento de cada encontro para estudo. O centro nervoso da Pedagogia da cooperação é a

${ }^{84}$ Essa divisão de palavras e a grafia são adotadas por Fábio Brotto para as acepções da cooperação. 
compreensão da corresponsabilidade coletiva e da potencialização das

habilidades individuais. Quanto maior for a diversidade do grupo, maior a sua abundância na busca por respostas.

Farei a exposição das práticas e procedimentos na relação com os processos, em uma tentativa de que a narrativa recomponha a aplicação.

Quadro 9 - Sete práticas da pedagogia da cooperação

\begin{tabular}{|c|c|}
\hline Prática & Objetivo \\
\hline $\begin{array}{l}\text { 1a) Fazer COM-TATO } \\
\text { Saber conectar }\end{array}$ & $\begin{array}{l}\text { Promover o contato, aproximação e } \\
\text { integração. Reunir a turma para começar } \\
\text { unida o processo. Ser um ponto de partida } \\
\text { acolhedor, atraente e que desperte a } \\
\text { curiosidade e a vontade de continuar jogando } \\
\text { junto. }\end{array}$ \\
\hline $\begin{array}{l}\left.2^{a}\right) \text { Estabelecer COM-TRATO } \\
\text { Saber cuidar }\end{array}$ & $\begin{array}{l}\text { Estabelecer acordos de cooperação e de } \\
\text { com-vivência, para que cada pessoa (e todo } \\
\text { grupo) tenha conhecimento dos cuidados } \\
\text { necessários para promover e sustentar uma } \\
\text { sensação de bem-estar pessoal e coletivo. }\end{array}$ \\
\hline $\begin{array}{l}3^{\text {a }) ~ C o m p a r t i l h a r ~ I N-Q U I E T A-A C ̧ O ̃ E S ~} \\
\text { Saber compartilhar }\end{array}$ & $\begin{array}{l}\text { Compartilhar perguntas, dúvidas, } \\
\text { inquietações e incertezas sobre o tema/foco } \\
\text { do encontro. }\end{array}$ \\
\hline $\begin{array}{l}\left.4^{a}\right) \text { Fortalecer alianças e parcerias } \\
\text { Saber confiar }\end{array}$ & $\begin{array}{l}\text { Exercitar as competências para regenerar } \\
\text { e/ou fortalecer as relações de parceria e } \\
\text { cooperação no grupo. } \\
\text { Habilidades de relacionamento: autonomia, } \\
\text { respeito mútuo, confiança, empatia, } \\
\text { inclusividade, etc. } \\
\text { Habilidades de rendimento: proatividade, } \\
\text { resiliência, criatividade, organização, etc. }\end{array}$ \\
\hline $\begin{array}{l}5^{\text {a) }} \text { Reunir soluções COMO-UNS } \\
\text { Saber co-criar }\end{array}$ & $\begin{array}{l}\text { Fazer a colheita de todas as ideias, sugestões, } \\
\text { dicas, comentários, insights e respostas } \\
\text { produzidas na } 3^{\mathrm{a}} \text { prática (in-quieta-ações). }\end{array}$ \\
\hline 6ª) Realizar projetos de cooperação & $\begin{array}{l}\text { Transferir, para o dia-a-dia, a realização das } \\
\text { soluções COMO-UNS, por meio da prática } \\
\text { pessoal e coletiva de pequenas, simples e } \\
\text { poderosas estratégias. }\end{array}$ \\
\hline 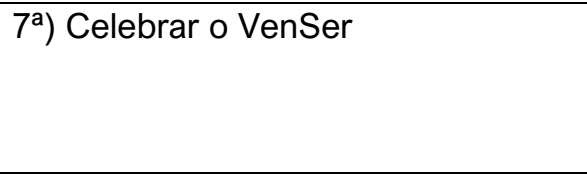 & $\begin{array}{l}\text { Rever toda a experiência, reconhecendo as } \\
\text { aprendizagens pessoais e coletivas. } \\
\text { Celebrar o exercício do VenSer quem se é } \\
\text { para poder SerVir melhor ao mundo. }\end{array}$ \\
\hline
\end{tabular}

Fonte: BROTTO,F. Pedagocia da Cooperação [no prelo], 2018, p. 28-34 
4.2 Um processo de trabalho

Passo agora ao relato do processo de trabalho que estabelecemos ao longo das sessões de pesquisa da constituição da dramaturgia do silêncio de Phèdre para Fedra.

\subsubsection{Primeira prática - Fazer COM-TATO (vide Quadro 9)}

O primeiro contato com grupo é um "quebra-gelo", uma maneira de reunir as pessoas em torno do objetivo comum. É importante estabelecer essa prática antes de cada sessão e não somente para dar início à pesquisa, porque é uma forma de identificar as necessidades individuais e as do grupo. É muito importante reconhecer as pessoas antes de começar o trabalho, para que o processo não seja frio e mecânico. Este primeiro momento pode se dar por meio de uma pergunta simples, 'como você está hoje?', por exemplo e, a partir da qual, observa-se se que planejamento de trabalho com o grupo deverá ser mantido.

Em nossas sessões diárias, havia sempre alguma referência ao trânsito ou ao metrô. Uma vez que os incômodos eram relatados, aos poucos, iam se dissipando. Também houve relatos de tristeza e apreensão ${ }^{85}$.

Os diálogos sempre acontecem com o procedimento ' $\mathrm{O}$ círculo e $\mathrm{O}$ centro', da Pedagogia da Cooperação (vide Quadro 10).

Quadro 10 - Procedimento: o círculo e o centro

\begin{tabular}{|l|}
\hline \multicolumn{1}{|c|}{ Procedimento: o círculo e o centro } \\
\hline Sempre que o coletivo se reúne para refletir, deliberar, construir acordos, ou seja, sempre que \\
há uma necessidade dialógica sobre o processo, essa organização acontece com todos os \\
participantes sentados em círculo em torno de um centro. O centro, por sua vez, é concreto, \\
constituído de algo que seja significativo para o grupo.
\end{tabular}

Fonte: FUNDAÇÃO VALE, 2013, p. 32

Minha proposta para o primeiro COM-TATO entre as pessoas, no início dos trabalhos, também foi uma oportunidade de apresentação da pesquisa e seus objetivos. Nesse momento, estabeleci a seguinte sequência preliminar:

${ }^{85} \mathrm{Em}$ um dia, em que estavam apenas as mulheres do grupo, um desses relatos tinha uma carga emocional tão forte que nos obrigou a transformar o encontro em uma sessão de diálogos coletivos. Procurei ficar sempre sensível ao coletivo. Fiz câmbios de trabalho em função de acontecimentos. 
Apresentação geral do projeto:

- Apresentação do histórico que deu origem à pesquisa;

- Diálogo sobre o processo de construção coletiva.

Abertura para apresentação individual ${ }^{86}$ :

- Quem é você?

- Como veio até aqui?

- Quais são suas expectativas com relação a essa pesquisa?

Sessão de jogos de apresentação:

- Jogos de simples assimilação, mas que servem para que se escutem os nomes várias vezes, e para um primeiro quebra-gelo;

Sessão de jogos tradicionais:

- Forma de estabelecer um clima de diversão, mas também preparar-se para os jogos teatrais.

Jogos teatrais:

- Simples e lúdicos, como introdução e não parte significativa do processo criativo. $\mathrm{O}$ objetivo era criar um ambiente de jogo e não propriamente desenvolver algum enredo específico.

Como alguns CRIAS se conheciam e outros não, esses movimentos iniciais foram importantes para que, aos poucos, as pessoas se identificassem.

Durante os encontros com CRIAS, dentro da perspectiva desta pesquisa, considerei muito importante esclarecer que a proposta de construção coletiva não era retórica, mas que o processo seria desenvolvido com olhar apreciativo sobre a contribuição de cada indivíduo. De acordo com os princípios da Pedagogia da Cooperação, a diversidade traz abundância e promove um maior espectro de possibilidades na resolução de problemas, ao longo do desenvolvimento do projeto. A ideia é propor um ambiente de encontro entre todos, suas características, suas potências e proposições.

Os jogos de quebra-gelo ${ }^{87}$ fazem parte dos exercícios de aquecimento

${ }^{86}$ Quando os CRIAS e as CRIAS se apresentaram e disseram o seu propósito, todos estavam concentrados, não houve quebra de ritmo, e todos demonstraram interesse legítimo e compreensão dos valores incutidos na pesquisa.

${ }^{87}$ Como referência de jogo de quebra-gelo, os CRIAS e as CRIAS caminham pelo espaço da sala e, a cada vez que cruzam com alguém, dão um abraço, aleatoriamente. Nesse processo, é necessária a ocupação dos espaços da sala de maneira uniforme, sem "buracos". Em seguida, 
diário, e isto tem dois objetivos prioritários: a criação de experiências lúdicas de contato e solução de pequenos problemas, e o reconhecimento de ações físicas com produção de significado.

\subsubsection{Segunda prática - Estabelecer COM-TRATO (vide Quadro 9)}

Os Com-tratos (vide Quadro 9) são fundamentais na constituição de um coletivo harmônico, por isso devem ser explícitos, podendo-se, para tanto, usar uma folha de papel onde todos escrevam as suas necessidades. Certas questões são passíveis de negociação, enquanto outras, no entanto, podem ser intransponíveis. Nada pode ser tácito e nada é imutável. O que foi negociado pode ser renegociado, em função dos acontecimentos.

A CRIA Letícia iniciou o processo no quarto mês de gravidez. Era evidente que sua presença exigia uma qualidade especial de atenção, por isso foram enumeradas, em com-trato, quais seriam as condições de sua participação. $O$ objetivo era acolher, desde que sem a perda de foco.

Há condições tão díspares em relação ao objetivo de um grupo que pode chegar a inviabilizar o processo. Na minha experiência, as maiores discussões giram em torno dos horários (entrada, saída e intervalo) e alguns cuidados de higiene e saúde (água, banheiros, comida) ${ }^{88}$.

Como estratégia para a criação do ambiente de jogo, elaboro a construção de um rito inicial. O objetivo desse rito é funcionar como a criação de uma espécie de portal que cada CRIA tenha que transpor para iniciar o processo de vínculo. A ideia é que, nesta 'passagem', as questões externas (trânsito, preocupações de trabalho, família, etc.) sejam dissipadas aos poucos e não contaminem o ambiente criativo de jogo que se pretende instituir. Segundo

desenham-se linhas no chão, para que se caminhe apenas nelas, e, aos poucos, são propostos obstáculos (como não pisar na linha de cor diferente daquela na qual está caminhando, e quando cruzar alguém, pensar neste corpo não como obstáculo, mas como um suporte para a continuidade da caminhada). Esses jogos podem servir apenas como aquecimento, mas também podem ser usados no início de desenho de cena.

${ }^{88}$ Numa sessão, na USP, houve uma invasão de baratas. Entrei na sala e vi uma barata. Dispusme a matá-la. Logo vi outra e outra, até que percebi que havia uma "multidão de baratas" saindo do esgoto próximo à sala. Esperei a chegada dos CRIAS e das CRIAS e fizemos o acordo de que, naquele dia, faríamos uma reflexão teórica sobre Phèdre na lanchonete. 
Ryngaert (2009, p. 40) "[...] um rito é, no sentido figurado, uma prática regrada, invariável, uma maneira habitual de fazer."

Figura 6 - Tapete de crochê e Carta dos Anjos para compor o centro do círculo.

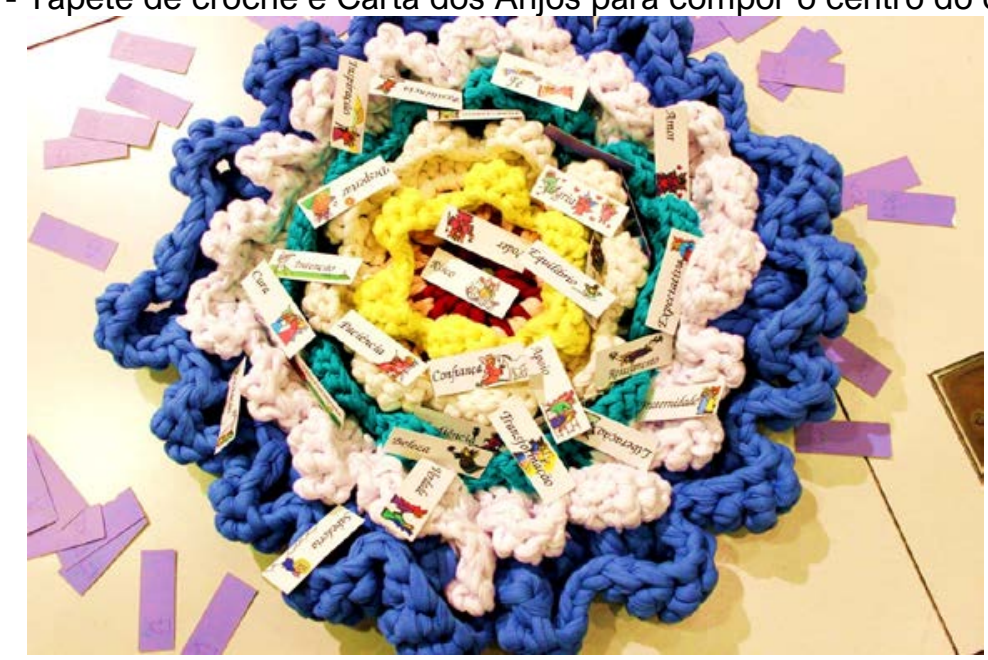

Fonte: fotografia do processo de pesquisa. Autoria: Geraldo Lima

- O rito de início do ensaio começa impreterivelmente no horário marcado no com-trato;

- A abertura é sempre com uma mesma atividade ${ }^{89}$;

- Na sequência, estabelece-se uma roda de diálogo que repassa, de forma rápida, os acontecimentos individuais ${ }^{90}$, mas que, sobretudo, resgata o que foi vivido no encontro anterior do coletivo;

- Após esta roda, todos retiram a Carta dos Anjos (TYLER \& DRAKE, 2011) ${ }^{91}$, que é um conjunto de pequenas cartas com palavras aleatórias: amor, perdão, disponibilidade, concentração, etc. (vide Figura 12). As conexões são estabelecidas subjetivamente e não precisam ser partilhadas. É apenas uma ferramenta de orientação

${ }^{89}$ Sempre começávamos com a dança circular Highland Hilt, de origem celta e de tradição oral, cujos passos são invariáveis e de simples assimilação.

90 Este momento é importante para um primeiro balizamento da energia do grupo. Às vezes, nesta roda, descobrem-se acontecimentos individuais que podem influenciar de forma marcante o andamento do coletivo. Essa consciência ajuda a organizar o encontro e estruturar mudanças de planejamento, caso necessário.

91 O Livro da Carta dos Anjos propõe uma série de 72 cartas, cada uma com uma palavra diferente, cujo significado, no livro que as acompanha, é expandido. Por exemplo: "[...] Liberdade - você está livre para mudar a sua experiência, mudando os critérios nos quais se baseia para tomar decisões. Livre-se das velhas armadilhas e expresse sua singularidade." (TYLER \& DRAKE, 2011, p. 52) 
para um ponto de concentração ${ }^{92}$.

Os jogos de aquecimento começam após estabelecer-se desse ambiente, que não tem um caráter místico, é antes a construção de estruturas que coloquem a atenção dentro da sala de ensaio. O rito pode acontecer de inúmeras maneiras: com uma respiração coletiva de mãos dadas, com aquecimentos individuais feitos em silêncio, por exemplo. Não importa a atividade apenas a sua constância, simplicidade e encadeamento, sempre começando com uma atividade de fácil execução e possível para todos.

\subsubsection{Terceira prática - Compartilhar IN-QUIETA-AÇÕES (vide Quadro 9)}

O alinhamento do coletivo com relação à busca da pesquisa é essencial e isto não deve acontecer apenas no aspecto macro, mas é necessário para as pequenas percepções. Tanto a cena como as relações interpessoais são construídas pelas sutilezas. Também é bem importante que as possíveis respostas às perguntas partam de percepções do coletivo e não sejam impostas por alguma realidade externa.

Quadro 11 - Procedimento: ensinagem cooperativa

\begin{tabular}{|l|}
\hline \multicolumn{1}{|c|}{ Procedimento - Ensinagem ${ }^{93}$ Cooperativa } \\
\hline Esse procedimento consiste no ensino-aprendizagem em cooperação. Ele se vale de quatro \\
elementos: \\
- Convivência: a vivência da prática compartilhada e abertura para a experimentação \\
consigo mesmo e com os outros; \\
- Consciência: a percepção da própria prática, reflexão do "eu" diante do coletivo; \\
- Compartilhar Essência: o diálogo, a troca das percepçães individuais com o coletivo. \\
- Transcendência: a disposição para experimentar possibilidades de mudança em \\
função do convívio coletivo. No modo de ver, de agir e de pensar.
\end{tabular}

Fonte: FUNDAÇÃO VALE, 2013, p. 32

\footnotetext{
92 Viola Spolin (2015) observa que o ponto de concentração ou "foco" é a atenção dirigida para algo, alguém ou algum acontecimento dentro da realidade do palco o que cria uma "âncora (o estático) que torna o movimento possível" (parêntesis da autora). Assim as cartas viram um ponto de observação para que cada CRIA se concentre em lugar de se ocupar com o seu desempenho na cena.

93 "Ensinagem" representa a síntese entre o ensino e a aprendizagem, em que um co-existe com o outro. Esse termo foi criado pela Professora Dra. Neyde Marques, da UFBA e do Centro de Desenvolvimento Humano. (BROTTO, 2018, p. 14)
} 
Logo de início, o alinhamento estava em torno de uma pergunta essencial: O que é o silêncio?

Em 1950, o pianista David Tudor interpreta, pela primeira vez, a obra 4'33", de John Cage. Há um vídeo no Youtube (CAGE, 1952), no qual ele reproduz essa performance. Irei descrevê-la: Tudor se senta ao piano, organiza a partitura no suporte e, então, retira um pequeno cronômetro, daqueles redondos analógicos, que já estava posicionado próximo à partitura. Aperta o botão do cronômetro para zerá-lo, afasta um pouco a partitura para que ela não cubra a tampa do teclado, dispara o cronômetro e fecha a tampa. Coloca as mãos sobre as coxas e olha o cronômetro. Coloca-o sobre a tampa fechada do piano. Observa o cronômetro por alguns minutos, retira o relógio de cima da tampa, abre, torna a fechar a tampa. Recoloca o relógio sobre ela. Isso se repete por três vezes, em três movimentos de duração irregular. Nenhum som é produzido por intermédio das teclas do piano.

Há, no entanto, há uma profusão de outros sons, alguns muito sutis, como o pequeno atrito da tampa com o piano, o mexer das partituras, a respiração de David Tudor. São resultantes do músico performer. Mas há outros inúmeros sons que se somam a esses, produzidos pelos espectadores: tosses, ranger das cadeiras, cochichos, desenrolar de papéis de bala, entre outros mais ou menos evidentes e decodificáveis. O silêncio aqui, como ausência de som, não se observa. Não existe a produção intencional em meio aos signos que o indicam: o músico se senta ao piano, logo, espera-se que ele vá produzir uma sequência de notas organizadas de maneira tal que possam ser nominadas música. Este seria o som relativo a esta performance. No entanto, a música é produzida; uma música espontânea que nasce desta performatividade ${ }^{94}$ com o silêncio, que, no caso, é o não tocar. John Cage extrai o meio (tocar o piano), mas mantém a estrutura (música).

Essa ideia é retomada pela Professora Doutora Eleonora Fabião (2011), ao fazer uma reflexão sobre a obra de Lígia Clark, artista que liga a performance ao

\footnotetext{
${ }^{94} \mathrm{O}$ conceito de performance é bastante aberto. No dicionário de Pavis (2015, p. 284), o primeiro sentido empregado é de "teatro das artes visuais". A ideia geral é de uma realização artística alusiva à presença física do artista em relação a objetos e ao espaço.
} 
precário. Lígia, em sua "migração" da realização de obras de arte com a finalidade de exibição para obras com fim terapêutico, reconhece que a substância do seu trabalho está no reconhecimento do precário como gerador de mobilidade e não na busca da "unidade total" da obra, ou seja, aquilo que falta coloca o espectador como participante para a geração do sentido, conforme coloca Fabião (2011, p. 65):

Performers são poetas que investigam, criam e disseminam precários: a precariedade do sentido (que deixa de ser pré-estabelecido e fixado para ser condicional, mutante, performativo), a precariedade do capital (cuja supremacia é desbancada e a pobreza exposta), a precariedade do corpo (que, longe de ser percebida como deficiência, é atualizada como potência) e a precariedade da arte (que se volta para o ato e para o corpo).

Essa foi a base da nossa conceituação do silêncio: a extirpação da palavra escrita e sua tradução pelas ações do corpo. Não pela pantomina ${ }^{95}$, que estabelece uma comunicação simbólica, mas por um processo no qual a comunicação é paradigmática, acontecendo na relação entre as coisas: a intrarelação do ator ou atriz com o próprio corpo, a relação entre os corpos dos atores e/ou atrizes, a relação entre os corpos e os objetos e a relação entre as imagens e o espectador. Aqui, diferentemente da performance, o sentido não é absolutamente precário, uma vez que o norteador é a fábula de Phèdre.

Para o processo, era muito importante que essa compreensão de sentido não fosse algo racional, mas que "penetrasse" diretamente no corpo do coletivo. Para tanto, houve uma progressão de encontros, a fim de encontrarmos essa unidade e reconhecer as individualidades ${ }^{96}$.

\subsubsection{Quarta prática - Fortalecer alianças e parcerias (vide Quadro 9)}

A pesquisa da "Dramaturgia do Silêncio" está ancorada em uma tríade: o

\footnotetext{
${ }^{95}$ Pantomima na acepção referida no segundo capítulo.

${ }^{96} \mathrm{O}$ CRIA Mariana é surda e se comunica apenas pela sua língua natural, que é a Língua Brasileira de Sinais. Dentro do coletivo, eu e Letícia, irmã de Mariana, usávamos a língua falada (?). A presença de Mariana estabeleceu um tipo de convivência mais silenciosa, uma vez que a partilha das subjetividades observadas ao longo dos jogos só seria possível com tradução, o que tornava o processo um tanto cansativo. Muitas vezes, a partilha foi feita em silêncio, pela troca de olhares e alguns gestos com uma significação muito evidente. Esse exercício cotidiano, aos poucos, foi sendo deslocado para a cena.
} 
corpo do ator, o texto e o espaço, entendendo-se esses elementos com a sua relevância enquanto signos e que, neste contexto, só são possíveis em relação um com o outro e com os outros, que vem a ser os espectadores. A fim de fechar todos os lados desse polígono de elementos, os CRIAS se revezavam ora no palco, atuando, ora na "plateia", como observadores ativos da cena.

O trabalho corporal deve levar em consideração que um corpo significa por si só, sem que lhe seja dado um caráter especial de personagem. É necessário, portanto, o reconhecimento de próprio corpo, não apenas pelas habilidades, mas pelo que significa. É fundamental a observação de pequenos detalhes, como abertura dos ombros, distância entre ombros e orelhas, posicionamento da coluna, dos braços, ritmo dos movimentos, forma de caminhar e como isso cria uma estrutura comunicativa. Esse aspecto é de suma importância, uma vez que esses corpos, no diálogo com o texto, criam essa dramaturgia silenciosa.

Quadro 12 - Procedimento: do mais simples para o mais complexo

\section{Procedimento - Do mais simples para o mais complexo}

Iniciar os processos, considerando práticas de assimilação mais intuitivas. Poucas regras, poucas instruções, de modo que haja um aquecimento físico, disponibilidade e autoconfiança para proposições mais complexas. "Primeiro rastejar, depois engatinhar para depois andar."

Fonte: FUNDAÇÃO VALE, 2013, p. 32

\section{O CORPO}

Nesse sentido, o aquecimento levava em consideração os elementos contidos na "Técnica Klauss Vianna" 97 , apresentada por Neide Neves (2010), que desperta o autoconhecimento corporal para a constituição de uma forma comunicativa.

A técnica sistematiza o movimento das articulações do corpo em diferentes planos - baixo (próximo ao chão, deitado), médio (sentado, acocorado, ajoelhado), alto (de pé). O movimento deve ser contínuo, ou seja, um gesto

\footnotetext{
97 A Técnica Klauss Vianna foi sistematizada no início dos anos 1990, por Klauss Vianna, Rainer Vianna e Neide Neves, por meio da observação dos procedimentos utilizados pelo mestre em suas aulas e no trabalho de composição. Tive oportunidade de ser aluna da técnica nesse período.
} 
acontecendo de forma subsequente ao outro, como em contaminação. Esta articulação e subsequente mudança de planos deve acontecer pelo reconhecimento do peso nos apoios do corpo em oposição ao seu elemento de contato: os pés se opõem ao chão quando caminham, assim como a cabeça se opõe ao ar (Figura 7).

Figura 7 - Atores no trabalho de aquecimento das articulações do corpo.

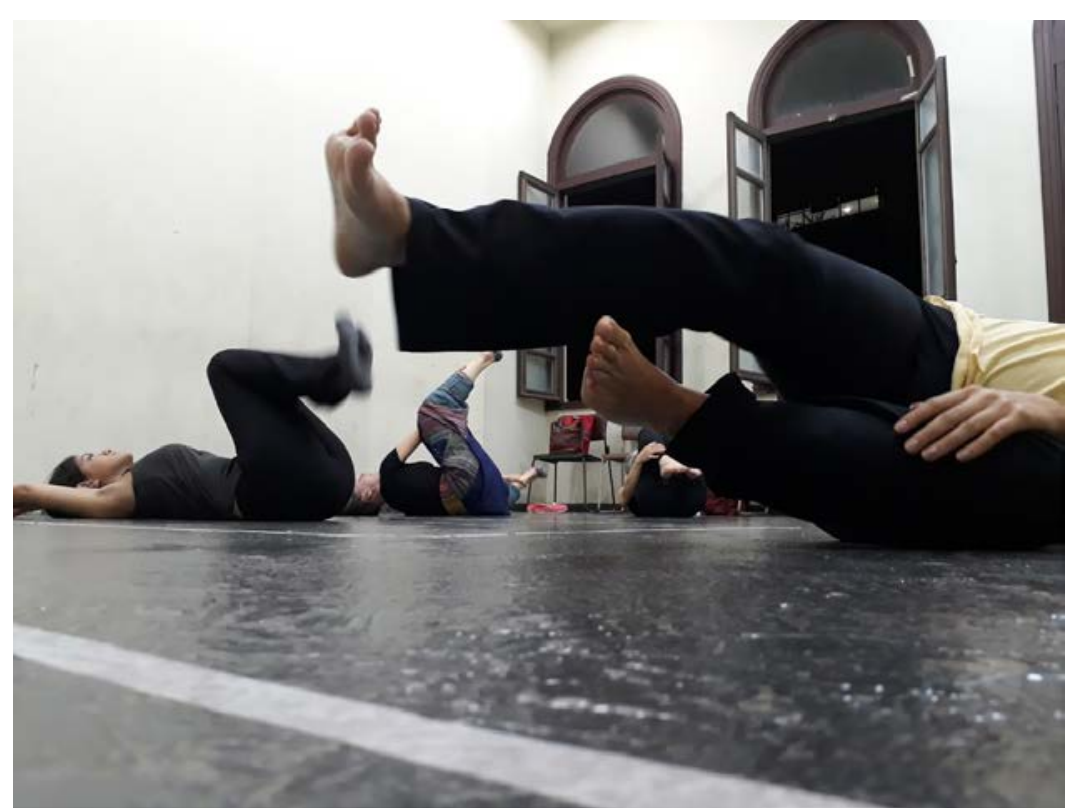

Fonte: Foto de processo de pesquisa. No quadro: Mariana Ayelen, Jany Canela, Adriana Azenha e Letícia Soares. [Autoria minha]

Essa é uma prática auxiliar no processo de preparação para a leitura comunicativa do corpo e no estudo da estrutura corporal e do alinhamento ósseo. É um trabalho no qual o CRIA e a CRIA lida com o seu corpo, articulando-o, alongando-o, manipulando-o ritmicamente, de forma a reconhecer diferentes caminhos para a construção de uma presença que promova a conexão entendendo presença como o exposto por Eugênio Barba (2012, p. 206), "[...] estar e se sentir vivo, e de transmitir essa sensação aos espectadores" (itálico do autor), o que ele denomina como organicidade. Essa presença do ator na cena que promove a conexão entre ele e o público.

Mas esse não é um processo óbvio. No mesmo capítulo, mais adiante, Barba (2012, p. 206) prossegue:

Mas às vezes o ator vive certas ações como sendo "orgânicas" quando nem o diretor nem o espectador sentem a mesma coisa. Também acontece o oposto: o diretor e os espectadores podem perceber como 
"orgânicas" ações que os atores vivenciam como "inorgânicas", duras e artificiais.

Essa disparidade de opiniões, ou sensações, vai contra a ingenuidade teatral e a fé na sintonia entre ator e espectador. Na verdade, não há sintonia entre a ação do ator e a reação do espectador, mas pode haver um encontro. É o efeito do encontro que decide sobre o sentido e o valor do teatro. (BARBA \& SAVARESE, 2012)

Portanto, o caminho de Fedra passa, necessariamente, pela construção desta consciência de encontro entre $O$ ator e o espectador. E, segundo Barba (2012), a preparação para esse encontro é possível pelo treinamento, que é o momento no qual o ator se prepara, se descobre, reconhece a energia, a presença, o bios, e reconhece a individualidade comunicativa do seu próprio corpo, uma vez que cada corpo apresenta diferentes possibilidades de gerar conexão.

Outro recurso de aquecimento empregado foi um jogo, aprendido com Cristiane Paoli Vieira, a Quito, intitulado "Movimento - imagem - ideia", exposto em sua dissertação de Mestrado:

\begin{abstract}
No "movimento-imagem-ideia", um movimento leva ao outro movimento naturalmente. A percepção do movimento criando imagens no espaço será observada tanto por quem produz o movimento quanto por que o vê. A intenção é o reconhecimento externo de quem o assiste, o espectador, ou seu parceiro, ou parceiros de cena, para que façam a leitura de imagens produzidas e, ao intuí-las, possam jogar. (VIEIRA, 2016, p. 55)
\end{abstract}

\title{
Esse jogo consiste em uma sequência de movimentos aleatórios que o
} ator executa sem que haja o objetivo de comunicar uma ideia particular, mas, uma vez constituída essa sequência, ela ganha uma força expressiva. Costumo dizer aos atores que algo "conecta". Não é necessário que essa conexão seja exprimível em palavras, que se refira a algo específico, mas simplesmente que "tenha sentido". Uma vez constituída essa imagem, o ator deve continuar a sequência de movimentos para que possa investigá-la ${ }^{98}$.

\footnotetext{
${ }^{98}$ Aqui fica clara a importância da experiência da cena por parte desse CRIA, um ator iniciante. Quando chega no ponto em que percebe a "conexão" que gera a imagem, tende a forçar a estruturação de algo conhecido, com o objetivo de deliberar uma ação dramática, acarretando a
} 
A continuidade do jogo é por meio da percepção da "plateia"; com os CRIAS, posicionados, observando se se estabelece a comunicação. Não estamos no campo da representação, não é necessário que essa imagem denote algo especificamente, nem se trata da pantomima, como disse, mas de algo que seja experimentado pelo próprio ator e que transite também para a plateia. Algo que traga uma conexão, seja pela cultura, seja de forma absolutamente subjetiva, seja derivado das idiossincrasias do corpo que se relaciona e dos corpos relacionados.

Sara Rojo (2005, p. 73) confirma essa ideia:

Entendo que o espaço da imagem apresentada no interior de um espetáculo está configurado tanto pelo físico quanto pelo psicossocial, e que conotações que possa oferecer dependem também da relação que estabeleça com outras linguagens e das formas em que é utilizado para construir a relação espetáculo/público.

Outro dado importante, era perceber a potencialidade comunicativa dos diferentes corpos, entendendo por corpo não apenas as dimensões, características físicas, mas também rítmicas e psicossociais. A idiossincrasia de cada corpo é um aspecto significativo fundamental. Sara Rojo refere-se a uma encenação de "Esodo" feita por "Pippo Delbono, apresentada no Teatro Argentina (Roma)" (ROJO, 2005, p. 74) na qual há no elenco "[...] um homem com síndrome de Down sobre o qual Pippo Delbono afirma” (IDEM, 2005, p. 74):

Bobò é sincero, seu corpo não pode mentir, cada pequeno movimento é o máximo que ele pode fazer uma vez que está naquele momento completamente presente. Cada corpo já carrega em si uma dramaturgia e não é possível ignorá-la.

A esse respeito, em $A$ Construção da Personagem, Constantin Stanislavski (2016, p. 71) afirma:

Mas quando pisamos o palco, muitas deficiências físicas menores chamam a atenção. Ali $O$ ator é esmiuçado por milhares de espectadores como que através de uma lente de aumento. A menos que tenha a intenção de mostrar uma personagem com defeito físico e nesse caso deve poder exibi-lo sem ultrapassar o grau certo - 0 ator deve mover-se com uma facilidade que aumente a impressão criada em vez de distrair o público dessa impressão. Para fazê-lo, precisará de um corpo saudável, em bom funcionamento, dotado de um controle extraordinário.

tentativa de imitação de alguma ação pré-existente. $O$ importante aqui é reconhecer a ação que brota do próprio corpo e não tentar induzir uma. 
Essa busca pelo corpo ideal, construída dentro da estética realista, "[...] a representatividade do referente externo" (ROJO, 2005, p. 74), a qual se refere Rojo não encontra mais a mesma ressonância na contemporaneidade. Também encontramos em Rojo uma alusão à reflexão de De Marinis, no que diz respeito a $\operatorname{Artaud}^{99}$ e o corpo:

Nosso corpo - diz então Artaud, o Momo - há muito tempo não é mais aquele originário, glorioso, imortal que foi dado no princípio. $\mathrm{O}$ corpo atual é o resultado de uma violação, de uma manipulação perpetrada que nos causa dano, em consequência da qual o homem hoje tem uma anatomia que deixou de corresponder à sua natureza (...) No final da vida e de sua trajetória artística, Artaud concede o Teatro da Crueldade como um grandioso projeto ético-político de insurreição física: trata-se de transformar (novamente) a cena em um "cozimento", no qual o homem (e já não apenas o ator) possa refazer sua própria anatomia, possa reconstruir seu corpo, recusando a "diferenciação orgânica" (como a denominou Jacques Derrida): um corpo sem órgãos. (DE MARINIS, 1999 apud ROJO, 2005, p. 74)

Esse espaço de reconhecimento da significação do próprio corpo, bem como a educação do olhar para a leitura do corpo do outro, começa a criar delimitações de reconhecimento de composição para os CRIAS. Essa percepção da construção do signo na relação é o cerne para a aquisição de consciência de dentro da cena.

\section{O ESPAÇO}

Há um outro dado nessa trajetória que precisa ser considerado: a relação do corpo com o espaço. Segundo Ipojucan Pereira,

A ideia de que a percepção das sensações espaciais ativa tanto o ambiente interno do organismo quanto o externo a ele, torna o corpo o campo de estudo por excelência para a compreensão das forças que organizam o espaço. (PEREIRA, 2015, p. 38)

Na Figura 14 e 15, as CRIAS Adriana Azenha e Miriam Limma estão em trabalho de aquecimento para a preparação da cena entre Enone e Fedra em diferentes espaços. A foto evidencia alguns aspectos do ambiente ${ }^{100}$ que não

${ }^{99}$ Antonin Artaud (1896-1948) artista e pesquisador de teatro, nascido na França. Propõe uma forma de teatro altamente crítica ao estabelecido em seu tempo. (SHISHIDO, 2015)

$100 \mathrm{Um}$ dado concreto facilmente experimentado nessa relação entre corpo e espaço: como trabalhamos em salas de ensaio diferentes, sempre havia a possibilidade de reflexão sobre um 
podem ser ignorados: chão e paredes desgastadas, mesa com bolsas e roupas, diferentes janelas abertas. Mesmo que essa não tenha sido uma escolha dramatúrgica a priori, ela necessariamente está incorporada à cena, uma vez que que faz parte da visualidade do espectador, como também a do ator em seu exercício de composição.

Figura 8 - Adriana Azenha e Miriam Limma ensaiando na sala 5 da Oficina Cultural Oswald de Andrade.

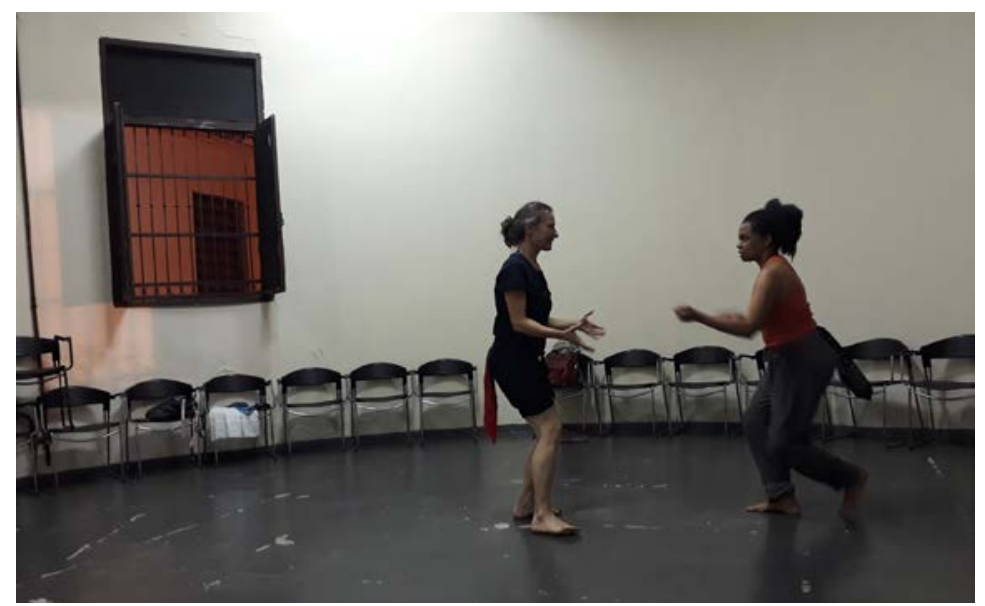

Fonte: Fotografia de processo. [Autoria minha]

Figura 9 - Adriana Azenha e Miriam Limma ensaiando na sala 22 da Oficina Cultural Oswald de Andrade.

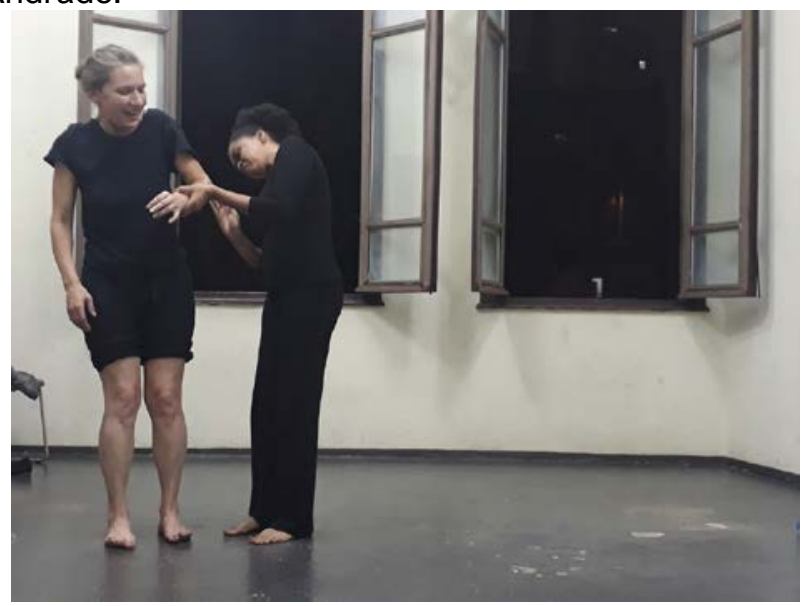

Fonte: Fotografia de processo. [Autoria minha.]

exercício feito em um ambiente ou em outro, a diferença nos corpos de quem estava na cena criando e a diferença da percepção dos observadores. 
Em um dos primeiros encontros do grupo para desenvolvimento de uma compreensão coletiva da visualidade da cena na composição de Fedra, foi proposto o trabalho com um tema de improvisação oriundo da pedagogia de Jacques Lecoq:

\begin{abstract}
Vocês voltam, depois de um longo período, para rever seu quarto de quando eram pequenos. Fizeram uma longa viagem para isso... vocês param diante da porta e a abrem. Como vão abri-la? Como entrarão? Vocês redescobrem o quarto: nada mudou, cada objeto está em seu lugar. Vocês encontram todas as suas coisinhas de quando eram pequenos: os brinquedos, os móveis, a cama. Essas imagens do passado voltam até vocês, até 0 momento em que o presente reaparece. E aí vocês deixam o quarto. (LECOQ, 2010, p. 61)
\end{abstract}

Durante a instrução, foi feita uma modificação em relação à proposta de Lecoq: ao invés de abrir a porta, a pessoa passaria por ela como se fosse por um portal. O objetivo era reconhecer o que mudaria no corpo antes e depois de passar por esse portal imaginário, quais as sensações causadas, e se havia uma percepção física de alteração de dimensão. Dentro dessa proposição, os CRIAS, à medida que ocupavam o lugar de plateia, apuravam o olhar para a leitura do ambiente constituído naquela relação entre o corpo, o espaço da sala de ensaio e o espaço reconstruído pela memória do atuante. Foram os primeiros passos para a construção de uma linguagem, de algo que se revelasse apenas pela presença.

Com isso, começamos a operar com jogos que estivessem imbuídos das situações dramáticas de Fedra.

\title{
4.3 A tessitura de Fedra
}

A aproximação com o texto precisa ser feita de forma delicada a fim de não incorrer em caricaturas e paródias. $\mathrm{Na}$ improvisação, sempre se pode recorrer ao conhecido, ao confortável. Por isso, a entrada, em Fedra, através de suas personagens, foi proposta quando os jogos de imagens trouxeram à luz muitas reflexões sobre os vícios e potencialidades corporais. 


\subsubsection{Quinta prática - Reunir soluções COMO-UNS (vide Quadro 9)}

- Jogo a partir dos actantes

A análise das linhas de força das personagens, apresentada no terceiro capítulo, serviu como base, dentro da pesquisa, não apenas como um processo de intelecção de texto, mas sobretudo para a criação de jogos de texto e subtexto que permitissem a recriação desses vetores no espaço, de forma que essas linhas pudessem produzir significados.

\section{Jogo 1: Pá}

Dois participantes deslocam-se do fundo para a frente do palco. Um, a partir da esquerda alta do palco, e o outro, a partir da direita alta, traçam uma linha reta em direção à esquerda baixa e à direita baixa, respectiva e simultaneamente. Depois, se deslocam para se unir no centro. Quando se encontram, olham-se a fim de encontrar uma expressão que represente a sílaba PÁ, ao mesmo tempo.

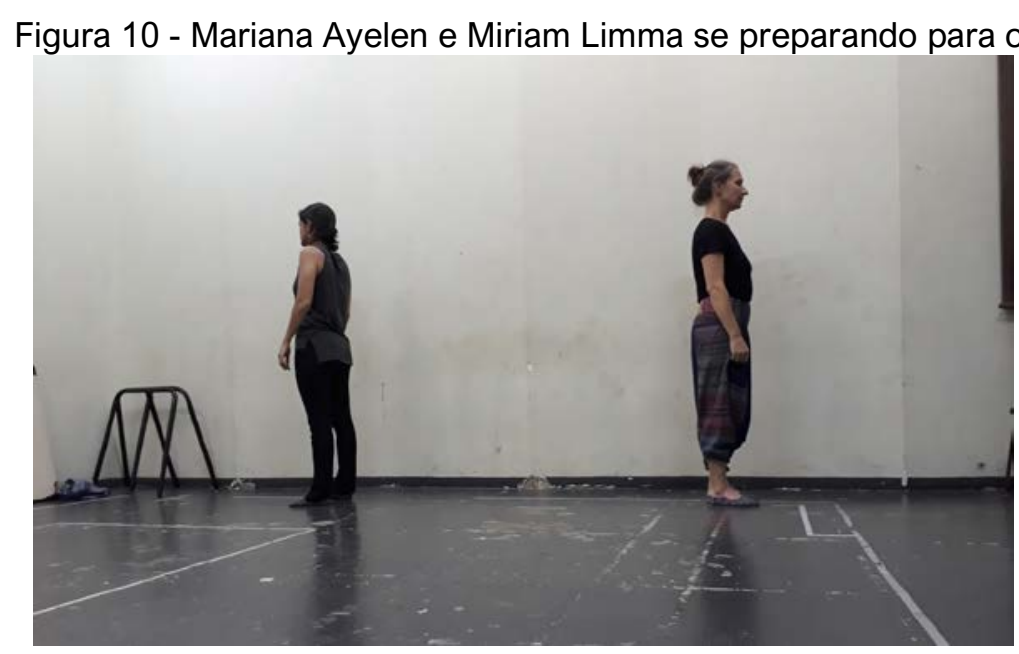

Fonte: Fotografia de processo. [Autoria minha.]

Esse é um jogo para treinamento de palhaço que aprendi quando estudei a linguagem do clown com a professora Mestra Cristiane Paoli, a Quito. Como todo jogo de clown, esse é suficientemente aberto para que a "falha" na regra proporcione a contracena e o fluxo criativo. Tudo que não está nas regras terá que ser resolvido pela cena. 
Nesse jogo, a busca da simultaneidade acaba por gerar um estado de atenção entre os participantes, para que as energias se equiparem e a chegada no centro baixo e o PÁ sejam simultâneos.

Além disso, proporciona uma tradução corporal com os actantes. Introduzi um elemento textual elíptico nesta relação. Eu sussurrava um subtexto diferente no ouvido de cada participante para que ele estivesse subjacente ao jogo silencioso.

\section{Subtexto 1:}

'Você precisa contar uma coisa muito importante para essa pessoa, mas está com muito medo, porque sabe que ela irá reprovar.'

\section{Subtexto 2:}

'Você ama muito essa pessoa e quer que ela saiba que você a apoiará em tudo incondicionalmente, mesmo que vá contra os seus princípios.'

Figura 11 - Adriana Azenha e Miriam Limma na finalização do jogo "Pá".

Fonte: Fotografia de processo. [Autoria minha.]

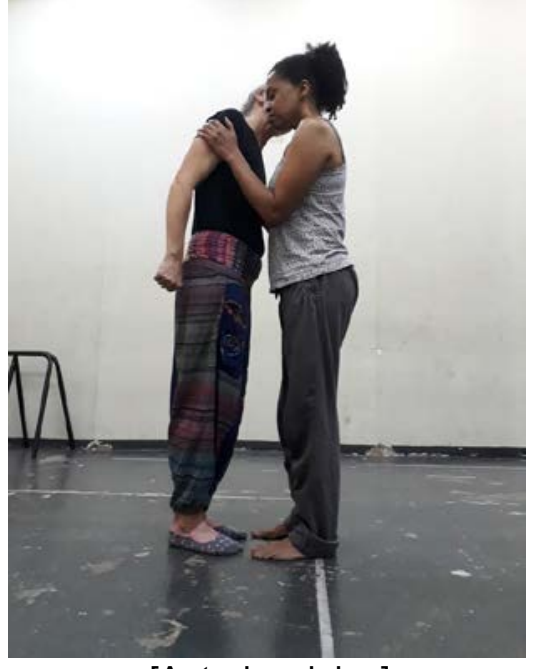

O jogo foi feito algumas vezes sem o subtexto e, após isso, foi introduzido o subtexto que proporcionou uma qualidade totalmente diferente de emoção. Com ele, o jogo adquiriu um novo corpo e os artistas cênicos que assistiam disseram que conseguiram estabelecer relações significativas: mãe e filha, pai e filho, amigos, Fedra e Enone. 


\section{Jogo 2: Pegar o rabo}

Jogado com dois participantes, coloca-se um lenço preso à na parte de trás do corpo, na cintura de cada participante, como se fosse um "rabo". O lenço deve estar de forma tal que o outro participante poderá tocá-lo e puxá-lo. O objetivo do jogo é que um pegue o rabo do outro. Ganha quem pegar primeiro.

Jogamos algumas vezes apenas seguindo as instruções, até o momento em que inseri os sussurros.

\section{Subtexto 1:}

'Você é Hipólito e ela é Fedra.'

\section{Subtexto 2:}

'Você é Fedra e ele é Hipólito.'

Esse jogo, feito dessa forma entre Jany e Rogério, gerou uma tensão muito forte. Jany/Fedra precisava manter as regras, portanto tinha que pegar o rabo de Rogério/Hipólito, e esconder o seu, mas, ao mesmo tempo, ela queria entregar o rabo, ceder o jogo. Por outro lado, Rogério/Hipólito não queria tocar em Jany/Fedra, pela enorme repulsa, mas não podia se desvencilhar de seu objetivo. Esse estado de coisas foi colhido no depoimento dos participantes.

O que víamos era uma tensão muito forte entre os dois. Nada aconteceu por muito tempo, no entanto, havia muita força ali; tanto Jany quanto Rogério dirigiam olhares muito significativos um para o outro.

Posteriormente, trabalhamos essa energia para a construção da cena em que Fedra revela seu amor a Hipólito.

A análise das funções dramatúrgicas e/ou dos actantes e a construção dos jogos serviram como orientadores no trabalho de improvisação das cenas para reescrita silenciosa de Phèdre, porém, o processo não foi linear. Não partimos da análise para o improviso, porque, às vezes, a análise vinha após ou junto com o improviso. 


\subsubsection{Sexta prática realizar soluções COMO-UNS (vide Quadro 9)}

Dentro do espectro dessa pesquisa, era significativo o câmbio constante de papéis, para tanto, cada CRIA teve a oportunidade de mediar alguns dos processos de reescritura, conforme o procedimento ser mestre-e-aprendiz da Pedagogia da Cooperação (Quadro 5). Neste aspecto, a construção de Fedra passa pelo desenvolvimento de uma linguagem, comum ao coletivo de criadores, que pressupõe um reconhecimento de percurso de identificação da relação entre corpo e espaço para a construção de uma dramaturgia corporal (ROJO, 2005), a fim de comunicar a essência contida na obra de Racine. A relação é, portanto, triangular: ator-atriz/CRIA $X$ espectador $X$ texto.

Segundo Cayuela,

La «reescritura» designa toda operación que consiste en transformar un texto A para llegar a un texto $B$, cualquiera que sea la distancia en cuanto a la expresión, el contenido y la función, así como todas las prácticas de "seconde main»: copia, cita, alusión, plagio, parodia, pastiche, imitación, transposición, traducción, resumen, comentario, explicación, corrección. ${ }^{101}$ (CAYUELA, 2000, p. 37)

E continua Graciela Balestrino:

En el mundo contemporáneo la reescritura (escritura sobre escritura)' no se refiere solamente a prácticas artísticas pertenecientes al ámbito de lo que se reconoce como "literatura", cuyo único soporte es la palabra; también en prácticas polisígnicas como el cine o el teatro (...) En el teatro debe deslindarse la reescritura dramática, circunscrita a textos dramáticos, de la reescritura escénica, hecho que ocurre cuando la puesta de una pieza dramática parodia o se convierte en contratexto de una puesta anterior de la misma pieza, para poner dos ejemplos extremos $^{102}$. (BALESTRINO, 2000, p. 221)

${ }^{101}$ A "reescritura" designa toda operação que consiste em transformar um texto A para chegar a um texto $\mathrm{B}$, qualquer que seja a distância quanto à expressão, ao conteúdo e à função, assim como todas as práticas de "segunda mão": cópia, citação, alusão, plágio, paródia, pastiche, imitação, transposição, tradução, resumo, comentário, explicação, correção. (Tradução minha) ${ }^{102}$ No mundo contemporâneo, reescrever (escrever sobre a escrita) não se refere apenas às práticas artísticas pertencentes ao campo do que é reconhecido como "literatura", cujo único suporte é a palavra; também em práticas polisígnicas como o cinema ou o teatro (...) No teatro deve-se diferenciar a reescrita dramática, circunscrita aos textos dramáticos, da reescrita cênica, fato que acontece quando a montagem de uma peça dramática parodia ou se torna um contratexto de uma obra dramática. colocação anterior da mesma peça, para colocar dois exemplos extremos. (Tradução minha) 
Quadro 13 - Procedimento: ser mestre-e-aprendiz

\begin{tabular}{|l|}
\hline \multicolumn{1}{|c|}{ Procedimento: Ser Mestre-e-aprendiz } \\
\hline $\begin{array}{l}\text { Propor uma inversão de papéis nos quais os jogadores focalizem e também possam propor } \\
\text { jogos. } \\
\text { No jogo cooperativo, a figura de mediação tem o nome de focalizador. } \\
\text { Focalizar um jogo é "ser como uma vela acesa num quarto escuro" }\end{array}$ \\
\hline
\end{tabular}

Fonte: (FUNDAÇÃO VALE, 2013, p. 32)

$\mathrm{Na}$ seleção de situações dramáticas para o início dos trabalhos de reescritura, voltei novamente a Barthes em seu Sobre Racine (2008), no qual ele apresenta trechos geradores de peripécia, partindo da ideia da ruptura do silêncio.

Fedra rompe o silêncio, para confessar o amor a Hipólito três vezes: diante de Enona (I,3), diante de Hipólito (II,5), diante de Teseu $(\mathrm{V}, 7)$. Estas três rupturas têm gravidade crescente; de uma e de outra, Fedra se aproxima de um estado cada vez mais puro da fala. (2008, p. 143). Foi feita uma divisão de CRIAS em três diferentes grupos. Dentro deles, uma das pessoas teria o papel de dramaturgista e os demais entrariam em cena. A ideia era que esse dramaturgista conduzisse o processo de constituição da dramaturgia silenciosa a partir da situação. Isso poderia ser feito por meio de um roteiro ou didascália escritos, ou simplesmente pela orientação oral do estabelecimento da cena. A situação escolhida foi a revelação de Fedra à Enone.

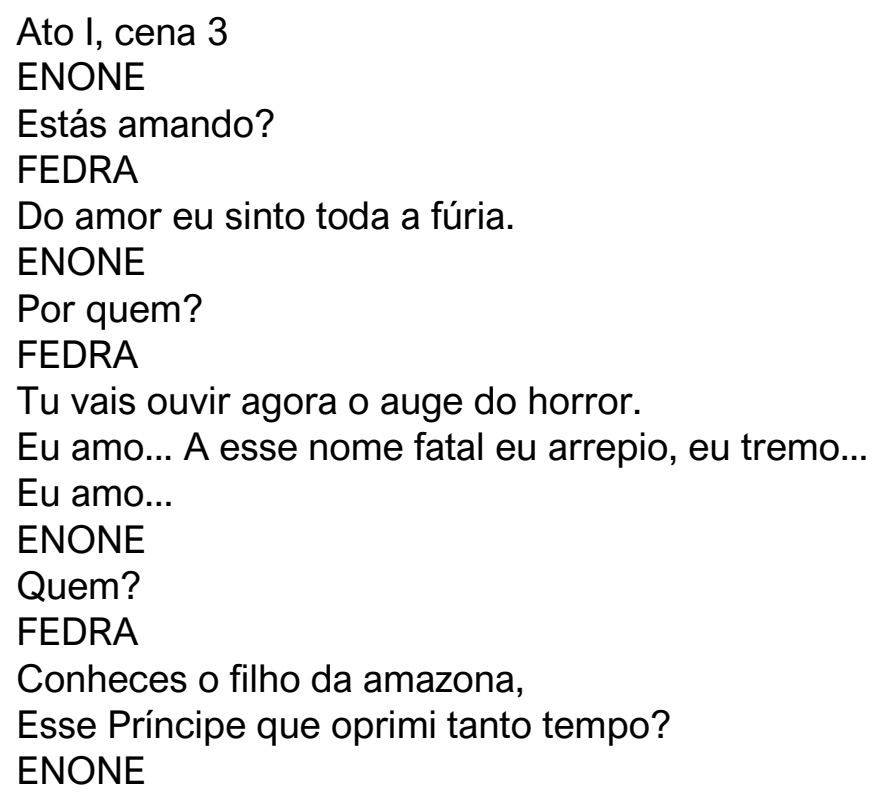


Grandes deuses! Hipólito?

FEDRA

Tu o disseste. (RACINE, Fedra, 2001)

Phèdre revela à Enone o amor que sente por Hipólito. Temos assim uma revelação indireta porque são as duas personagens falando de uma terceira que não está visível. Isso promove uma disrupção, uma vez que, no silêncio, o espectador só percebe as instâncias comunicativas da imagem de quem está na cena que, nesse caso, são Fedra e Enone. Na ausência de Hipólito na cena, mas sendo ele o assunto da cena, como personificá-lo no silêncio?

Na primeira improvisação, os atores criaram metáforas para as imagens, conforme o registro da didascália do CRIA Eduardo Aleixo:

\begin{abstract}
Entram Fedra e Enone. Fedra traz Hipólito nas suas costas, simbolizando o segredo que ela carrega. A princípio, não vemos o rosto de Hipólito. Enone busca saber o que é que aflige Fedra. Enone estende a mão. Fedra recusa. Fedra senta, ainda com Hipólito nas suas costas. Diante do olhar insistente de Enone, Fedra revela o seu segredo e tira Hipólito das costas. Hipólito fica em frente a Enone. O olhar de Hipólito é neutro. Hipólito, aliás, mantém a máscara neutra durante toda a cena. Enone tampa a boca de Fedra e esconde o rosto de Hipólito. Fedra cai de joelhos, abraçando Enone. Hipólito está de pé entre elas.
\end{abstract}

Após a apresentação, fizemos uma roda para a coleta de impressões. Nenhum dos CRIAS e das CRIAS na cena podia explicar o que construí. Apenas os observadores falavam a partir das perguntas:

\title{
"[...] O que você entendeu?"
}

CRIA $1^{103}$

"[...] O Hipólito estava machucado daí a Fedra resolveu carregá-lo. Essa talvez seja a volta do castigo de Poseidon."

CRIA 2

“[...] eu não sei muito bem... não entendi... não entendi porque ela o carregava nas costas. Ela era a Fedra? Eu acho que ele fazia a Enone por causa da relação das duas, mas não entendi o cara nas costas."

A defecção dessa improvisação está descrita na didascália 'simbolizando o segredo que ela carrega'. Para a constituição de uma comunicação simbólica

${ }^{103} \mathrm{Em}$ minhas anotações, não atribuí nomes às respostas. 
no silêncio, é necessário partilhar o código com o espectador. Como no caso da situação dramática apontada por Dario Fo (1998), que apresentei no terceiro capítulo, é preciso contar em qual contexto as imagens estão inseridas.

A partir disso, foi utilizado o recurso da animação de um objeto, no caso uma camisa masculina. O CRIA ou a CRIA que iria representar Fedra construía uma relação erótica observada pelo CRIA ou pela CRIA que representaria Enone. Entretanto, como essa camisa tinha sido usada pelo próprio Hipólito anteriormente, pôde ser configurada uma metáfora visual cuja leitura é acessível ao espectador.

A ideia de utilização de um objeto está conectada a uma afirmação de Jarry, referida por Brunella Eruli (2008, p. 22): “[...] não possuindo um corpo real e um psiquismo, pode assumir todos". Jarry diz isso se referindo à marionete como o ator ideal, no entanto, o objeto apresenta essa mesma maleabilidade.

Figura 12 - Jany Canela improvisando com o objeto cênico camisa.

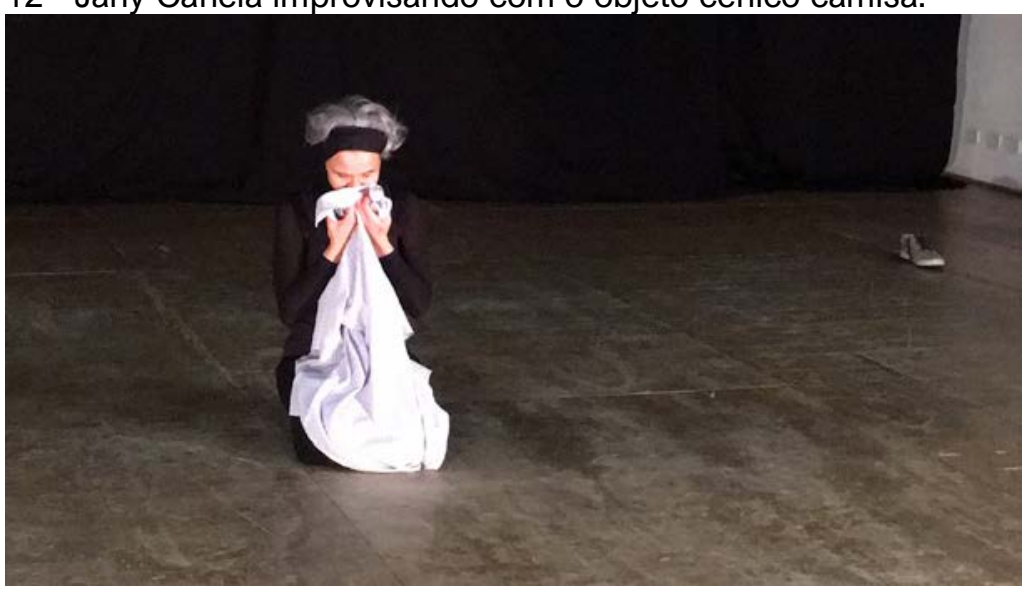

Fonte: fotografia de processo de trabalho. Autoria: Geraldo de Lima

Figura 13 - Dani Alba improvisando com o objeto cênico camisa.

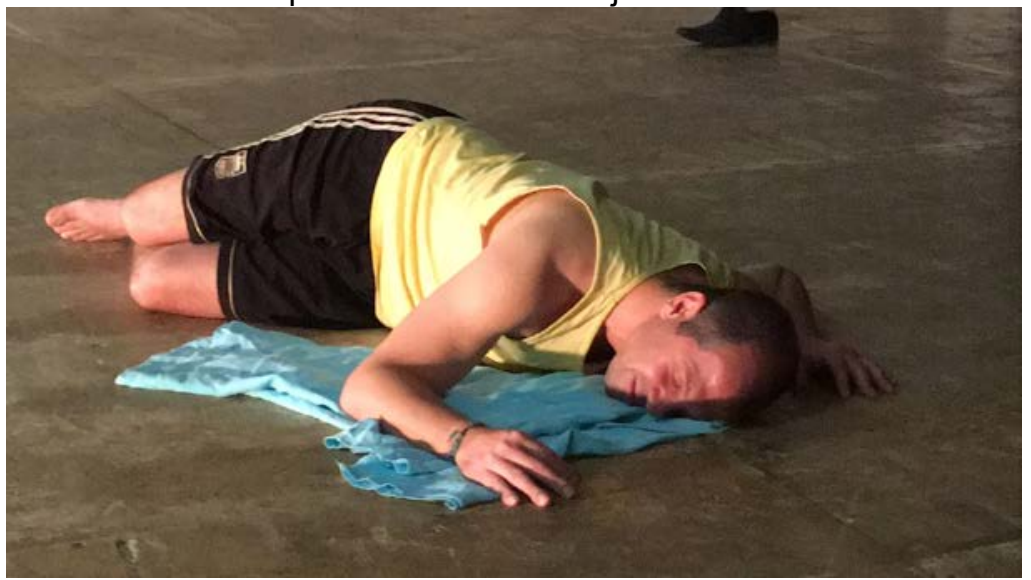

Fonte: fotografia de processo de trabalho. Autoria: Geraldo de Lima 


\subsubsection{O narrativo}

Desde o início do trabalho com Fedra, eu observava atentamente, na cena inicial, um diálogo no qual Hipólito revela sua preocupação pela ausência de Teseu e Terâmeno e narra sobre os lugares que percorreu em sua busca. Eu lia a cena, mas não conseguia imaginá-la como uma sequência de ações. No entanto, tinha convicção de que no decorrer da pesquisa iríamos encontrar um espaço no qual o improviso traria a solução cênica e que a constituição silenciosa daquela situação dramática seria elucidada.

No segundo capítulo desta pesquisa, quando discorri sobre o épico, citei o aspecto de algumas construções narrativas no texto, o que gera uma quebra no diálogo dramático. Foi quando reconheci um conceito novo, vindo do cinema, mas em co-relação no teatro: a diegese. Segundo Pavis (2015, pp. 96-97), a diegese se "opõe" à mimese aristotélica pretendida para a poesia dramática, uma vez que não é a imitação de uma ação, mas se coloca em uma relação narrativa com o sujeito a ser "imitado". Acrescento a esse o comentário de Lígia Fachin:

\footnotetext{
O que chama a atenção já de início no teatro, é que se pode distinguir entre o que é mostrado em cena e o que não o é, entre espaço cênico e extra-cênico, entre visível e invisível. A essas duas facetas de uma só realidade, a esse perceptível que se opõe a um não-perceptível. (FACHIN, 1998, p. 103-104)
}

Em seu artigo, ela opõe a denominação mimético a diegético. E continua, citando o semiólogo Michael Issacharoff:

\footnotetext{
O espaço mimético é transmitido sem mediação; o espaço diegético, ao contrário, é mediatizado pelos signos verbais (o diálogo), comunicado pois verbalmente e não visualmente .... Enquanto o espaço mimético é apreendido diretamente pelo público, o espaço diegético é unicamente referido no discurso das personagens, limitando-se a uma existência verbal, não visual. (ISSACHAROFF ${ }^{104}$, 1985, p. 72-73 apud FACHIN, 1998 p. 104).
}

Vamos ao exemplo dessa estruturação narrativa no texto inicial $(I, 1)$, quando Hippolyte e Théramène conversam sobre o que supõem que acontece a

${ }^{104}$ ISSACHAROFF, M. Le spectacle du discours.Psrís: Corti, 1985 
Thésée:

TERÂMENO

Não há mais lugares, senhor, onde buscá-lo.

Pra acalmar os teus justos receios,

Percorri os dois mares que separam Corinto;

E perguntei por Teseu em todas as costas

Das quais se vê o rio Aqueronte mergulhar no reino

Onde habitam os mortos

Visitei a Élida e, partindo do Tenaro,

Cheguei ao Egeu, que um dia refletiu a queda de Ícaro.

Com que nova esperança ou em que terras mais felizes

Pensas, ainda, senhor, descobrir sinais dos seus passos?

$E$, além do mais, quem poderá dizer se o Rei, teu pai,

Deseja desvendado o mistério dessa ausência?

Bem pode ser que enquanto tememos por sua vida

Ele, tranqüilo, se esconde; e nos esconde seus novos amores;

Ele, tranquilo, desfruta uma nova e desvairada amante.

HIPÓLITO

Para, caro Terâmeno, e respeita Teseu.

Liberto já dos seus erros de jovem

Obstáculos indignos não mais o seduzem:

Fedra Ihe tirou do peito a inconstância fatal

E há muito não tem, nem teme, mais rivais.

Enfim, procurando-o, eu cumpro o meu dever

$E$ fujo de lugares em que não quero estar.

(RACINE, 2001, pp. 13-14)

Nesse momento, a ação realizada pelas duas personagens é dialogar, mas o assunto do diálogo refere-se a uma ação acontecida no passado. Théramène narra o que ele fez para encontrar o rei, mas não o que faz na ação da cena. Hippolyte, por sua vez, tem como ação presente advertir Théramène, mas essa advertência é um discurso sobre a relação entre Thèsée e Phèdre. Mesmo quando Hippolyte fala de si - "fujo de lugares em que não quero estar" - , não é em função da ação, mas de uma reflexão. Esse recurso narrativo é diegético. $E$ nesse momento veio o espanto.

Há duas fases do espanto: a primeira aconteceu quando nós realizamos várias improvisações com o texto e não nos atentamos a essa diegése; na verdade, fomos percebendo a dificuldade da tradução do texto para o silêncio e quanto o épico se avizinhava da cena. Pensamos em solucionar esta dificuldade de constituição da cena por meio do texto corporal com projeções, objetos, elementos externos, para conseguir narrar um acontecimento fora da cena, mas 
indispensável para a compreensão do contexto. Ficou claro que apenas o corpo não supria as necessidades que o texto impunha. Esse foi também um momento de frustração, uma vez que colocava uma inviabilidade ao silêncio. Tínhamos o recurso das Libras - Língua Brasileira de Sinais -, mas esse é um recurso textual, é uma língua como a Língua Portuguesa. Não é ação.

Foi então que eu percebi um detalhe da normatização proposta por D'Aubignac e seguida fielmente por Racine em Phèdre:no poema dramático tudo deve ser apresentado pela boca dos atores, inclusive o cenário. Observando a enunciação:

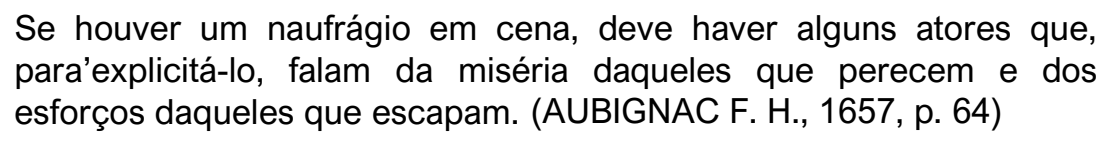

No trecho apresentado acima, eu não vejo a representação da miséria, eu vejo a narração de como ela acontece. Eu posso traduzir essa cena silenciosamente, mas, para isso, é necessário criar um texto constituído de ações, por exemplo: 'Um homem se apoia no parapeito do casco do navio olhando para baixo e grita'. Apoiar, olhar e gritar são verbos que determinam ações físicas. $O$ modo como cada corpo realizará essas ações cabe à arte criativa da atriz ou do ator, mas o quê deve ser feito está posto. Por outro lado, se observarmos um trecho do diálogo entre Terâmeno e Hipólito:

Não há mais lugares, senhor, onde buscá-lo.

Pra acalmar os teus justos receios,

Percorri os dois mares que separam Corinto;

(RACINE, 2001, p. 13, grifo meu)

Quais as ações físicas determinadas pelos verbos buscar, acalmar e percorrer, dentro desse contexto ${ }^{105}$ ?

Em um dos ensaios, a CRIA Adriana Azenha observou, "mas essas ações todas estão no passado, nada está acontecendo no momento da cena. Ele (Terâmeno) apenas está contando para Hipólito o que já fez".

$\mathrm{E}$ eu digo que o silêncio delimita a ação no presente. $\mathrm{O}$ que o espectador 
vê no corpo do ator e da atriz é o que acontece no momento da cena. Mesmo o recurso da memória, é presentificado. Não há passado na cena silenciosa.

Além disso, Terâmeno se refere a ações relativas a busca de Teseu, personagem que está fora do diálogo ou, dizendo de outro modo, personagem que não está presente nas ações físicas entre Terâmeno e Teseu. O silêncio é concreto, ele só se realiza na ação e, reiterando a definição de dramático, observada ao longo dessa dissertação:

A representação por atores de uma ação que, a partir de uma situação dada, opõe dois ou mais personagens que evoluem segundo as leis de sua própria lógica.

E, nesse ponto, D’Aubignac opõe-se à Poética de Aristóteles. Ele retira do texto a ação, o drama, e a transforma em discurso.

\subsection{Sétima prática - realizar projetos de Cooperação (vide Quadro 9)}

Após a aprendizagem da Pedagogia da Cooperação, a proposição era desafiar-se, realizar um projeto feito em colaboração. Esta pesquisa já foi esse projeto. Nos dedicamos a reconhecer os meandros de Fedra e esta dissertação é justamente para relatar o meu ponto de vista sobre os acontecimentos.

Como espetáculo, Fedra ainda tem um caminho a trilhar, uma vez que também se fez necessário o estudo do silêncio a partir de estruturas narrativas e não apenas dramáticas, como pudemos verificar no trajeto da pesquisa. Apresento aqui um fragmento do trabalho de construção coletiva de dramaturgia usando como ferramenta os corpos, o espaço, a escrita para criar um diálogo silencioso. Uma pequena parte do que gestou nossa reescritura em colaboração de uma tragédia sem palavras.

II Ato, cena 5

FEDRA

Sim, Príncipe, eu definho, eu queimo por Teseu.

Eu o amo não como o viram as chamas dos infernos, Adorador volúvel de mil tentações várias 
Que desonrou a alcova até do deus dos mortos.

Mas o fiel, o soberbo e mesmo quase selvagem,

Encantador, jovem, arrastando atrás de si os corações,

Tal como são pintados os nossos deuses.

Igual a eu te vejo aqui.

Igual a ti no porte, nos olhos, na linguagem.

Esse mesmo rubor coloria seu rosto,

Quando, dominando as ondas, chegou à nossa Creta

Atendendo ao anseio das filhas de Minos.

Que fazias, então? Por que, arrebanhando a elite dos heróis da Grécia,

Teseu não trouxe Hipólito consigo?

Talvez, jovem demais ainda, não te era permitido

Subir no barco que transportava Teseu a nossas praias.

Ah, terias sido tu o destruidor do monstro de Creta,

Dentro do labirinto terrível em que vivia.

Para te evitar os descaminhos

Minha irmã teria dado a ti o fio fatal.

Ah, não; eu a teria antecipado nesse intento;

$\mathrm{O}$ amor o teria sugerido a mim primeiro,

E seria eu, Príncipe, seria eu quem te ajudaria

Nos meandros sem fim do labirinto;

Que riscos eu não aceitaria por esse rosto mágico?

Só um fio, porém, não deixaria tranquila tua amante;

Companheira do perigo que deviam enfrentar,

Fedra mergulharia a teu lado no labirinto invicto.

E salvava-se contigo ou contigo se perdia.

HIPÓLITO

Deuses! O que é que eu ouço? Senhora, se esquece acaso

Que Teseu é meu pai e que és sua esposa?

FEDRA

Por que julgas tu que o tenha esquecido, Príncipe?

Dou a impressão de ter perdido o sentido da honra?

HIPÓLITO

Senhora, me perdoa. Confesso, com rubor,

Ter entendido errado palavras inocentes.

Envergonhado, nem sei mais como olhar-te.

Eu parto... (RACINE, Fedra, 2001)

\section{Reescritura: A rainha se ajoelha}

\section{Didascália:}

Fedra é uma mulher franzina, com uma postura altiva que Ihe alonga a estatura. Corpo magro, desprovido de curvas. $O$ queixo posicionado de maneira levemente erguida, sem exageros. O posicionamento da cabeça dessa forma, parece bastante natural no contexto, mas desenha um porte soberano, mesmo em um corpo tão pequeno.

Hipólito é um homem forte, músculos delineados; no meio da grossa panturrilha, há uma linha tatuada em toda a circunferência, como um desenho tribal. Coluna ereta, queixo erguido, mas nesse corpo há tensão. Sua postura é desconfortável, 
os braços caem tesos pela lateral do corpo. Sua figura se assemelha a um desenho egípcio.

Essas duas personagens se observam frente a frente. O espectador está posicionado de forma a ver o perfil esquerdo de Fedra e o direito de Hipólito. Lentamente os dois se movimentam no sentido de se aproximarem. Hipólito se ajoelha, nesse gesto sua cabeça também pende para baixo, o olhar em direção ao seu próprio coração em sinal de reverência. O olhar de Fedra, antes altivo, ganha languidez, ela se dirige a Hipólito, quase em câmera lenta, seus joelhos bambeiam como se fossem se dobrar, o gesto é pequeno, mas perceptível. Ela continua sua caminhada e flexiona os joelhos até tocarem o chão. Hipólito e Fedra permanecem frente a frente, só que agora próximos e ambos ajoelhados. Fedra, em um gesto suave, sinaliza delicadamente com a mão o queixo de Hipólito para que erga sua cabeça e seu olhar encontre o dela. Ele tem um gesto rápido de impulsão da coluna para trás. Ela se levanta lentamente, sua cabeça pende para baixo, seu olhar se direciona para o seu coração. 


\section{Imagens}

Figura 14 - Sequência do exercício sobre Fedra $(I I, 5)$ com Dani Alba e Jany Canela

1

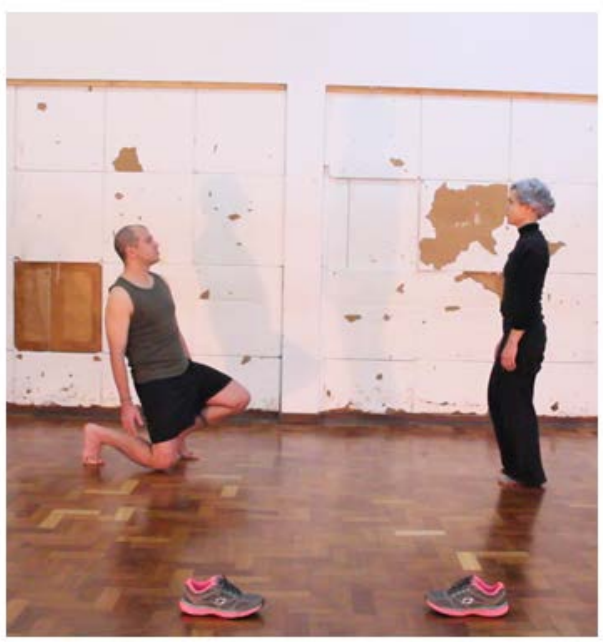

3

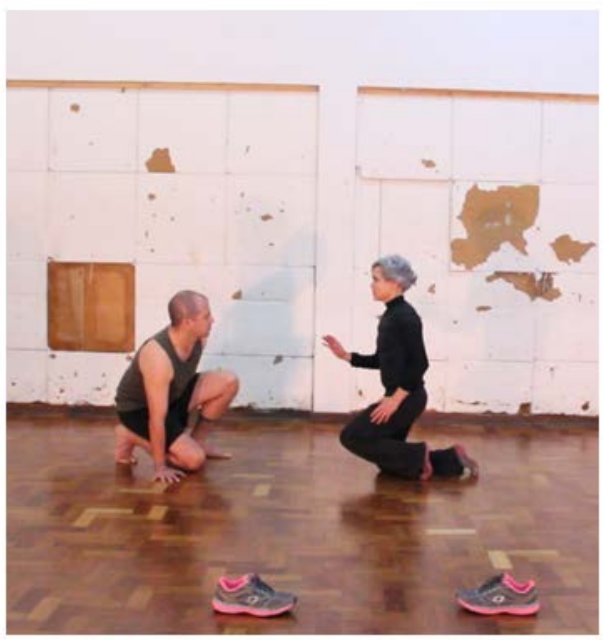

2

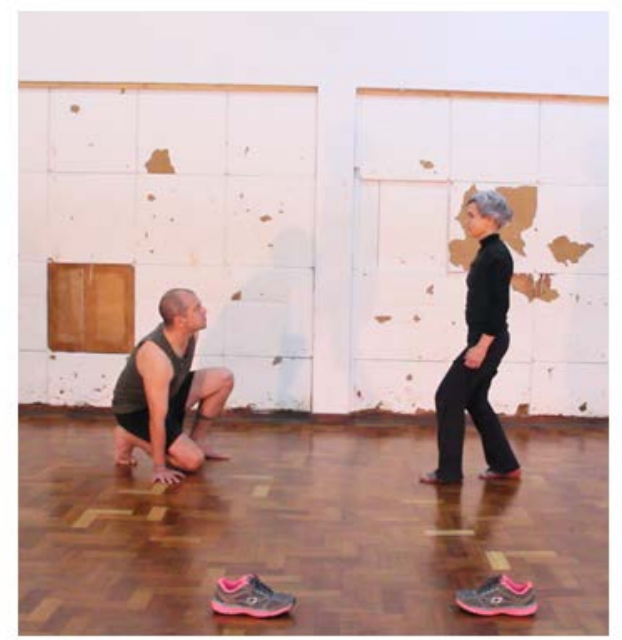

4

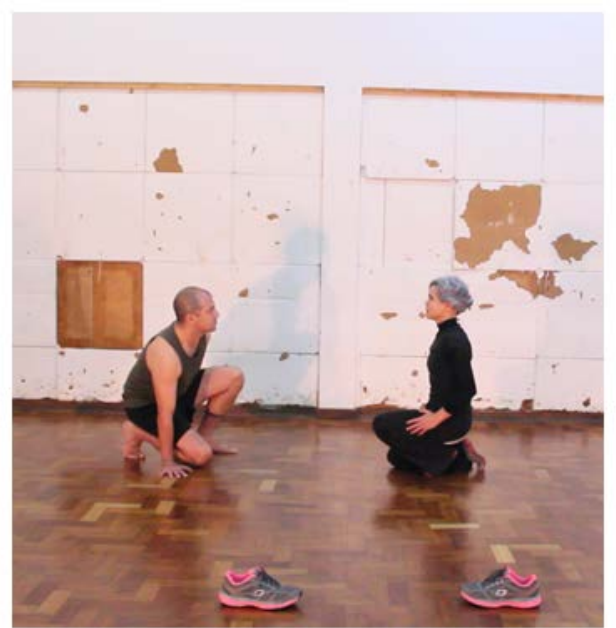

Foto: fotografia de processo. Autoria Juliana Keiko.

A descrição física de Fedra e Hipólito parte das características de Jany Canela e Dani Alba, que se amalgamam com as proposições das personagens e acabam por criar a imagem daquilo que o espectador lê como sendo Fedra diante de Hipólito. A situação dramática é mantida - Fedra revela seu amor a Hipólito, com o objetivo de ser correspondida. Hipólito, por sua vez, fica horrorizado com a repentina revelação daquela que se portou como sua algoz, no relacionamento entre ambos, no entanto, a significação dos corpos acaba por gerar uma leitura particular das personagens. Seria diverso se Fedra fosse uma mulher alta e 
opulenta, e Hipólito, por sua vez, franzino. Entretanto, Fedra não deixa de ser Fedra: ela subsiste ao corpo do ator. A criação pressupõe, portanto, o reconhecimento das estruturas significativas que revelam Fedra contida em Phèdre. 


\section{CONSIDERAÇÕES FINAIS}

O que se apresentou de mais fascinante neste estudo sobre a dramaturgia do silêncio é que, mesmo que dramaturgos e dramaturgas não o prescrevam, o silêncio está posto de forma indelével dentro da composição. Atores e atrizes são coautores à revelia de quaisquer prerrogativas do texto. $O$ teatro é um acontecimento polisígnico, ele reúne palavra, corpo, tempo, espaço. A leitura, pelo espectador, acontece amalgamando todos esses elementos. O corpo de um ator ou atriz passa a compor com o som que ele emite, com a cenografia, com o ambiente, com a pessoa sentada na cadeira ao lado. O teatro é uma experiência integral o que inclui uma série de acontecimentos silenciosos coparticipantes.

Se uma atriz ou ator, ao interpretar Fedra, estiver com gripe, por exemplo, associa uma série de informações que não estão presentes no texto, mas que impactam as relações da personagem na cena. Uma simples gripe. Olhos vermelhos e marejado, o corpo um tanto lento e um pouco curso. Apenas isso já é capaz de transformar a rainha em vassala, sem que uma única palavra seja emitida. O silêncio quebra as possibilidades hierárquicas que colocam ora o texto ora a encenação como o centro em torno do qual gira o teatro. Não há centro ou ele está espalhado por tudo.

Disse algumas vezes que essa pesquisa iniciou com o propósito de investigar uma partitura corporal que estava escrita subliminarmente no texto de dramaturgia dramática, no caso, Phèdre, de Racine. O que acontece é que, mesmo que se desenhe uma partitura, há um sem número de pequenas ações que tem comunicabilidade própria e não há meio de negá-las. O processo de execução da investigação do silêncio em Phèdra-Fedra acabou por proporcionar um olhar mais fino sobre o fato coletivo do acontecimento teatral uma vez que o teatro é uma experiência entre pessoas, como disse Márcio Abreu em trecho de entrevista citada na abertura dessa dissertação. E essa é uma consciência agregadora e que elucida a relevância do reconhecimento das individualidades e de sua potencialidade nesse tecido. Isso leva a um caminho que é trazer à luz como cada individualidade colabora na composição. Cada pessoa que pisa na 
cena precisa ter lucidez de como contribui na composição dramatúrgica. Essa pesquisa trouxe apontamentos dessa realidade, mas tornou imprescindível uma investigação aprofundada dos meandros de como isso acontece. O reconhecimento das unidades que compõe o silêncio em processo similar à construção de poéticas a partir do entendimento da composição das palavras. A ciência do desenho do gesto no espaço.

No último encontro do coletivo para essa fase de trabalho com Fedra, porque seguiremos ainda investigando suas possibilidades, sentamos para ler Phedra's Love ${ }^{106}$ de Sarah Kane, uma dramaturga inglesa, que faleceu em 1999, mas que, se fosse viva, teria um ano mais que eu. Kane nos apresenta uma leitura muito peculiar da história da rainha que se apaixona pelo enteado. A Inglaterra vive uma monarquia, em vista disso, a representação que a autora faz da família de Teseu passa por esse olhar, é o caldo cultural no qual ela estava mergulhada. Na primeira cena, Hipólito está sentado em um quarto grande e escuro, iluminado apenas pela luz da televisão e imundo. Restos de vários dias de fast food se espalham. Ele pega uma meia no chão, cheira, veste a mão e bate uma punheta com ela. Essa é a imagem que Kane projeta de um príncipe, ou melhor dizendo, essa é a representação de um príncipe que ela propõe. E é uma representação silenciosa, mas, mesmo assim, bastante prolixa.

Eu disse inúmeras vezes ao longo dessa dissertação o quanto a cultura interfere no nosso olhar sobre o mundo, em nossa leitura, e, consequentemente na sua representação. Nas mimeses que praticamos dele. A cultura é essa rede de conversações na qual nos inserimos. E essa rede é vasta e complexa. E tudo nos entra pelos poros silenciosamente sem que tenhamos, na maior parte das vezes, a possibilidade de reconhecimento e de filtros. A cada passo que damos, nossos receptores estão invisivelmente ligados e captando imagem, som, gesto, representação do que nos cerca. O teatro já não é mais o grande mecanismo narrativo, mas continua fazendo parte desse sistema. $O$ rei continua contratando alguém para deliberar como deverá ser a dramaturgia, mas para sistemas mais 
efetivos e de muito maior alcance. Os meios mudaram, mas quem detém a narrativa ainda detém o poder.

No momento em que escrevo isso, o site do jornal argentino El País (OLIVEIRA, 2018) dá a notícia de a peça de teatro O Evangelho Segundo Jesus Cristo, Rainha do Céu "escrita e interpretada originalmente pela britânica Jo Clifford, mulher trans e católica praticante" e que, aqui no Brasil, é interpretada pela atriz transexual Renata Carvalho, foi censurada pela prefeitura de Garanhuns, mesmo fazendo parte do Festival de Inverno da cidade (FIG), sendo escolhida pela curadoria. Essa peça já sofreu retaliação e tentativa de censura em muitos lugares nos quais foi realizada. Em Taubaté, dois policiais permaneceram na sala para garantir a integridade física da atriz, que foi ameaçada, diz o jornal. A Constituição Federal do Brasil de 1988 promulga "é livre a expressão da atividade intelectual, artística, científica e de comunicação, independentemente de censura ou licença", mas permitir ou não, dar voz ou não a determinado grupo de artistas não é uma questão legal, mas uma questão de domínio. $\mathrm{E}$ a cultura dominante não serve às leis, ela as altera.

Eu gostaria de dizer que vivemos um momento conturbado para ler a notícia de um episódio como esse, mas quando não o vivemos? Em que momento da história não há luta pelo direito de representação do mundo?

$\mathrm{Na}$ França do século XVII, os artistas de rua foram censurados em suas performances porque não detinham os privilégios de representação e fizeram do silêncio a manutenção da sua arte e, sobretudo, de seu modo de vida. No entanto, não foi apenas isso, esse ato de resistência foi o motor de propulsão de uma revolução estética que, no devido momento histórico, deu voz a quem não a tinha.

Quando um coletivo de artistas brasileiros realiza Fedra em silêncio, extirpando do texto sua maior expressão, a palavra, essa mesma que erigiu Racine como um dos maiores escritores da França, e que oprimiu tantos outros, de um modo transverso, colocamos em Racine a mesma mordaça que ele, de certa forma, ajudou a impingir aos artistas das feiras. Eles foram proibidos de falar nos palcos e agora, retiramos também de Racine essa potência. Essa não foi a intenção original. Eu queria que fosse, queria configurar deliberadamente $o$ ato político dessa pesquisa, mas tudo começou como uma "simples" questão 
estética. E com isso aprendi, dia após dia, gesto após gesto, o mais clichê que se pode aprender na arte: estética e política não se dissociam.

Isso não é uma condenação a Racine. É apenas uma compreensão de contexto. A arte que aprendemos a admirar foi financiada pelos governos. Isso não diminui o valor da obra dos artistas, mas mostra muito da nossa leitura de mundo.

E é devido a nossa leitura de mundo que estudamos teatro pelo texto e não pela cena. A ideia que temos de teatro é constituída pela dramaturgia que chega até nós por intermédio das palavras postas no papel. Mas há muito mais teatro que isso, muito mais encenações ao longo da história da humanidade. Entretanto o silêncio não tem um registro que perdure. $O$ meio pelo qual ele transpõe o tempo, o vídeo, é recente, e acarreta uma mudança estrutural à medida que modifica a mídia. Interfere na leitura.

É sempre uma questão de leitura e tradução. Lemos um Aristóteles com origem um tanto controversa, mas que interfere na maneira que nós ocidentais entendemos ser a forma certa de contarmos histórias. Depois fomos influenciados por inúmeras traduções, leituras e versões dessa mesma poética que propunham modus de conduta e um ethos específico para a escrita. E isso tudo começou porque era assim que Aristóteles via o teatro de seu tempo, ele selecionou as melhores práticas e escreveu a partir de sua leitura do fenômeno, não quer dizer que fosse assim e não quer dizer que assim fosse o certo. Mas o teatro, aquele formado pelos gestos dos atores, e não de atrizes na cena, que não pode ser registrado sem que, com isso, haja a interferência de uma leitura específica e, consequentemente, uma tradução, é perceptível no momento exato do seu acontecimento e o silêncio evidencia essa precariedade.

Tudo que aqui foi escrito aqui, é a minha leitura das coisas. É a tradução que consigo fazer a partir do impacto nas minhas retinas.

O resto são palavras. 
Referências

ARISTÓTELES. Poética. (A. M. Valente, Trad.) Lisboa: Fundação Calouste Gulbenkien, 2008.

ARISTÓTELES, HORÁCIO, \& LONGINO. A Poética Clássica. (J. Bruna, Trad.) São Paulo: Pensamento-Cultrix, 2014

AUBIGNAC, F. H. La pratique du théâtre: oeuvre tres-necessaire a tous ceux qui veulent s'appliquer a la composition des poëmes dramatiques. Paris: Chez Antoine de Sommaville. Acesso em 28 de agosto de 2018, disponível em https://gallica.bnf.fr/ark:/12148/bpt6k107980n/f11.item.r=aubignac, 1657.

BALESTRINO, G. El perro del hortelano de Pilar Miró (sobre la transposición fílmica de un clásico del teatro español). Cuaderno de Humanidades N12, 221-231, 2000.

BARBA, E., \& SAVARESE, N. A arte secreta do ator: um dicionário de antropologia teatral. (P. F. MENDONÇA, Trad.) São Paulo: É Realizações, 2012 BARTHES, R. Aula (14ª ed.). (L. PERRONE-MOISÉS, Trad.). São Paulo: Cultrix, 1989.

BARTHES, R. Crítica e verdade ( $3^{a}$ ed.). (L. PERRONE-MOISÉS, Trad.) São Paulo: Perspectiva, 2007.

BARTHES, R. Sobre Racine. (M. M. AGUIAR, Trad.). São Paulo: Martins Fontes, 2008.

BENJAMIN, W. Magia e Técnica, Arte e Política: ensaios sobre literatura e história da cultura. Obras escolhidas. (Vol. 1). (S. P. ROUANET, Trad.) São Paulo: Brasiliense, 1987.

BERTHOLT, M. História Mundial do Teatro. (6 ${ }^{a}$ ed.). (M. P. ZURAWSKI, J. GUINSBURG, S. COELHO, \& C. GARCIA, Trads.) São Paulo: Perspectiva, 2014. BOAL, A. Jogos para atores e não-atores ( $2^{\mathrm{a}}$ ed.). Rio de Janeiro: Civilização Brasileira, 1999.

BOAL, A. Teatro do oprimido e outras poéticas políticas. Rio de Janeiro: Civilização Brasileira, 2008.

BONASSIES, J. Les espectacles forains et la Comédie française: le droit des pauvres avant et aprés 1789, les auteurs dramatiques et la Comédie Française au dix-neuvième siècle. Paris: E.Dentu, Libraire-Éditeur, 1875. 
BORHEIM, G. Brecht, a estética do teatro. Rio de Janeiro: Graal, 1992.

BRANDÃO, J. d. Mitologia Grega. (Vol. II). Petrópolis: Vozes, 1986.

BRANDÃO, J. d. Mitologia Grega. (Vol. III). Petrópolis: Vozes, 1987.

BRECHT, B. O teatro dialético. (L. C. MACIEL, Trad.) Rio de Janeiro: Civilização Brasileira, 1967.

BRECHT, B. Escritos sobre teatro. (J. HACKER, Trad.) Buenos Aires: Nueva Vision, 1970.

BRECHT, B. Teatro Completo. Rio de Janeiro: Paz e Terra, 1991.

BROTTO, F. O. Pedagogia da Cooperação - para um mundo onde todos podem VenSer. São Paulo: UNIP, 2018. [no prelo]

BURKE, P. A fabricação do rei: a construção da imagem pública de Luis XIV.

(M. X. BORGES, Trad.) Rio de Janeiro: Zahar, 2009.

CAGE, J. 4'33". John Cage - 4'33" by David Tudor. 1952. Disponível em https://www.youtube.com/watch?v=HypmW4Yd7SY\&feature=youtu.be, acesso em 27 de agosto de 2018

CAMARGO, R. C. A pantomima e o teatro de feira na formação do espetáculo teatral: o texto espetacular e o palimpsesto. Fênix - Revista de História e Estudos Culturais, 3, 1-32. Uberlândia: Universidade Federal de Uberlândia, 2006.

CARLSON, M. Teorias do teatro: estudo histórico-crítico, dos gregos à atualidade. (G. C. SOUZA, Trad.) São Paulo: Fundação Editora UNESP, 1997.

CARMO, M. S. "Fedra", de Jean Racine: moral do século XVII e criação literária. Santa Maria: Programa de Pós-Graduação em Letras, 24 (49), 153174. 2014.

CAYUELA, A. De reescritores y reescrituras: teoría y práctica de la reescritura en los paratextos del Siglo de Oro. Toulouse: Criticón, 37-46. 2000.

COELHO, S. S. Um cão andaluz, ou a função do dramaturgista. (J. GUINSBURG, Ed.) São Paulo: Escola de Comunicações e Artes - USP, 2001.

DELEUZE, G. Sobre o teatro: um manifesto de menos; o esgotado. ( $R$. MACHADO, F. SAADI, \& O. ABREU, Trads.) Rio de Janeiro: Jorge Zahar, 2010. 
DIDEROT, D. Discurso sobre a poesia dramática. (F. MATTOS, Trad.) São Paulo: Cosac naify, 2005.

DIDEROT, D. Paradoxo sobre o comediante. (J. G. SILVA, Trad.) São Paulo: Escala, 2006.

DORT, B. O teatro e sua realidade. São Paulo: Perspectiva, 1977.

ELEUTHÉRIO, M. F. A adaptação da História à Tragédia: veracidade e verossimilhança em La Pratique du Théatre, de François Hédélin D'Aubignac. Porto Alegre: Universidade Federal do Rio Grande do Sul, 2013.

ERULLI, B. $O$ ator desencarnado: Marionete e vanguarda. Móin-Móin: Revista de Estudos sobre Teatro de Formas Animadas, 11-25. 2008.

EURÍPEDES. Hipólito. (M. G. KURY, Trad.) São Paulo: Zahar, 2001.

FABIÃO, E. Performance e Precaridade. Em W. d. JÚNIOR (org.), A performance ensaiada: ensaios sobre performance contemporânea (pp. 63-86). Fortaleza: Expressão, 2011.

FACHIN, L. O espaço da narrativa no teatro. Araraquara: Itinerários - Revista de Literatura Seção de Pós-Graduação UNESP - Universidade Estadual Paulista/ Faculdade de Ciências e Letras, n.12, pp. 103-110. 1998.

FERREIRA, A. H. Mini Aurélio: o dicionário da língua portuguesa ( $8^{\mathrm{a}} \mathrm{rev}$. atual. ed.). Curitiba: Positivo, 2010.

FIELD , S. Manual do Roteiro. (Á. RAMOS, Trad.) Rio de Janeiro: Objetiva, 1995. FO, D. Manual Mínimo do Ator. (L. BALDOVINO, \& C. D. SZLAK, Trads.) São Paulo: Senac, 1998.

FONTES, J. B. Hipólito e Fedra: três tragédias/ Eurípedes, Sêneca, Racine. São Paulo: lluminuras, 2007.

FOUCAULT, M. As palavras e as coisas: uma arqueologia das ciências. (S. T. MUCHAIL, Trad.) São Paulo: Martins Fontes, 2016.

FREIRE, P. Pedagogia do Oprimido. Rio de Janeiro: Paz e Terra, 2015.

FUNDAÇÃO VALE. Cadernos de referência de esporte. Pedagogia da Cooperação, 12. Brasília: UNESCO, 2013.

HOBSBAWN, E. A era das revoluções: 1789-1848 (10ª ed.). (M. L. TEIXEIRA, \& M. PENCHEL, Trads.) Rio de Janeiro: Paz e Terra, 2003. 
HUIZINGA, J. Homo ludens. (J. P. MONTEIRO, Trad.) São Paulo: Perspectiva, 2000.

JÚNIOR, C. d. Uma ideia de república em Hippolyte Taine. Anais do XXVI Simpósio Nacional de História, (pp. 1-16). São Paulo: ANPUH - Associação Nacional dos Professores Universitários de História, 2011.

MALHADAS, D. Tragédia grega - o mito em cena. Cotia: Ateliê Editorial, 2003. MARELLI, S. Javier Villafañe: la poesía en mameluco. Ciudad Autónoma de Buenos Aires: Corregidor, 2014.

MATOS, F. A dramaturgia do quadro (Ensaio sobre O Filho Natural de Diderot). Discurso, $\quad$ p. $1996.112 . \quad$ Disponível em http://www.revistas.usp.br/discurso/article/view/38007, acesso em 4 de julho de 2018.

MCKEE, R. Story. (C. Marés, Trad.) Curitiba: Arte \& Letra, 2006.

NEVES, N. A técnica como dispositivo de controle do corpomídia. São Paulo: Programa de Estudos Pós-Graduados em Comunicação e Semiótica - PUC, 2010.

NICOLETE ABREU, A. M. Ateliês de dramaturgia: práticas de escrita a partir da integração artes visuais-texto-cena. (M. d. PUPO, Ed.) São Paulo: Escola de Comunicações e Artes - USP, 2013.

OLIVEIRA, J. Jesus pode ser tudo, menos travesti. São Paulo: El País, 24 de julho de 2018, disponível em: https://brasil.elpais.com/brasil/2018/07/23/cultura/1532371217_501094.html, acesso em 29 de agosto de 2018.

ORLICK, T. Vencendo a competição. (F. G. MARTINS, Trad.) São Paulo: Círculo do Livro, 1993.

PALLOTTINI, R. Dramaturgia - Construção da Personagem. São Paulo: Ática, 1989.

PAVIS, P. Dicionário de Teatro. (J. GUINSBURG, \& M. L. PEREIRA, Trads.) São Paulo: Perspectiva, 2015.

PLATÃO. A República. Rio de Janeiro: Nova Fronteira, 2016.

POCIÑA, A. Motivos de um amor desgraçado: a idade de Fedra e a beleza de Hipólito. Em M. d. SILVA, M. d. FIALHO, \& J. L. BRANDÃO, O livro do tempo: 
escritas e reescritas Teatro Greco-Latino e sua recepção I (pp. 90-102). São Paulo: Imprensa da Universidade de Coimbra Annablume, 2016.

RACINE, J. Phedre \& Hippolyte: tragedie. Paris, Chez Claude Barbin, 1677. Disponível em http://gallica.bnf.fr/ark:/12148/bpt6k70169n/f3.image, acesso em 15 de março de 2018.

RACINE, J. Phèdre ( $2^{\mathrm{a}}$ ed.). (R. PICARD, Ed.) Paris: Gallimard, 2000.

RACINE, J. Fedra. (M. FERNANDES, Trad.) Porto Alegre: L\&PM, 2001.

RACINE, J. Fedra; Ester; Atália. (J. K. SEGALL, Trad.) São Paulo: Martins Fontes, 2005.

RANCIĖRE, J. A partilha do sensível: estética e política. (M. C. NETTO, Trad.) São Paulo: 34, 2009.

RANCIÈRE, J. O Espectador Emancipado. (I. BENEDETTI, Trad.) São Paulo: WMF Martins Fontes, 2012.

RANCIĖRE, J. O mestre ignorante - cinco lições sobre a emancipação intelectual. (L. VALLE, Trad.) Belo Horizonte: Autêntica, 2013.

REWALD, R. Caos Dramaturgia. São Paulo: Perspectiva, 2005.

ROJO, S. Espaço e corpo no teatro italiano atual. Trânsitos e deslocamentos teatrais: da Itália à América Latina, 73 - 121. Rio de Janeiro: 7Letras, 2005.

ROSENFELD, A. O teatro épico. São Paulo: Perspectiva, 1985.

RYKNER, A. O reverso do teatro: dramaturgia do silêncio da idade clássica a Maeterlinck. (D. G. DIAS, Trad.) Lisboa: Fundação Calouste, 2004.

RYNGAERT, J. P. Jogar, representar: práticas dramáticas e formação. (C. R. Silveira, Trad.) São Paulo: Cosac Naify, 2009.

SILVA, F. C. A releitura do mito de Fedra e Hipólito. Niterói: Revista Hélade, 1, 18-23. 2015.

SOLOMON, A. Longe da árvore: pais, filhos e a busca da identidade. (D. GARSCHAGEN, L. ARAÚJO, \& P. M. SOARES, Trads.) São Paulo: Companhia das Letras, 2013.

SOURIAU, E. As duzentas mil situações dramáticas. (M. L. PEREIRA, Trad.) São Paulo: Ática, 1993.

SPOLIN, V. Improvisação para o teatro (6a ed.). (I. D. Koudela, \& E. A. Amos, Trads.) São Paulo: Perspectiva, 2015. 
STANISLAVSKI, C. A construção da personagem. Rio de Janeiro: Civilização Brasileira, 2016.

SZONDI, P. Teoria do drama moderno (1880-1950). (R. I. RODRIGUES, Trad.) São Paulo: Cosac Naify, 2001.

SZONDI, P. Ensaio sobre o trágico. (P. Süssekind, Trad.) Rio de Janeiro: Jorge Zahar, 2004.

SZONDI, P. Teoria do drama burguês [século XVIII]. (L. S. REPA, Trad.) São Paulo: Cosac Naify, 2014.

TYLER, K., \& DRAKE, J. O livro da carta dos anjos. (H. H. RIBEIRO, \& M. BELDA, Trads.) São Paulo: Taygeta, 2011.

UBERSFELD, A. Para ler o teatro. (J. SIMÕES, Trad.) São Paulo: Perspectiva, 2013.

VASQUES, M., \& CUNHA, R. O teatro expandido e a arte permeável de Marcio Abreu. Rio de Janeiro: Questão de Crítica, IX, 281-299. Abril de 2016. Disponível em http://www.questaodecritica.com.br/tag/marcio-abreu/, acesso em 22 de agosto de 2018.

VIEIRA, C. P. "Movimento-imagem-ideia": o percurso de uma prática. (A. d. SILVA, Ed.) Escola de Comunicações e Artes - USP, 2016. 